\title{
FORNECIMENTO DE ÁGUA E NÍVEIS DE POTÁSSIO EM FEIJOEIRO CULTIVADO EM VASOS
}

\author{
RITA CARLA BOEIRA \\ Engenheira Agrônoma
}

Orientador: Prof. Dr. QUIRINO AUGUSTO DE CAMARGO CARMELLO

Tese apresentada à Escola Superior de Agricultura "Luiz de Queiroz", da Universidade de São Paulo, para obtenção do título de Doutor ell Agronomia, Área de Concentração: Solos e Nutriçao de Plantas.

\author{
$P I R A C I C A B A$ \\ Estado de São Paulo - Brasil \\ Novembro - 1994
}


Ficha catalográfica preparada pela Seçăo de Livros da Divisăo de Biblioteca e Documentaçăo - PCLQ/USP

\footnotetext{
Boeira, Rita Carla

H671f Fornecimento de água e níveis de potássio em fei joeiro cultivado em vasos. Piracicaba, 1994. 126p. ilus.

Tese - ESALQ

Bibliografia.

1. Feijăo - Cultivo en vaso 2. Feijă - Estresse hidrico 3. Feijăo - Nutriçăo 4. Potássio em feijăo I. Escola Superior de Agricultura Luiz de Queiroz, Piracicaba
} 


\section{FORNECIMENTO DE ÁGUA E NÍVEIS DE POTÁSSIO EM FEIJOEIRO CULTIVADO EM VASOS}

RITA CARLA BOEIRA

Aprovada em: 19/12/1994

Comissão julgadora:

Prof. Dr. ANTONIO ROQUE DECHEN - ESALQ/USP

Dr. ARIOVALDO LUCHIARI JÚNIOR - CNPMA/EMBRAPA

Dr. EDUARDO ANTONIO BULISANI - IAC

Prof. Dr. GIL MIGUEL DE SOUSA CÂMARA - ESALQ/USP

Prof. Dr. QUIRINO AUGUSTO DE CAMARGO CARMELLO - ESALQ/USP

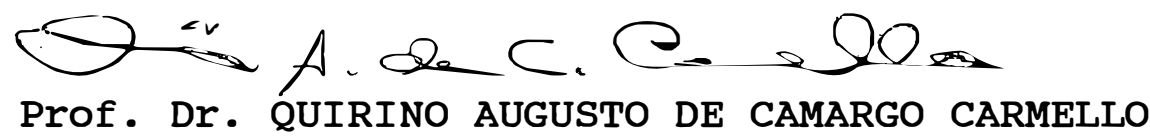

Orientador 
iii.

Ao querido Eric e ao grande amigo Manoel, DEDICO. 
AGRADECIMENTOS

Ao Professor Dr. Quirino Augusto de Camargo Carmello pela orientação deste trabalho.

Ao Professor Dr. Antonio Roque Dechen pelos conhecimentos transmitidos.

Ao Professor Dr. Durval Dourado Neto pelo incentivo à realização do trabalho.

Ao Professor Dr. Klaus Reichardt, por seu exemplo de vida.

À EMBRAPA pela oportunidade.

Ao CNPq pela bolsa de estudos concedida.

Aos Técnicos de Laboratório do setor de Nutrição Mineral de Plantas da ESALQ: Lúcia H.S.P. Forte, Lourdes A.D. de Gonzalez, Mirtes V. Sesso, Ednéia C.S. Mondoni, Nivanda M.A.C. Bovi e Fernando E. Ré, pelo apoio nas análises laboratoriais. 
RESUMO viii

SUMMARY $x i$

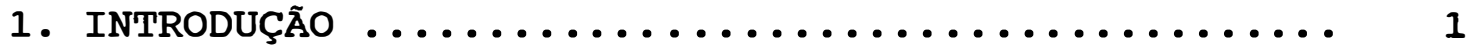

2. REVISÃo DE LITERATURA ..................... 3

2.1. A nutrição potássica na resposta de feijoeiros a deficiência e saturação de água no solo ... 3 2.2. Deficiência hídrica .................. 5

2.3. Encharcamento do solo .................. 9

3. MATERIAL E MÉtodos ........................ 16

3.1. Localização e época do experimento ......... 16

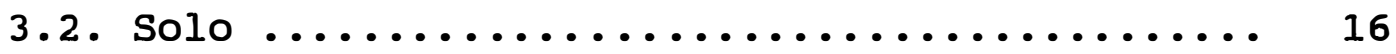

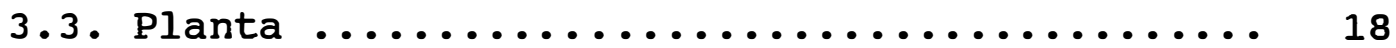

3.4. Práticas culturais ................... 19

3.5. Tratamentos ........................ 20

3.5.1. Regime de água no solo ............ 20

3.5.1.1. Capacidade de campo ........ 21

3.5.1.2. Deficiência hídrica no solo . 21

3.5.1.3. Excesso hídrico no solo ..... 22

3.5.2. Época de aplicação do regime de água no

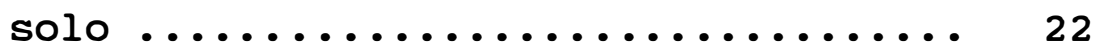

3.5.3. Níveis de potássio .............. 23

3.6. Delineamento experimental .............. 24

3.7. Características avaliadas .............. 24 3.7.1. Duração dos estádios de desenvolvimento 24 
vi.

3.7.2. Lâmina de água aplicada .......... 25

3.7.3. Variação de altura das plantas por estádio de crescimento ............ 25

3.7.4. Número de flores abertas .......... 25

3.7.5. Percentagem de abscisão de flores e vagens pequenas $\ldots \ldots \ldots \ldots \ldots \ldots \ldots \ldots . \ldots . \ldots 26$

3.7.6. Número de vagens ................ 26

3.7.7. Número de sementes por vagem ....... 26

3.7.8. Matéria seca da parte aérea e dos grãos 27

3.7.9. Matéria seca de raízes ........... 27

3.7.10. Teor de $\mathrm{N}, \mathrm{P}, \mathrm{K}, \mathrm{Ca}, \mathrm{Mg}$ e $\mathrm{S}$ nas folhas e grãos ....................... 27

3.8. Análise estatística ................. 28

4. RESULTADOS E DISCUSSÃo ..................... 30

4.1. Temperatura e umidade relativa na casa de vegetação durante o período experimental ..... 30

4.2. Duração dos estádios de desenvolvimento e do

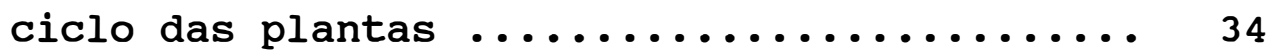

4.3. Lâmina de água aplicada ............... 41

4.4. Altura das plantas ................... 48

4.5. Matéria seca da parte aérea ............. 54

4.6. Matéria seca de raizes ................ 57

4.7. Análise foliar ..................... 58

4.8. Número de flores abertas ............... 72

4.9. Percentagem de abscisão de flores e vagens pequenas $\ldots \ldots \ldots \ldots \ldots \ldots \ldots \ldots \ldots \ldots \ldots \ldots \ldots \ldots . \ldots \ldots$ 
vii.

4.10. Número de vagens ................... 77

4.11. Número de sementes por vagem ........... 81

4.12. Matéria seca dos grãos ................ 81

4.13. Padrão de florescimento e produção ........ 88

4.14. Extração de nutrientes pelos grãos ........ 101

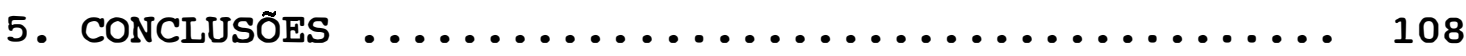

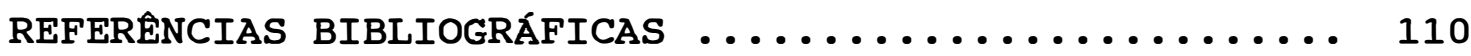


viii.

FORNECIMENTO DE ÁGUA E NÍVEIS DE POTASSIO EM FEIJOEIRO

CULTIVADO EM VASOS

Autora: RITA CARLA BOEIRA

Orientador: PROF. DR. QUIRINO AUGUSTO DE CAMARGO CARMELLO

RESUMO

o presente estudo foi realizado com o objetivo de verificar o efeito da interação entre níveis de potássio aplicados ao solo e estresses hídricos de curta duração aplicados em dois estádios do desenvolvimento reprodutivo do feijoeiro (Phaseolus vulgaris L.) CV. IAC-carioca.

o experimento foi conduzido em casa de vegetação, no Campus da USP, em Piracicaba, SP, Brasil, utilizando-se amostras de um Latossolo Vermelho-Amarelo Álico (Orthic Hapludent), em vasos plásticos $(3,61)$ com três plantas, utilizando-se três regimes de água no solo (capacidade de campo, deficiência hídrica e excesso hídrico) durante cinco dias, em duas épocas (início de pré-floração (R5) e início de formação de vagens (R7)), com quatro níveis de adubação potássica aplicados ao solo $(0,60,120$ e $180 \mathrm{ppm}$ de $\mathrm{K}$ ). Em cada estádio de desenvolvimento das plantas (Vo, V1, V2, V3, V4, R5, R6, R7 e R8), foram avaliados a duração 
ix.

do estádio, a lâmina de água aplicada e o crescimento em altura das plantas.

Nas plantas submetidas ao regime hídrico capacidade de campo, o potássio aplicado ao solo diminuiu a duração do estádio de enchimento de vagens (R8) e do ciclo total. A deficiência hídrica nos estádios R5 e R7 e o excesso hídrico no estádio R5 retardaram a maturação fisiológica das sementes. Os regimes de água afetaram o consumo de água, a altura das plantas, a matéria seca produzida pelas raízes, parte aérea e grãos, o número de flores abertas e de vagens produzidas e a extração de nutrientes pelos grãos.

Houve interação entre os regimes de água e as doses de potássio para a lâmina de água aplicada, a altura das plantas e produção de matéria seca de raízes e parte aérea. A época de aplicação dos tratamentos não afetou a produção de grãos. A dose de potássio aplicada ao solo que proporcionou maior produção de grãos foi em torno de $125 \mathrm{ppm}$, com produções decrescentes para tratamentos sob deficiência hídrica e sob excesso hídrico.

A extração de nutrientes pelos grãos foi maior nos tratamentos em capacidade de campo, seguida dos tratamentos sob deficiência hídrica e sob excesso hídrico, sendo as doses de potássio que causaram maior extração de $\mathrm{N}$, $\mathrm{K}, \mathrm{P}, \mathrm{Ca}, \mathrm{Mg}$ e S variáveis entre 115 e $140 \mathrm{ppm}$.

As doses de potássio afetaram o padrão de florescimento e produção de vagens, com comportamentos 
distintos observados para as duas épocas de aplicação dos regimes de água.

A deficiência hídrica foi mais crítica quando aplicada no início da frutificação (R7) do que no préflorescimnto (R5).

Os melhores parâmetros para avaliar plantas sob estresse hídrico foram $\circ$ número de flores $e \circ$ número de vagens. 
xi.

WATER REGIMES AND POTASSIUM LEVELS APPLIED IN A COMMON BEAN CROP GREENHOUSE EXPERIMENT

Author: RITA CARLA BOEIRA

Adviser: PROF. DR. QUIRINO AUGUSTO DE CAMARGO CARMELLO

SUMMARY

The purpose of this study was to verify the effect of the interaction between potassium levels applied to the soil and the water stress, during two reproductive stages of bean (Phaseolus vulgaris L.) CV. IAC-carioca plants.

The greenhouse experiment was carried out at the University of São Paulo College of Agriculture, in Piracicaba, Brazil. Plastic pots $(3,6$ litres $)$ with three plants each were used. The soil was an Orthic Hapludent.

Three water regimes were applied (field capacity, water deficiency and water excesss), during five days, in two growth stages: pre-flowering (R5) and pod appearance (R7), with four potassium levels $(0,60,120$ and 180ppm). Stage duration, applied water and plant height were evaluated in each stage.

The results showed that the applied potassium reduced the duration of pod filling and period of the total 
xii.

cycle for plants grown at field capacity. Water deficiency in the $\mathrm{R} 5$ and $\mathrm{R} 7$ stages and the water excess in the $\mathrm{R} 5$ retarded fruit maturation.

Water consumption, plant height, root, shoot and grain dry matter, number of opened flowers and grain nutrient extraction, were all affected by the water regimes. There was an interaction between water regimes and potassium levels to plant height and root and shoot dry matter.

The period in which water regimes were applied did not affect grain yield. The highest grain yield was obtained with 125ppm $\mathrm{K}$, being smaller for the water deficiency treatments when compared with the field capacity ones.

Nutrient export through grains was higher for the field capacity treatments, followed by the water deficiency and the water excess. The potassium rates varying from 115 to 140ppm induced higher $\mathrm{N}, \mathrm{K}, \mathrm{P}, \mathrm{Ca}, \mathrm{Mg}$ and $\mathrm{S}$ extractions.

Inflorescence and pod production were affected by the potassium levels, causing different behaviour observed for the two water regimes application times.

The water deficiency treatment was more critical for plants in the R7 stage (pod appearance) than in the R5 stage (pre-flowering).

The number of opened flowers and pods were the best parameters to evaluate plants under water stress. 
1. INTRODUÇÃO

- Brasil é o principal produtor mundial de feijão, com alto índice de consumo per capita. Por isso, a cultura é de grande importância econômica e social. No entanto, as produções brasileiras de feijão não têm aumentado, o que também se verifica na maioria dos países em desenvolvimento dos trópicos e subtrópicos da América, de onde a cultura é originária, bem como na África, Ásia e Austrália. As pesquisas para essas regiões tiveram maior estímulo há cerca de vinte anos e as produtividades de certos materiais a campo mostram a existência de potencial para o aumento da produção.

As localidades brasileiras com destacada participação na produção da cultura de feijão no Brasil localizam-se nas regiões sul, Sudeste e Centro-Oeste, com rendimento médio máximo para o sistema solteiro irrigado $(1.700 \mathrm{~kg} / \mathrm{ha}$ no cultivo de outono/inverno). Nos demais sistemas de cultivo utilizados, sem irrigação, o plantio em geral pode ser feito em duas épocas, no período das águas e no início das secas. No primeiro, as elevadas precipitações colocam em risco a produção, e no segundo, a falta de água 
pode se tornar um grande problema. Além disso, poucas vezes a cultura recebe adubação específica. Em conseqüência, o país mantém baixas produtividades e grandes variações no volume colhido, nem sempre suprindo o mercado interno.

Com base nessa situação, propôs-se o presente projeto com o objetivo de verificar, em feijoeiros, aspectos nutricionais e características agronômicas afetadas pela aplicação de quatro níveis de potássio e manutenção de excesso e deficiência de água no solo, nos estádios de préfloração e pós-floração, em casa de vegetação. 
2.1. A nutrição potássica na resposta de feijoeiros à deficiência e à saturação de água no solo

A quantidade de água na solução do solo afeta - transporte de nutrientes até a superfície radicular, pois afeta a taxa de difusão e o fluxo de massa da água até a raiz. Os íons $\mathrm{Ca}^{++}, \mathrm{Mg}^{++}$, e $\mathrm{NO}_{3}^{-}$são transportados em maior quantidade por fluxo de massa, enquanto $\mathrm{H}_{2} \mathrm{PO}_{4}^{-}$e $\mathrm{K}^{+} \circ$ são pelo mecanismo de difusão. Apesar disso, segundo VIETS JR. (1972), raramente a deficiência mineral é causa de redução do crescimento em plantas com curtos periodos de estresse, pois suas reservas seriam suficientes para suportar esses periodos, principalmente quando à taxa de crescimento é reduzida.

A falta de água no solo pode, no entanto, tornar-se crítica para a disponibilidade de nutrientes às plantas no período de florescimento, quando ocorre acumulação muito rápida de nutrientes e matéria seca em feijoeiros, considerando-se o pequeno sistema radicular da cultura (ROSOLEM, 1992) • 
o potássio, como outros nutrientes, pode afetar o desenvolvimento vegetativo das plantas e, conseqüentemente, a absorção de água. Essa maior demanda por água pode ser maléfica, caso haja pouca disponibilidade hídrica no solo. Além desse efeito, a deficiência de potássio reduz a transpiração (PEASLEE \& MOSS, 1968), afetando os processos fisiológicos do desenvolvimento.

MENGEL \& ARNEKE (1982) verificaram que 0 suprimento inadequado de $\mathrm{K}^{+}$em plântulas de feijoeiro afetou - turgor de folhas novas, inicialmente no tratamento com suprimento insuficiente de potássio, acarretando diferença marcante no crescimento em relação às plântulas com suprimento ótimo. o alto turgor das células meristemáticas é um pré-requisito para a expansão celular e indiretamente também para a divisão celular e o crescimento.

SCHRAVENDIJK \& ANDEL (1985) encontraram algumas respostas fisiológicas à inundação, similares à seca. Uma resposta comum, tanto à seca quanto ao alagamento em plantas, é o fenômeno de fechamento de estômatos, o qual correlacionase diretamente ao fluxo do ín $\mathrm{K}^{+}$nas células guarda, afetando seu turgor através de mudanças osmóticas (SOJKA e STOLZY, 1980).

- cultivo de plantas jovens em solução nutritiva sob condições anaeróbicas, reduziu a absorção de $\mathrm{K}^{+}$ e $\mathrm{NO}_{3}{ }^{-}$, e não afetou a de $\mathrm{Ca}^{++}$; além disso, observou-se um efluxo de $\mathrm{K}^{+}$para a solução (DATTA; 1985). 
A anaerobiose causa a redução da produção de matéria seca, pois a fonte de energia para a absorção iônica pelas raízes tem origem na respiração aeróbica.

A deficiência de oxigênio em plantas, ocasiona um decréscimo na taxa de transpiração, causado em parte pelo fechamento estomatal (GLINSKY \& STEPNIEWSKI, 1986) e, como em geral diminui $\circ$ acúmulo de potássio na parte aérea das plantas, em resposta aos baixos níveis de oxigênio no solo (SOJKA \& STOLZY, 1980), alguns autores levantaram a hipótese de que o nível de potássio afetaria o mecanismo de abertura e fechamento de estômatos em plantas mal oxigenadas.

2.2. Deficiência hídrica

A cultura do feijoeiro é considerada de baixa tolerância à deficiência de água. STONE et al. (1988), cultivando feijoeiros em tensão de água no solo de apenas 250cca, obtiveram decréscimo no desenvolvimento das plantas.

LOPES et al. (1986, 1987) induziram regime hídrico deficiente ininterrupto até o final do ciclo em plantas de feijoeiro a partir de oito dias de idade, em condição de casa de vegetação. Houve redução do ciclo e no número de vagens por planta, sem que tenha havido entretanto acúmulo de matéria seca nas sementes.

Segundo LAWN (1982), as plantas respondem ao estresse de água de diferentes formas. Alteram sua taxa de 
desenvolvimento, que se torna mais rápido ou mais lento; reduzem perdas de água ou aumentam sua absorção, ou podem ainda, possuir mecanismos genéticos de tolerância. Os mecanismos adotados pela planta em resposta ao estresse são variáveis com as condições do mesmo.

Os estudos para se verificar a época na qual as plantas são mais afetadas pela deficiência hídrica, inicialmente foram feitos em fases abrangentes do ciclo da planta. Assim, KATTAN \& FLEMING (1956) avaliaram três períodos de deficiência: a) da semeadura até a abertura da primeira flor; b) florescimento e c) desenvolvimento de vagens. A deficiência hídrica no período vegetativo não afetou a duração do ciclo até a floração. o estresse durante o período de desenvolvimento de vagens foi o tratamento mais prejudicial, diminuindo a produção e o número de vagens por planta, com alta percentagem de vagens mal-formadas. Os autores não detectaram efeitos importantes sobre a produção, do estresse prolongado durante a floração. RAGGI et al. (1972) avaliaram diversos turnos de rega em três fases, e verificaram que o feijoeiro foi mais sensível à deficiência hídrica na fase reprodutiva.

Outros trabalhos confirmaram o pequeno efeito sobre a produção de um estresse hídrico moderado no período vegetativo (MAGALHÃES et al., 1979; MUIRHEAD \& WHITE, 1981; ACOSTA GALLEGOS \& SHIBATA, 1989) •

$$
\text { ROBINS \& DOMINGO (1956) verificaram que a }
$$


deficiência hídrica de 15 dias na pré-floração reduziu a produção, por ter reduzido o número de vagens por área, e retardou a floração em 10 dias, atrasando a maturação. Segundo esses autores, a falta de água no período reprodutivo provocou polinização deficiente e redução do número de vagens e número de grãos por vagem, afetando a produção de sementes, pois a produção do feijoeiro mostrou-se associada aos componentes de produção: número de vagens, número de sementes por vagem e tamanho da semente, conforme relatam LAING et al. (1984), com base em experimentos de manipulação dos fotoassimilados disponíveis. A deficiência de água durante o florescimento pode, ainda, aumentar a abscisão de estruturas reprodutivas, reduzindo o número de vagens maduras (ROBINS \& DOMINGO, 1956). BINKLEY (1932) indicou haver uma relação empírica entre a queda de flores e o suprimento de água.

ARARIPE (1984) estudou o efeito dos níveis de água em vasos, desde o início do florescimento até o final do ciclo, em dois cultivares de feijoeiro, observando efeitos para número de vagens, peso de grãos e número de grãos por vagem. Porém, segundo MAGALHAES et al. (1979), a etapa mais sensível do desenvolvimento ocorre num período mais restrito, entre a floração e o início da formação de grãos.

Em 1969, DUBETZ \& MAHALLE submeteram plantas de feijoeiro a estresses de dez dias, na pré-floração, no florescimento e após o florescimento. Os tratamentos foram escolhidos em função do número de dias após a emergência: 30- 
8.

40, 40-50 e 50-60 dias. Verificaram que o estresse na floração foi o que causou maior redução na produção, seguido pela pré-floração, ambos com redução do número de vagens e atraso de uma semana na colheita.

MAGALHÃES et al. (1979) induziram deficiência hídrica, durante dez dias na pré-floração e durante nove dias no início da frutificação, a campo, atingindo potenciais de água no solo, ao final dos períodos de deficiência, próximos de $-7.000 c c a$ e $-2.700 c c a$, respectivamente, sem obter entretanto, diferenças na produção, entre as duas épocas. No entanto, a deficiência hídrica causou redução na produção, quando comparada ao tratamento sem deficiência, nas duas épocas.

MAGALHÃES \& MILLAR (1978) e SILVEIRA et al. (1981) observaram que a produção em feijoeiros diminui, com - aumento do número de dias com deficiência hídrica no período de floração.

BERGAMASCHI et al. (1988) avaliaram a campo, o efeito de 17 dias de deficiência hídrica no solo. Quando aplicado na formação e desenvolvimento de vagens, as plantas anteciparam sua maturação fisiológica. Quando aplicado na formação de botões florais e floração, o estresse retardou a formação de vagens, o início do enchimento de grãos e a maturação fisiológica, prolongando o ciclo do feijoeiro. Nas duas situações, houve redução no acúmulo de matéria seca.

A deficiência de água altera a natureza e o 
curso de várias reações bioquímicas, o que resulta em mudanças na composição mineral. Em plantas suficientemente estressadas, com transpiração reduzida, pode haver redução na taxa de transporte iônico das raízes aos ramos (KRAMER, 1983).

HEGDE \& SRINIVAS (1990) estudaram a absorção de N, P e K em plantas de feijoeiro submetidas a potenciais de 255cca a -867cca. A absorção de N, P e K foi menor nas irrigações menos freqüentes (menor potencial matricial da água no solo), devido à redução no acúmulo de matéria seca, o que aumentou a concentração de $\mathrm{N}$ e $\mathrm{K}$ nos tecidos.

MUIRHEAD \& WHITE (1981) compararam os tratamentos de irrigação semanal com irrigação quinzenal durante o ciclo completo do feijoeiro, e verificaram que a irrigação mais freqüente diminuiu o teor de $\mathrm{N}$ nas folhas, na época do florescimento, sem afetar, contudo, o teor de $\mathrm{P}$ ou a matéria seca produzida. BENDER et al. (1991) induziram deficiência hídrica no solo durante 14 dias, na antese de feijoeiros, e verificaram que as concentrações de $\mathrm{P}, \mathrm{K}, \mathrm{Mg}$ e S aumentaram nas folhas.

2.3 Encharcamento do solo

$\mathrm{Na}$ grande maioria das culturas de exploração agrícola, o crescimento adequado do sistema radicular demanda grandes quantidades de oxigênio, utilizado na respiração das 
raízes.

o oxigênio se move da atmosfera para o solo, basicamente por difusão através dos poros livres de água. Quando o ar da camada superficial é substituído pela água, a difusão do oxigênio no solo passa a ser desprezível, pois o oxigênio se difunde 10.000 vezes mais rápido no ar do que na água (CLARK \& KEMPER, 1974). Esta pequena taxa de difusão, associada à baixa solubilidade do oxigênio na água, reduz drasticamente o suprimento do mesmo às raízes.

Para comparar a tolerância de várias culturas à aeração deficiente, Tadano et al. $(1979)^{1}$, citados por GLINSKI \& STEPNIEWSKI (1986) calcularam a produção relativa de 18 espécies, desde a mais tolerante (arroz) até espécies pouco tolerantes. O feijão colocou-se em oitavo lugar, com plantas inundadas durante 12 dias apresentando $88 \%$ de produção relativa.

A sensibilidade do feijoeiro à umidade excessiva no solo foi também registrada por LEGARDA \& FORSYTHE (1978) para curtos períodos de saturação, e por FORSYTHE \& PINCHINAT (1971) para encharcamentos de 12 horas de duração repetidos uma vez por semana, durante cinco semanas. SINGH et al. (1991), estudando em casa de vegetação períodos de $0,1,3,5$ e 7 dias de saturação hídrica do solo,

${ }^{1}$ TADANO, T.; KIRIMOTO, K.; AOYAMA, J.; TANAKA, A. Comparison of tolerance to high moisture conditions in the soil among crop plants: studies on the comparative plant nutrition. J. Sci. Soc. Manure, 50:261, 1979 . 
concluíram que em apenas um dia de saturação a fotossíntese foi reduzida, causando decréscimo na produção de matéria seca da planta.

Nos primeiros dias de encharcamento, a respiração radicular é o primeiro processo que se restringe pela deficiência de oxigênio (GLINSKI \& STEPNIEWSKI, 1986). Em conseqüência dos distúrbios respiratórios, outros processos vitais como crescimento e absorção de água e nutrientes são afetados. o crescimento dos ramos em resposta à oxigenação do solo está ligado às respostas das raízes, que em condições de anaerobiose completa, paralisam seu crescimento em 2-3 minutos. Os ramos respondem mais tardiamente e, em geral, as injúrias devidas ao encharcamento desenvolvem-se seqüencialmente, num período de vários dias, tornando-se mais severas com a continuidade do encharcamento. Em plantas com altas taxas de transpiração, o primeiro sintoma de aeração deficiente pode ser a murcha, acompanhada pela redução do crescimento foliar e fechamento estomatal (NEUMAN \& SMIT, 1991), que pode ser resultado do decréscimo de absorção de água causada pelo aumento da resistência das células das raízes à passagem da água. A permeabilidade das raízes é afetada pela idade, pelo estádio de maturação, pela atividade metabólica e por fatores ambientais. Em feijoeiros jovens, DASBERG \& BAKKER (1970) verificaram que a produção de matéria seca e de raízes relacionou-se ao teor médio diário de ar no solo. 
LETEY et al. (1962) estudaram o efeito da duração e da época de aplicação dos tratamentos com deficiência de oxigênio, em plantas no estádio vegetativo, observando uma resposta mais branda nas plantas menos jovens, com sistema radicular mais desenvolvido. SILVA (1982) trabalhando com vasos em casa de vegetação, testou inundações de 2,4 e 6 dias no sistema radicular do feijoeiro, em cinco fases do ciclo vegetativo, sendo as mais sensíveis o início de florescimento e início da frutificação. LAKITAN et al. (1992) observaram redução severa na sobrevivência e produção de feijoeiros sob inundação em estádios reprodutivos, durante quatro dias, considerando que a presença de órgãos reprodutivos per se aumenta o estresse das plantas.

Após um curto período de estresse hídrico, em geral, os estômatos fecham-se, reduzindo parcialmente a perda de água, e as plantas recuperam seu turgor. o controle da abertura estomatal é um dos mais importantes mecanismos regulatórios da planta, determinando a transpiração, o balanço de energia calórica e, provavelmente, também a fotossíntese e a respiração (GLINSKI \& STEPNIEWSKI, 1986). Como explicação para o ajuste estomatal em condições anaeróbicas, além da hipótese da resistência radicular (mecanismo passivo), SOJKA \& STOLZY (1980) sugerem a existência de outros dois mecanismos ativos, sendo que um envolveria substâncias químicas ativas e outro envolveria alterações no fluxo de $\mathrm{K}^{+}$para as células guarda. 
Se o estresse persistir por vários dias, surgem outros sintomas. Epinastia causada pelo aumento de etileno nos ramos é freqüente dentro de 24-48 horas. Em questão de dias até uma semana, as folhas inferiores amarelecem e caem, por desbalanço hormonal ou por problemas de nutrição nitrogenada (DREW \& SISWORA, 1979). Raízes adventícias começam a se desenvolver próximas à linha de água nos caules das plantas em solo saturado (LAKITAN et al., 1992). Aparentemente, as raízes adventícias tomam as funções do sistema radicular que está morrendo, pois plantas que rapidamente desenvolvem raízes adventicias recuperam-se melhor do alagamento (SCHRAVENDIJK \& ANDEL, 1985).

A recuperação dos danos decorrentes de baixas concentrações de oxigênio no solo, depende do tempo de duração dessa situação. HOLDER \& BROWN (1980), estudando a absorção de água em feijoeiros estressados, não observaram recuperação completa, em alguns casos, até cinco dias após cessado o tratamento.

Com relação ao efeito do encharcamento sobre a produção, LAKITAN \& WOLFE ( 1988 ) inundaram feijoeiros durante quatro dias em cinco épocas $(20,24,28,32$ e 36 dias após o plantio). O tratamento aplicado 20 e 24 dias após o plantio atrasou a maturação, sem diminuir o número de vagens por planta ou a produção.

A aeração deficiente pode reduzir a absorção de nutrientes e produzir sintomas de deficiência. DREW (1977) e 
DREW \& SISWORA (1979) sugerem que a principal causa dos sintomas de injúria ao encharcamento seja um distúrbio no metabolismo do $\mathrm{N}$.

Segundo GLINSKI \& STEPNIEWSKI (1986) as mudanças na absorção de nutrientes são geralmente observadas antes das variações na composição da planta, pois estão ligadas a um decréscimo visível na massa da planta, enquanto que mudanças na composição mineral aparecem somente em condições mais drásticas ou mais prolongadas de estresse.

O teor de $\mathbf{N}$ nas plantas pode aumentar ou diminuir, conforme as espécies e os estádios de desenvolvimento em que o estresse é aplicado. Se a absorção cessa e o crescimento continua, o teor é diminuído pelo efeito de diluição. A absorção de $\mathrm{N}$ é menor sob estresse de oxigênio em relação às plantas não estressadas, e isto é acompanhado por um decréscimo na massa e na produção das plantas em condições anóxicas, havendo também decréscimo na absorção de $\mathrm{P}$ por plantas estressadas. O teor nas várias partes (raízes, parte aérea, caule, folhas, grãos) decresce ou permanece inalterado. Como no caso do $\mathrm{N}$, há um decréscimo nas folhas velhas e aumento nas folhas novas, pelo deslocamento do $\mathrm{P}$, já que a absorção praticamente cessa enquanto o crescimento apenas diminui (GLINSKI \& STEPNIEWSKI, $1986)$.

Plantas sob anaerobiose do solo apresentam decréscimo no teor de $\mathrm{K}$ em suas várias partes e uma menor 
absorção. Alguns autores concluíram que $\mathrm{K}$ é $\mathrm{o}$ nutriente mais sensivel à deficiência de oxigênio no ambiente radicular. Isto significa que, uma diminuição no seu teor é perceptivel antes e mais distintamente que de outros ions, resultando em um decréscimo na razão $\mathrm{K} /(\mathrm{Ca}+\mathrm{Mg})$. o teor de Ca e Mg nas plantas parece ser menos dependente da anaerobiose do solo do que os de $\mathrm{N}, \mathrm{P}$ e $\mathrm{K}$ (GLINSKI \& STEPNIEWSKI, 1986 ). 
3.1. Localização e época do experimento

o experimento foi conduzido em casa de vegetação no Departamento de Química da ESALQ, no Campus da USP, em Piracicaba, SP, no período de 19/07/93 a 04/1/93.

\section{2 . Solo}

o solo utilizado foi descrito e classificado por RANZANI et al. (1966) e é pertencente à série Sertãozinho, Latossolo Vermelho-Amarelo Álico, A moderado (Orthic Hapludent). Foi coletado da camada 0 a $15 \mathrm{~cm}$ de profundidade, colocado a secar ao ar livre, destorroado e passado em peneira de $4 \mathrm{~mm}$.

Os resultados da análise granulométrica do solo, feita pelo método do densímetro (KIEHL, 1979) e da análise química segundo metodologia descrita por RAIJ \& QUAGGIO (1983) encontram-se na Tabela 1.

Para obter-se a curva característica de retenção de solução do solo, utilizaram-se amostras 
deformadas $\left(\rho_{\mathrm{g}}=1,39 \mathrm{~g} / \mathrm{cm}^{3}\right.$, média das massas específicas do solo no local de coleta nas profundidades $0-7,5 \mathrm{~cm} \mathrm{e} 7,5-15,0 \mathrm{~cm}$ ), colocadas em mesa de tensão para a determinação dos potenciais de $0,-10,-20,-40,-60$ e $-100 \mathrm{cca}$, e em câmara de Richards para potenciais de -3.000 e $-15.000 c c a$. A relação funcional entre a umidade à base de volume $\theta$ (teta) ( $\mathrm{cm}^{3}$ de água $/ \mathrm{cm}^{3}$ de solo) e o módulo do potencial matricial foi obtida segundo o modelo de GENUCHTEN (1980), através de regressão não linear (método dos quadrados mínimos), utilizando-se o programa computacional Curvaret (DOURADO NETO \& JONG-van-LIER, 1992) e obtendo-se a curva da Figura 1.

Tabela 1. Análise química e granulométrica do solo utilizado no experimento.

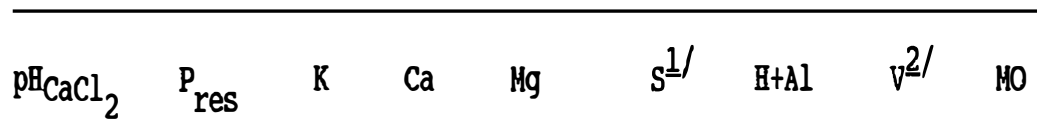

\begin{tabular}{|c|c|c|c|c|c|c|c|}
\hline \multirow[b]{2}{*}{4,75} & \multirow{2}{*}{$\begin{array}{r}\mu \mathrm{g} / \mathrm{cm}^{3} \\
3,5\end{array}$} & \multicolumn{4}{|c|}{---.---- meq/100cm ${ }^{3}$} & \multicolumn{2}{|c|}{----- $\div$----- } \\
\hline & & $0,05 \quad 2,04$ & 0,56 & 2,7 & 3,81 & 41,0 & 2,26 \\
\hline \multicolumn{2}{|c|}{ argila } & silte & areia & & \multicolumn{2}{|c|}{ areia grossa } & \\
\hline \multicolumn{2}{|c|}{22} & 12 & 3 & & \multicolumn{2}{|c|}{32} & \\
\hline
\end{tabular}




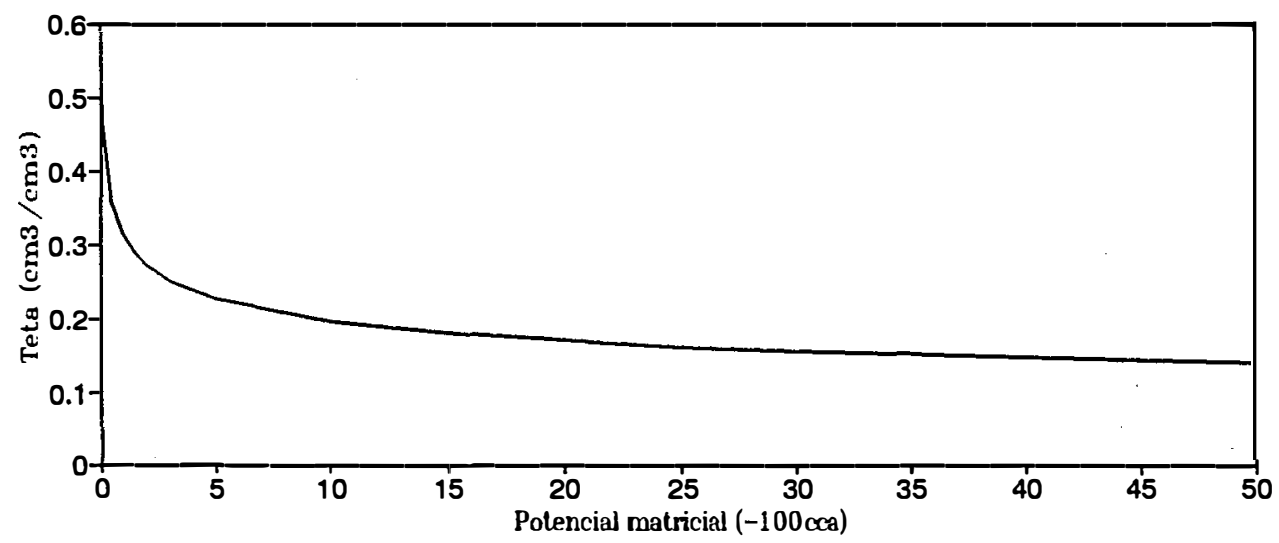

Figura 1. Curva de retenção da solução do solo para amostra deformada com $\rho_{\mathrm{g}}=1,39 \mathrm{~g} / \mathrm{cm}^{3}$.

3.3. Planta

Foram utilizadas sementes genéticas de feijoeiro (Phaseolus vulgaris L.) CV. IAC-carioca fornecidas pela Seção de Leguminosas do IAC, que segundo SILVA (1981) possui as seguintes caracteristicas: porte semi-prostrado, hábito de crescimento indeterminado tipo 3, podendo comportar-se com hábito intermediário entre tipo 2 (ereto) e tipo 3 (prostrado ou com tendência a trepador), 30-35 dias para floração, flores brancas, 60-65 dias para o início da maturação, ciclo vegetativo até a maturação de colheita de 85 dias, semente cor bege com rajas havana, pertencente ao grupo comercial Mulatinho Rajado. 
3.4. Práticas culturais

Utilizou-se vasos plásticos $(15 \mathrm{~cm}$ de altura e diâmetro de $17 \mathrm{~cm}$ ) revestidos com sacos de polietileno. A terra a ser colocada no vaso foi pesada ( $3.910 \mathrm{~g}$ de massa de terra seca ao ar) e homogeneizada em saco plástico com 2,56g por vaso de $\mathrm{CaCO}_{3}, 0,54 \mathrm{~g}$ por vaso de $\mathrm{MgCO}_{3}$ e $\mathrm{Ca}\left(\mathrm{H}_{2} \mathrm{PO}_{4}\right)_{2} \cdot \mathrm{H}_{2} \mathrm{O}$ (relação molar 4:1 de $\mathrm{CaCO}_{3}$ e $\mathrm{MgCO}_{3}$ ). A calagem foi feita visando-se elevar a saturação de bases do solo a 70\%, conforme recomendação de RAIJ et al. (1985). A seguir, o vaso foi preparado compactando-se a terra em quatro camadas para que atingisse a mesma massa específica do solo no local onde foi coletada. Em seguida, os vasos foram irrigados até atingirem o teor de água da capacidade de campo, e deixados em incubação durante uma semana.

A semeadura foi feita em $19 / 07 / 93$, a $2 \mathrm{~cm}$ de profundidade, utilizando-se nove sementes por vaso. 0 desbaste foi feito em $31 / 07 / 93$ (as plantas encontravam-se no estádio V2 deixando-se três plantas uniformemente desenvolvidas por vaso, conduzidas com um tutor por vaso. Os tratamentos fitossanitários foram preventivos e seguiram as recomendações de VENDRAMIM (1992), SARTORATO (1992) e SARTORATO et al. (1981). Semanalmente, a partir do estádio V3, foram feitas aplicações de metamidofós e mancozeb (em dias distintos) até o estádio de préflorescimento (R5), visando o controle de ácaros, ferrugem e 
mancha angular, que ocorreram em baixa intensidade.

o controle da irrigação foi feito diariamente até a maturação dos grãos, visando-se obter o teor de água no solo da capacidade de campo, determinado conforme será descrito no item 3.5.1.1.

Durante o período experimental, a temperatura e a umidade foram registradas em um termohigrógrafo, instalado na mesma altura das plantas. Os valores médios diários foram obtidos pela média aritmética de 12 observações por dia, tomadas de duas em duas horas.

A adubação dos vasos constou de 150ppm (base em massa de solo seco) de fósforo (P) aplicadas no preparo dos vasos na forma de $\mathrm{Ca}\left(\mathrm{H}_{2} \mathrm{PO}_{4}\right)_{2} \cdot \mathrm{H}_{2} \mathrm{O} ; 7 \mathrm{ppm}$ de enxofre (S) aplicadas cinco dias após a emergência (DAE) na forma de $\left(\mathrm{NH}_{4}\right)_{2} \mathrm{SO}_{4} ; 20 \mathrm{ppm}$ de magnésio $(\mathrm{Mg})$ aplicadas no estádio R5 como $\mathrm{MgSO}_{4} \cdot 7 \mathrm{H}_{2} \mathrm{O}$, e $220 \mathrm{ppm}$ de nitrogênio (N) parceladas em doses de 15ppm aos cinco DAE, 105ppm no estádio V4, 60 ppm no estádio R5 e 40ppm no estádio R6, tendo como fonte uréia e descontado o $\mathrm{N}$ contido no sulfato de amônio utilizado para fornecer S. As plantas não foram inoculadas com Rhizobium phaseoli.

3.5. Tratamentos

3.5.1. Regime de água no solo 
Foram estudados três regimes de água no solo, a saber: capacidade de campo, deficiência e excesso.

\subsubsection{Capacidade de campo}

Neste nível de água no solo, as plantas foram irrigadas diariamente, visando-se obter o teor de água da capacidade de campo.

Para a determinação deste teor, utilizou-se o método denominado TSFM (torrão separado pela frente de molhamento) (CosTA, 1983), que simula o princípio da capacidade de campo, e é descrito a seguir.

$$
\text { Colocou-se } 150 \mathrm{~g} \text { da amostra de terra numa }
$$
cápsula de alumínio e, com uma pipeta, adicionou-se $2 \mathrm{ml}$ de água destilada. Após 10 segundos, retirou-se o torrão úmido (separado da terra seca pela frente de molhamento), que foi imediatamente pesado, obtendo-se o peso úmido. o teor de água do torrão foi determinado por gravimetria. Calculou-se então a quantidade de água necessária para a terra do vaso atingir o mesmo teor de umidade do torrão úmido.

o potencial matricial estimado da água no solo em capacidade de campo foi de aproximadamente -100cca (Figura 1).

3.5.1.2. Deficiência hídrica no solo 
Neste tratamento, as irrigações foram suspensas por cinco dias e após o estresse, os vasos foram irrigados e mantidos em capacidade de campo.

\subsubsection{Excesso hídrico no solo}

Neste tratamento, o solo foi mantido saturado durante cinco dias, com uma lâmina de aproximadamente $0,5 \mathrm{~cm}$. A água foi colocada pouco a pouco nos vasos, durante o primeiro dia, para permitir a saída de ar do solo. Diariamente, completou-se o vaso com água até que atingisse o peso do primeiro dia, ou seja, o peso do solo saturado com água mais a lâmina de água.

Ao final do tratamento, o excesso de água foi drenado através de furos na base dos vasos, e os vasos voltaram a ser irrigados até a capacidade de campo.

3.5.2. Época de aplicação do regime de água no solo

Os níveis de água no solo foram aplicados em duas épocas: início do estádio R5 (tratamento denominado Época R5) e início do estádio R7 (tratamento denominado Época R7); estádios definidos em CENTRO INTERNACIONAL DE AGRICULTURA TROPICAL (1983) (tabela 2). 
Tabela 2. Etapas do desenvolvimento da planta de feijão (CENTRO INTERNACIONAL DE AGRICULTURA TROPICAL, 1983 ) .

\begin{tabular}{lcc}
\hline Fase & $\begin{array}{c}\text { Código da } \\
\text { etapa }\end{array}$ & Etapa \\
\hline V0 & V1 & Germinação \\
Vegetativa & V2 & Folhergência \\
& V3 & primárias desdobradas \\
& V4 & folha trifoliolada \\
& desdobrada \\
& R5 & $3^{\text {a. }}$ folha trifoliolada \\
R6 & desdobrada \\
\hline Reprodutiva & R7 & Pré-floração \\
& R8 & Floração \\
& R9 & Formação de vagens \\
& & Enchimento de vagens \\
& & Maturação
\end{tabular}

3.5.3. Níveis de potássio

Foram aplicados quatro níveis de potássio: 0, 60, 120 e 180ppm do nutriente (base em massa de solo seco), utilizando-se $\mathrm{KCl}$ como fonte. Cada nível foi parcelado em três vezes: $30 \%$ foi aplicado no estádio vo (cinco DAE), 40\% no início do estádio V4 (32 DAE) e 30\% no estádio R6 (47 DAE ) . 
As aplicações foram feitas pipetando-se solução diluída de $\mathrm{KCl}$ sobre o solo do vaso, imediatamente antes das irrigações.

3.6. Delineamento experimental

Os fatores e niveis que constituiram os tratamentos foram combinados em esquema fatorial $2 \times 3 \times 4$. Os tratamentos foram alocados às unidades experimentais conforme o delineamento de blocos ao acaso, com quatro repetições. A unidade experimental foi o vaso, com três plantas.

3.7. Características avaliadas

3.7.1. Duração dos estádios de desenvolvimento

Os estádios de desenvolvimento considerados foram os definidos na Tabela 2 (CENTRO INTERNACIONAL DE AGRICULTURA TROPICAL, 1983) e descritos também em FANCELLI (1992). Em cada unidade experimental, o início de cada estádio foi considerado quando duas plantas alcançaram o desenvolvimento característico. As observações destas caracteristicas foram feitas diariamente. 
3.7.2. Lâmina de água aplicada

A irrigação dos vasos foi feita diariamente medindo-se o volume de água adicionado através da pesagem individual das unidades experimentais. Este volume foi então transformado em lâmina de água aplicada (mm) .

\author{
3.7.3. Variação de altura das plantas por estádio \\ de crescimento
}

A altura média das plantas em cada vaso foi medida em intervalos semanais e expressa pelo comprimento da haste principal. A variação foi obtida pelo crescimento em centímetros observado entre o início de um estádio e o início do estádio seguinte.

3.7.4. Número de flores abertas

O número de flores abertas foi avaliado em cada planta pela contagem e etiquetagem de todas as flores abertas, diariamente, desde o início até o final da floração. Foram utilizadas etiquetas de joalheria onde foi inscrita a data da abertura de cada flor. 
3.7.5. Percentagem de abscisão de flores e vagens pequenas

A percentagem de abscisão por planta ( $F \%$ ) foi determinada segundo PORTES (1981), através da equação:

$$
F(\%)=\frac{\left(n^{\circ} \text { de flores abertas }\right)-\left(n^{\circ} \text { total de vagens }\right)}{n^{\circ} \text { de flores abertas }}
$$

3.7.6. Número de vagens

o número de vagens cheias e chochas por planta foi obtido por contagem das vagens, à medida que atingiam o ponto de colheita (vagens secas ao tato).

A percentagem de vagens chochas foi obtida dividindo-se o número de vagens chochas pelo número total de vagens produzidas.

3.7.7. Número de sementes' por vagem

Foi obtido somando-se o número total de sementes e dividindo-se pelo número total de vagens maduras, excluindo-se as vagens chochas. 
3.7.8. Matéria seca da parte aérea e dos grãos

Para obtenção da matéria seca da parte aérea, as plantas foram cortadas rente ao solo ao final da colheita das vagens, sendo folhas, vagens (sem os grãos), caules e pecíolos colocados em sacos de papel. Os grãos foram embalados em separado. o material foi seco em estufa com circulação forçada de ar a $60^{\circ} \mathrm{C}$ até massa constante e a massa de matéria seca foi determinada em balança eletrônica digital com leitura em centigramas.

A massa do material seco de 100 sementes foi estimada a partir da massa do material seco das sementes produzidas.

\subsubsection{Matéria seca de raízes}

Ao final do experimento, o sistema radicular foi lavado sobre peneira de $0,5 \mathrm{~mm}$ até a eliminação total do solo aderido às raízes, e foram secas em estufa $\left(60^{\circ} \mathrm{C}\right)$ até massa constante.

3.7.10. Teor de $\mathrm{N}, \mathrm{P}, \mathrm{K}, \mathrm{Ca}, \mathrm{Mg}$ e $\mathrm{S}$ nas folhas $\mathrm{e}$ grãos

Em cada unidade experimental, as folhas foram coletadas no início e no fim de cađą época de aplicação da 
lâmina de água (R5 e R7), utilizando-se a terceira ou quarta folha aberta, contada a partir do ápice da haste principal, sem pecíolos, e obtendo-se, em cada repetição, amostras compostas por tratamentos iguais. Após secagem em estufa, as folhas e os grãos foram moídos em moinho de facas com peneira de $0,2 \mathrm{~mm}$ e embalados em sacos de polietileno para posterior análise. Determinou-se N, P, K, Ca, Mg e S conforme a metodologia descrita por SARRUGE \& HAAG (1974).

\subsection{Análise estatística}

Para verificar a significância das diferenças obtidas entre os tratamentos, procedeu-se à análise de variância dos resultados, conforme o modelo de blocos casualizados através do teste $F$ ao nível de $5 \%$ de probabilidade.

Para análise dos dados referentes aos teores de nutrientes nas folhas, foi empregada a análise de variância conforme $o$ modelo de parcelas subdivididas no tempo, considerando-se o fator época de coleta das folhas como subparcela.

Para a comparação entre médias, utilizou-se o teste de Duncan, ao nível de 5\% de probabilidade. Para maior detalhamento, utilizou-se a análise de regressão polinomial das variáveis para os níveis de potássio aplicados ao solo. As variáveis número de vagens maduras, dụração 
dos estádios R6 e R7, número de sementes por vagem e extração de nutrientes foram transformados para $\sqrt{(x+1)}$ onde " $x$ " é a variável original; número de flores abertas, duração dos estádios R5 e R8 e duração do ciclo total, para $\sqrt{x} ; F(\%)$ e percentagem de vagens chochas para arco-seno $\sqrt{(x / \overline{100)} \text { e a }}$ variação de altura no estádio $R 8$ e a massa seca de 100 sementes, para $\log (x+1)$. 
4.1. Temperatura e umidade relativa na casa de vegetação durante $o$ periodo experimental

Com os resultados diários registrados no termohigrógrafo, calculou-se as temperaturas e umidades relativas médias, máximas e mínimas no período experimental, as quais encontram-se nas Figuras 2 e 3 . Observa-se que houve acentuada variação nos regimes de temperatura e umidade relativa do ar na casa de vegetação durante a condução do experimento.

Durante todo o período vegetativo (V0 a V4) e no início do estádio $\mathrm{R} 5$, de julho a agosto, foram registradas umidades relativas muito baixas durante o dia, acompanhadas de elevadas temperaturas máximas. Em muitos dias, nas horas mais quentes e ensolaradas ocorreram murchas mesmo em plantas do tratamento com solo na capacidade de campo, as quais recuperavam seu turgor ao final do dia. TURNER \& BEGG (1981) descrevem este desenvolvimento da deficiência de água em plantas durante a manhã com posterior recuperação à tarde, considerando os gradientes de potencial da água que se 


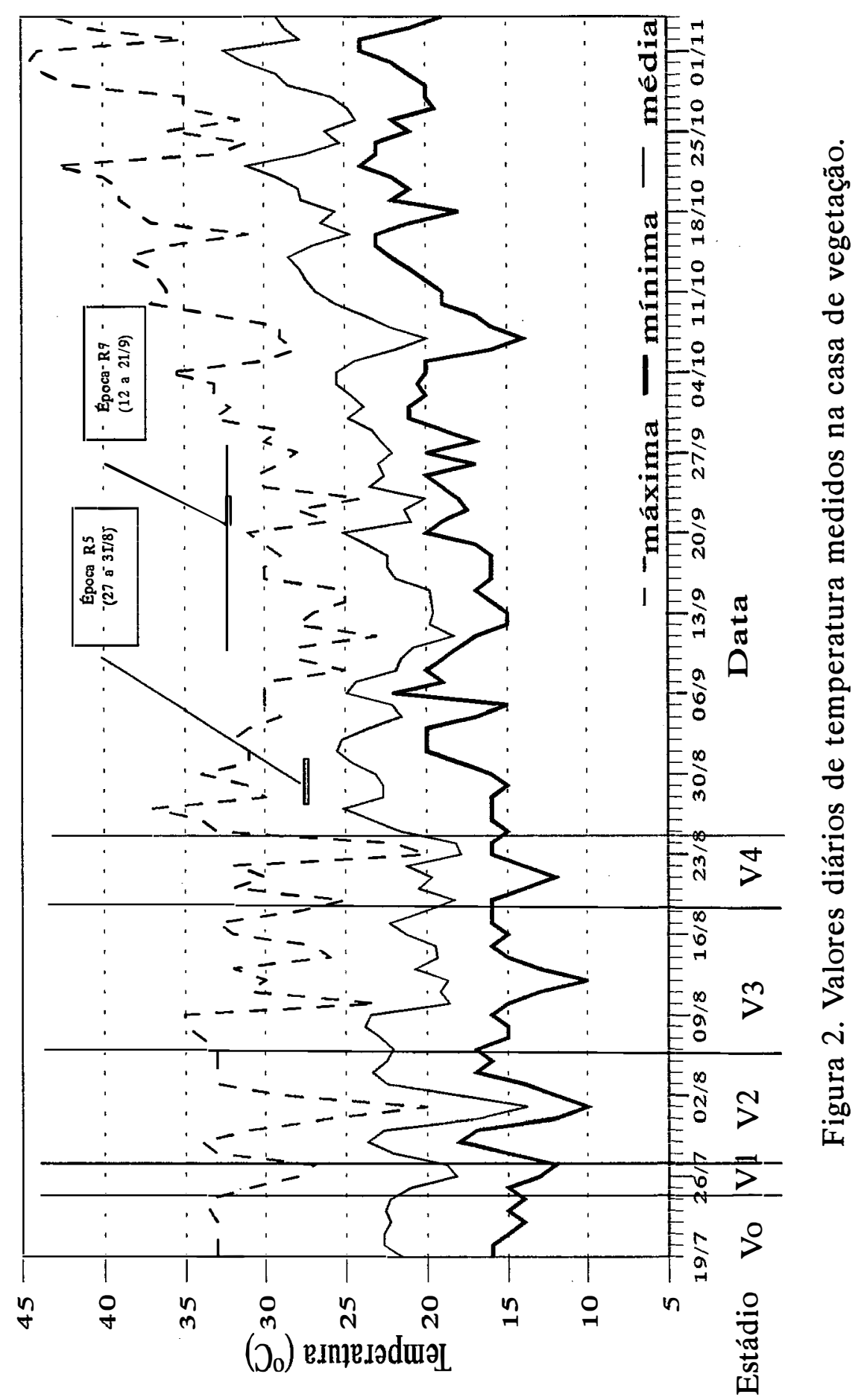




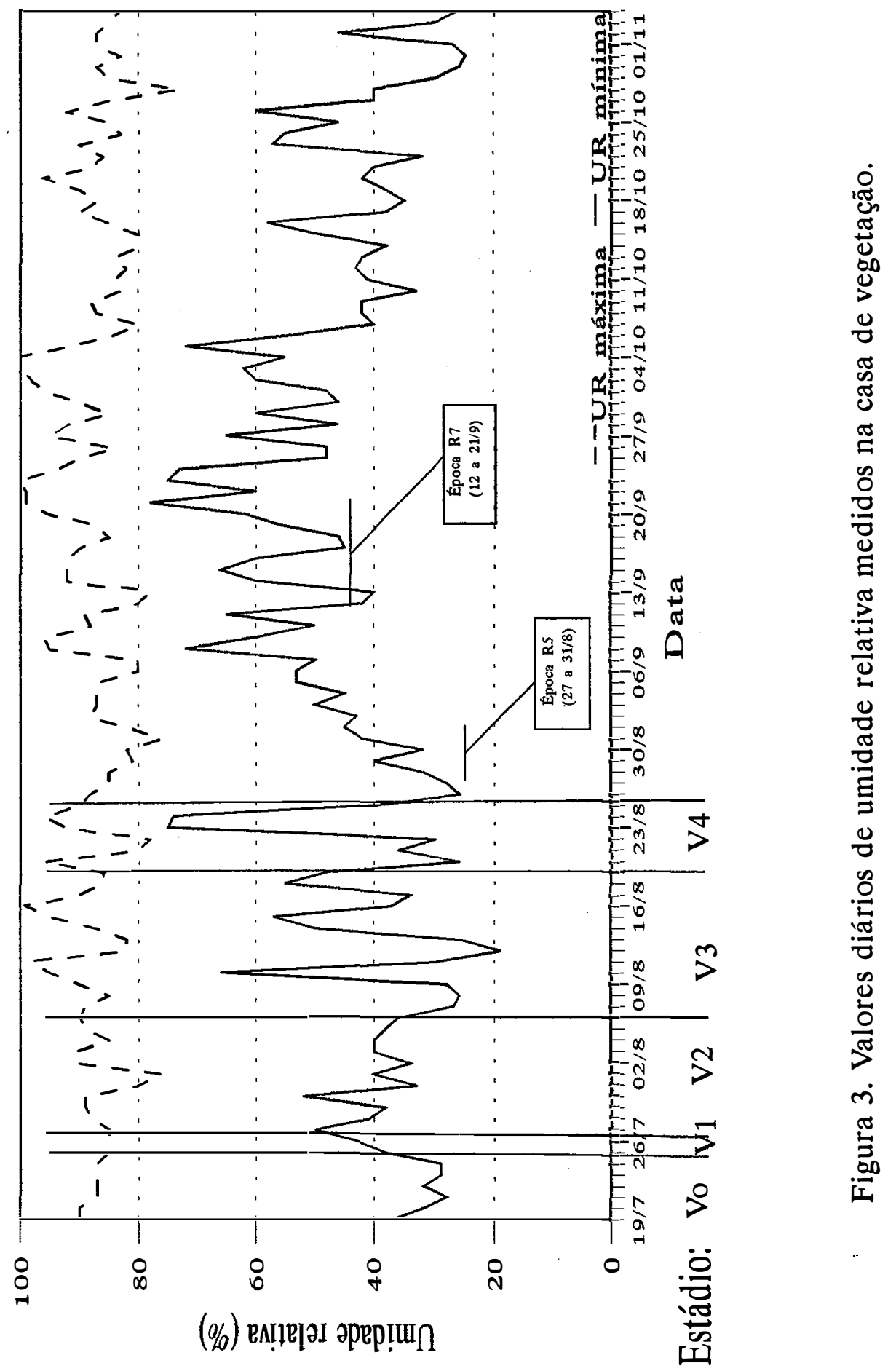


estabelecem entre a planta e o solo como dependentes da demanda evaporativa do ambiente e da resistência do solo e da planta ao fluxo de água.

A baixa umidade relativa induz alta demanda evapo-transpirativa, com aumento na tensão de água na planta, e o solo pode atingir valores baixos de condutividade hidráulica, o que torna a água do solo menos disponível às raízes. LAKITAN (1990) relata que o estresse em feijoeiros sob deficiência de oxigênio no solo foi intensificado em condições de elevada demanda evaporativa. Em resposta ao tratamento de deficiência hídrica no solo na época R5, as plantas mostraram movimentos násticos para-heliotrópicos como foi observado também por DUBETZ (1969) e BERGAMASCHI et al. (1988).

Segundo TURNER \& BEGG (1981) e LAWN (1982), mudanças na orientação das folhas visam reduzir a radiação incidente sobre elas, permitindo à planta menor dissipação de energia. Os mecanismos que determinam estas mudanças atuam somente durante periodos de estresse, sem afetarem irreversivelmente a área foliar. No entanto, a ocorrência de elevadas temperaturas associadas às baixas umidades relativas durante o dia, no período de $27 / 8$ a $31 / 8$ (figuras 2 e 3) induziu ao secamento total de algumas folhas.

A partir do estádio R5, manteve-se uma lâmina de água no piso da casa de vegetação durante o período diurno, com as janelas fechadas. Assim os ventiladores 
passaram a introduzir ar úmido no recinto, visando aumentar a umidade relativa e diminuir a demanda evaporativa. Sobre os dois blocos experimentais mais atingidos pela radiação solar foi instalada uma tela sombrite, pois o sombreamento diminui, em parte, o efeito da deficiência hídrica, por reduzir a transpiração (LOPES et al., 1986). Com isso, conseguiu-se amenizar as condições ambientais do experimento no restante do período de pré-floração (R5) até pouco antes do início da maturação fisiológica, na maior parte dos tratamentos, em relação ao ambiente externo, que se apresentava muito seco e quente (tabela 3 ).

Do início de outubro até o final do experimento, as temperaturas foram aumentando desde $30^{\circ} \mathrm{C}$ até quase $45^{\circ} \mathrm{C}$, e a umidade relativa manteve-se, em geral, abaixo de $50 \%$

Na segunda época de aplicação de tratamentos (época R7), houve condições ambientais mais amenas e, nos tratamentos de deficiência, o secamento do solo foi mais gradual, como se vê na Figura 4 .

4.2. Duração dos estádios de desenvolvimento e do ciclo das plantas

A duração dos estádios $V_{0}, V 1, V 2, V 3$ e V4 foi de $7,2,10,13$ e 6 dias, respectivamente.

As plantas tiveram desenvolvimento uniforme 
Tabela 3. Temperatura $\left({ }^{\circ} \mathrm{C}\right)$ e umidade relativa (\%) dentro e fora da casa de vegetação entre 31/8/93 e $28 / 9 / 93$.

\begin{tabular}{|c|c|c|c|c|c|}
\hline \multirow[b]{2}{*}{ Data } & \multirow[b]{2}{*}{ Hora } & \multicolumn{2}{|c|}{ Leituras externas } & \multicolumn{2}{|c|}{ Leituras do termohigrografo } \\
\hline & & $\mathrm{T}\left({ }^{\circ} \mathrm{C}\right)$ & UR (\%) & $\mathrm{T}\left({ }^{\circ} \mathrm{C}\right)$ & UR (\%) \\
\hline \multirow[t]{5}{*}{$31 / 8$} & $11: 00$ & 29,4 & 48 & 30,0 & 60 \\
\hline & $12: 00$ & 30,7 & 47 & 30,0 & 58 \\
\hline & $14: 00$ & 34,4 & 38 & 32,0 & 53 \\
\hline & $15: 00$ & 34,4 & 38 & 31,0 & 51 \\
\hline & $16: 00$ & 33,3 & 40 & 30,5 & 48 \\
\hline $01 / 9$ & $13: 30$ & 31,6 & 51 & 30,0 & 63 \\
\hline \multirow[t]{2}{*}{$06 / 9$} & $16: 00$ & 32,3 & 52 & 29,0 & 58 \\
\hline & $17: 00$ & 30,0 & 54 & 26,0 & 69 \\
\hline \multirow[t]{3}{*}{$07 / 9$} & $9: 00$ & 24,4 & 70 & 24,5 & 74 \\
\hline & $11: 00$ & 32,8 & 62 & 28,0 & 69 \\
\hline & $15: 00$ & 30,0 & 60 & 30,0 & 55 \\
\hline \multirow[t]{4}{*}{$18 / 9$} & $10: 30$ & 24,4 & 55 & 28,0 & 65 \\
\hline & $12: 00$ & 26,7 & 47 & 28,0 & 62 \\
\hline & $16: 00$ & 28,6 & 38 & 27,0 & 64 \\
\hline & $17: 00$ & 27,8 & 45 & 26,5 & 63 \\
\hline \multirow[t]{3}{*}{$19 / 9$} & $11: 00$ & 30,6 & 48 & 29,0 & 69 \\
\hline & $13: 00$ & 32,5 & 42 & 30,0 & 65 \\
\hline & $14: 00$ & 33,0 & 44 & 30,0 & 68 \\
\hline \multirow[t]{2}{*}{$20 / 9$} & $15: 00$ & 33,9 & 40 & 31,0 & 65 \\
\hline & $16: 00$ & 32,8 & 45 & 29,0 & 65 \\
\hline \multirow[t]{2}{*}{$21 / 9$} & $15: 00$ & 26,6 & 58 & 27,5 & 70 \\
\hline & $16: 00$ & 25,0 & 66 & 26,0 & 65 \\
\hline \multirow[t]{3}{*}{$28 / 9$} & $14: 30$ & 26,7 & 44 & 28,5 & 58 \\
\hline & $15: 30$ & 26,7 & 46 & 28,0 & 58 \\
\hline & $16: 15$ & 26,7 & 46 & 27,5 & 58 \\
\hline
\end{tabular}




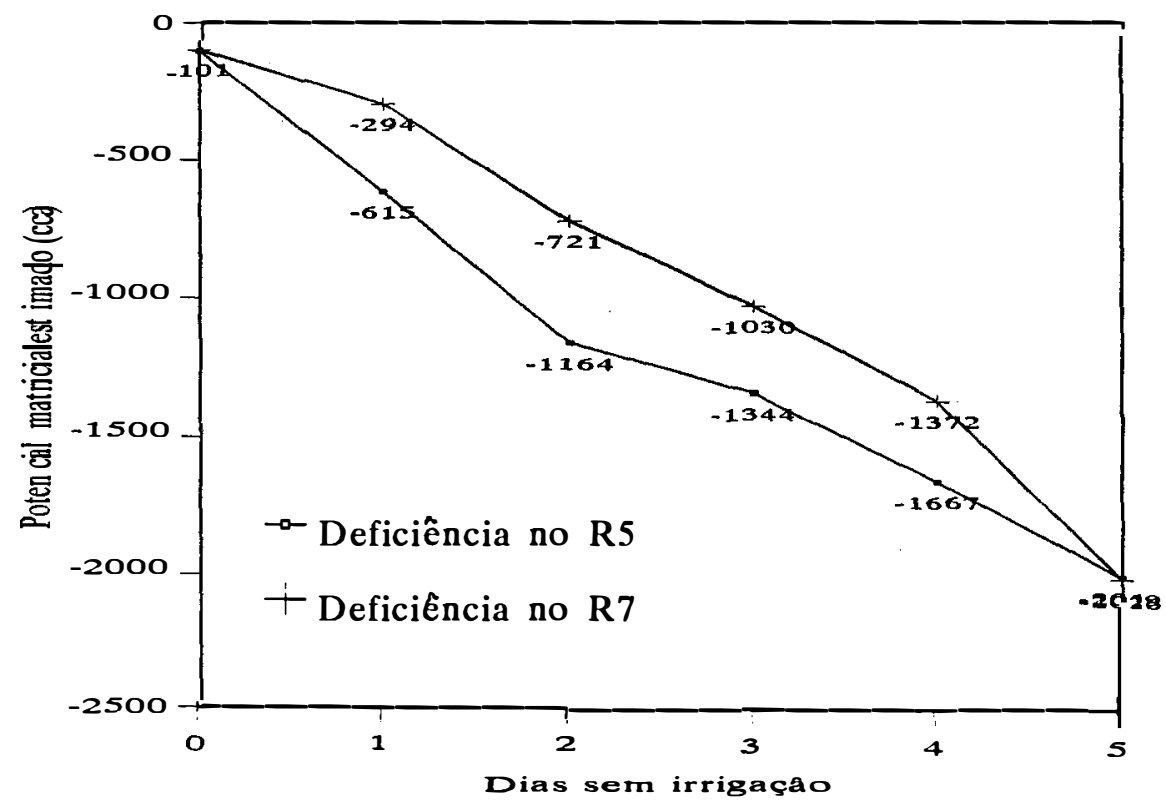

Figura 4. Potencial matricial estimado (cca) da água no solo dos vasos durante o. secamento nos tratamentos com deficiência hídrica nos estádios R5 e R7 (Médias de 16 repetições).

nestas cinco etapas da fase vegetativa, que teve duração total de 38 dias. Não houve efeito visivel do potássio na vegetação das plantas.

$\mathrm{Na}$ fase reprodutiva, houve diferenças significativas na duração dos estádios.

Nas Tabelas 4, 5, 6 e 7 são apresentados os resultados referentes à duração dos estádios R5 e R6, R7, R8 e do ciclo total, respectivamente. A duração do estádio R9 não foi considerada dada a desuniformidade de maturação das vagens. 
Tabela 4. Duração em dias dos estádios R5 e R6 (média de quatro repetições).

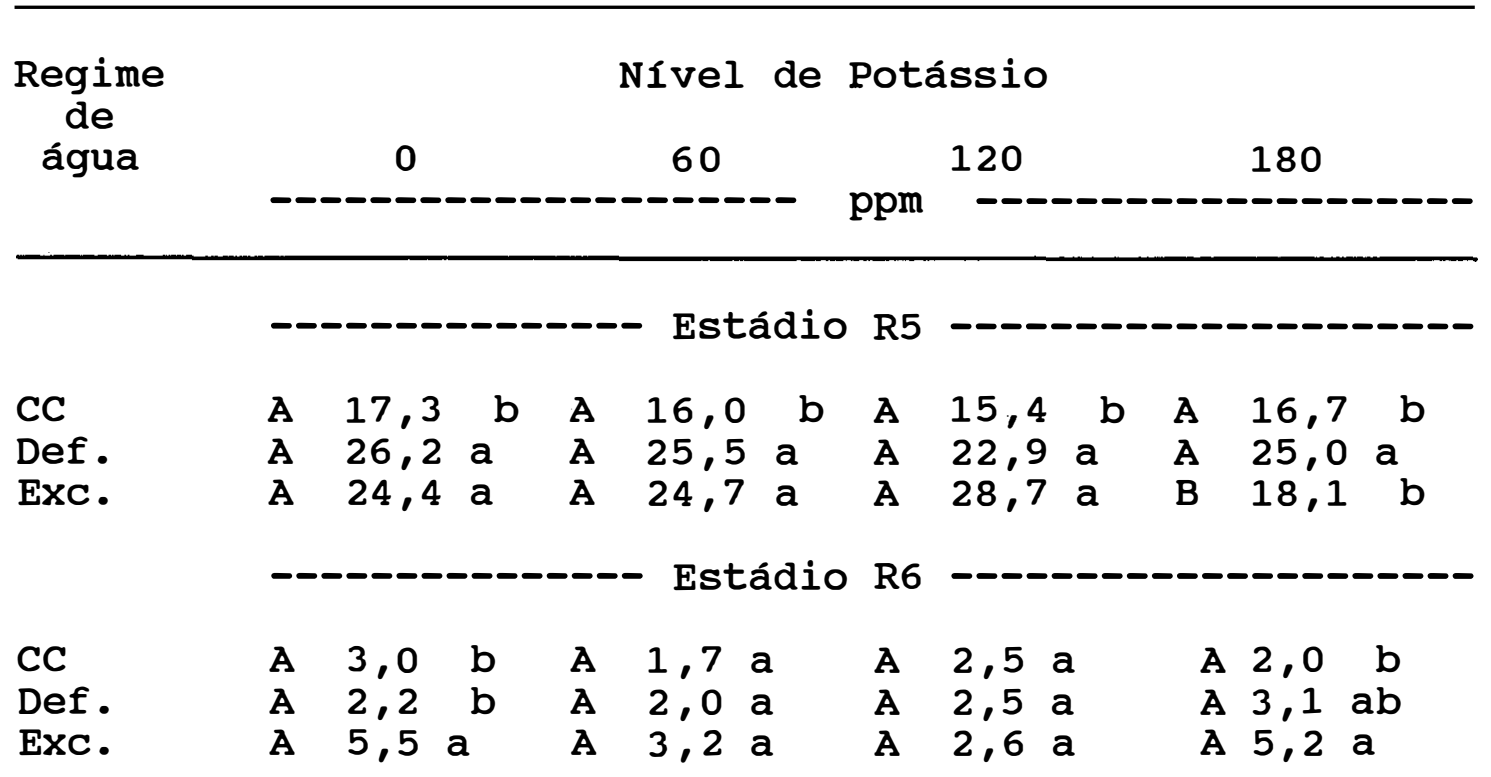

Médias antecedidas da mesma letra maiuscula na linha ou seguidas da mesma letra minuscula na coluna náo diferem significativamente entre si pelo teste de Duncan ao nivel de 5 de probabilidade.

Tabela 5. Duração em dias do estádio R7 (média de quatro repetições).

\begin{tabular}{|c|c|c|c|c|}
\hline $\begin{array}{l}\text { Regime } \\
\text { de }\end{array}$ & & Jíve & Eáss & \\
\hline água & 0 & 60 & 120 & 180 \\
\hline
\end{tabular}

Aplicação de água na época R5

$\begin{array}{llrrr}\text { CC } & 8,7 \frac{1}{1} & 8,0 & 8,0 & 8,1 \\ \text { Def. } & 6,5 & 6,2 & 7,0 & 6,7 \\ \text { ExC. } & 7,4 & 9,5 & 7,1 & 7,9\end{array}$

----- Aplicação de água na época R7

$\begin{array}{lllll}\text { CC } & 8,7 & 7,9 & 7,7 & 7,5 \\ \text { Def. } & 7,9 & 8,0 & 7,2 & 8,7 \\ \text { ExC. } & 9,1 & 8,0 & 8,2 & 8,7\end{array}$

I' Não houve diferenças significativas entre tratamentos. 
Tabela 6. Duração em dias do estádio R8 (média de quatro repetições) .

\begin{tabular}{|c|c|c|c|c|}
\hline \multirow{2}{*}{$\begin{array}{c}\text { Regime } \\
\text { de } \\
\text { água }\end{array}$} & \multicolumn{4}{|c|}{ Nível de potássio } \\
\hline & 0 & 60 & 120 & 180 \\
\hline
\end{tabular}

$\begin{array}{lllllllllllll} & & \text { Aplicação de água na época R5 } \\ \text { CC } & \text { A } & 17,4 & \text { a } & \text { B } 11,1 & \text { b } & \text { B } 10,9 & \text { b } & \text { AB } 12,9 & \text { a } \\ \text { Def. } & \text { A } & 18,8 & \text { a } & \text { A } & 17,4 & \text { a } & \text { A } & 16,7 & \text { a } & \text { A } & 16,3 & \text { a } \\ \text { Exc. } & \text { A } & 15,5 & \text { a } & \text { A } & 13,9 & \text { ab } & \text { A } & 16,8 & \text { a } & \text { A } & 15,2 & \text { a }\end{array}$

------ Aplicação de água na época $R 7$

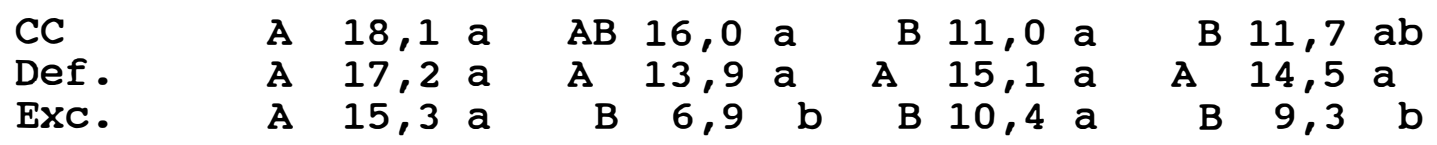

Medias antecedidas da mesma letra maiuscula na linha ou seguidas da mesma letra minuscula na coluna nå diferem significativamente entre si pelo teste de Duncan ao nivel de $5 \%$ de probabilidade.

Tabela 7. Duração do ciclo em dias desde a germinação até a maturação fisiológica (média de 4 repetições).

\begin{tabular}{|c|c|c|c|c|}
\hline Regime & & Jíve & Eáss: & \\
\hline água & 0 & 60 & 120 & 180 \\
\hline
\end{tabular}

(nplicação de água na época R5 ------

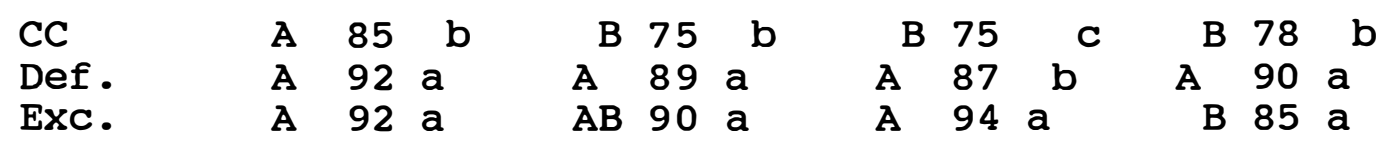

----- Aplicação de água na época R7

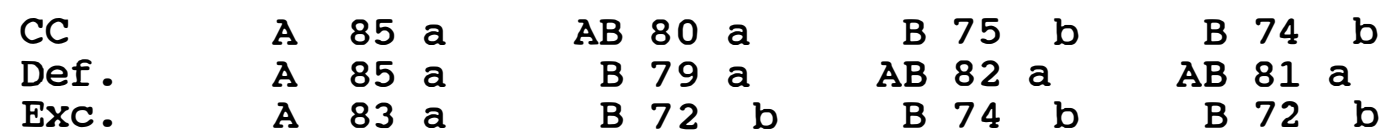

Medias antecedidas da mesma letra maiuscula na linha ou seguidas da mesma letra minuscula na coluna ná diferem significativamente entre $\mathrm{si}$ pelo teste de Duncan ao nivel de $5 \%$ de probabilidade. 
Considerando-se os tratamentos em capacidade de campo, a adubação potássica diminuiu a duração do estádio R8 e, em conseqüência, o ciclo total.

O estádio R5 foi prolongado entre sete e nove dias em decorrência da deficiência hídrica no início da préfloração, que também teve efeito sobre a duração do estádio de enchimento de vagens (R8), prolongando-o entre três e seis dias nas plantas adubadas com níveis de potássio, o que resultou em um atraso de uma a duas semanas na maturação fisiológica (figura 5).

DUBETZ \& MAHALLE (1969), ROBINS \& DOMINGO (1956) E BERGAMASCHI et al. (1988) também obtiveram desenvolvimento mais lento das vagens, quando aplicaram estresse na pré-floração.

Quando a deficiência hídrica foi induzida no início do estádio R7, a maturação fisiológica atrasou em uma semana (nas doses 120 e $180 \mathrm{ppm}$ de $\mathrm{K}$, tabela 7 ), sendo que 0 atraso esteve distribuido entre os estádios R7 (tabela 5) e R8 (tabela 6).

o ciclo total foi maior para as plantas com deficiência hídrica na época R5 em comparação com aquelas deficientes na época R7 nas doses zero, 60 e 180ppm de potássio (tabela 7).

A saturação hídrica na época R5 causou prolongamento do estádio R5 (nas doses 0,60 e 120ppm de K), do estádio R6 (0 e 180ppm de $k$ ) (tabela 4) e do estádio R8 
40.

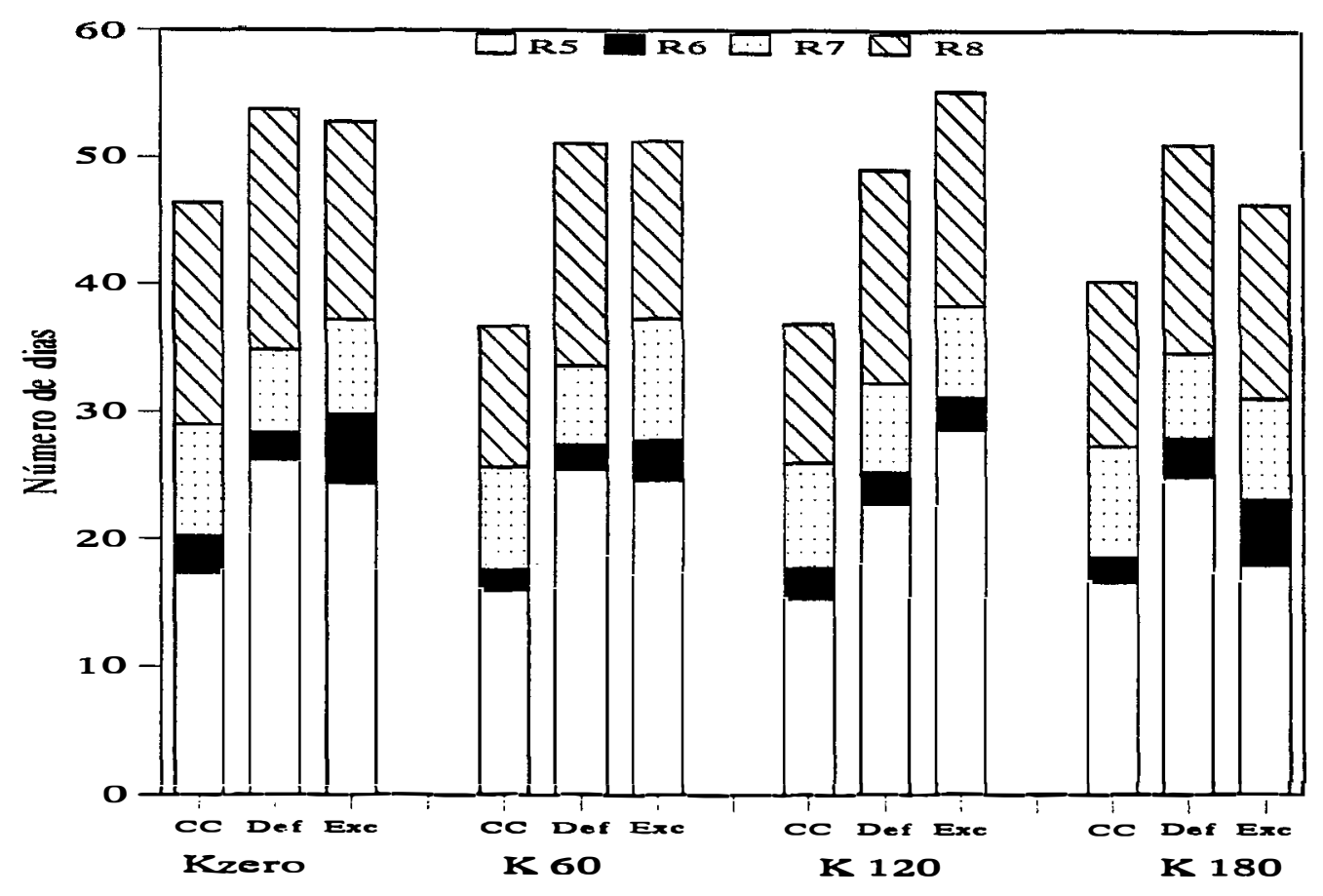

Figura 5. Duração em dias dos estádios R5, R6, R7 e R8 para as plantas tratadas com aplicação de água na época R5 (pré-floração).

(120ppm de $\mathrm{K}$, tabela 6), aumentando o ciclo entre sete a 19 dias em relação à capacidade de campo contínua (tabela 7 , figura 5).

Na dose 180ppm de potássio, nas plantas em solo saturado na época $R 5$, o número de dias na pré-floração não foi afetado (tabela 4), tornando o ciclo total mais curto em relação às doses zero, 60 e 120ppm de $K$ (tabela 7) . 
A saturação hídrica na época R7 diminuiu a duração do estádio R8 (dose 60ppm de $K$, tabela 6), diminuindo em oito dias o ciclo total (tabela 7), nesta mesma dose. Para as plantas em solo saturado na época R7, a adição de potássio reduziu o estádio $\mathrm{R} 8$ e o ciclo total.

Comparando-se as plantas sob excesso hidrico do solo nas duas épocas de aplicação dos regimes de água, observa-se que a saturação aplicada no estádio R5 prolongou - estádio R8 em uma semana (nas doses 60, 120 e 180ppm de K) (tabela 6) e o ciclo total (em todas as doses de potássio).

4.3. Lâmina de água aplicada

Não houve diferença significativa entre os tratamentos quanto às quantidades de água aplicadas nos estádios $V_{0}(15 \mathrm{~mm} /$ vaso), V1 (4mm/vaso), V2 (26mm/vaso) e R6 (15mm/vaso)

Os resultados desta variável nos estádios V3, V4 e R5 encontram-se na Tabela 8; nos estádios R7 e R8, nas Tabelas 9 e 10, respectivamente. A lâmina total consumida pelos tratamentos encontra-se na Tabela 11.

Nos tratamentos com solo em capacidade de campo continua, houve pequena demanda por água durante o período vegetativo, até o início do florescimento (R5), que foi o estádio que mais demandou água. 
Tabela 8. Lâmina de água aplicada nos estádios V3, V4 e R5 ( $\mathrm{mm}$ ) .

$\underset{\text { de }}{\text { Regime }}$

água

Nivel de potássio

$----$

60

120

180

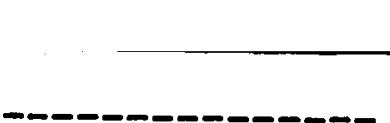

Estádio V3

$\mathrm{CC}^{1 /}$

B 58

A $\quad 64$

AB 61

A 63

Estádio V4

$\mathrm{CC}^{2 /}$

B 33

A $\quad 39$

A 37

A $\quad 39$

Estádio R5

$\mathrm{CC}^{2 \prime}$

B 91 a

Def.

B $83 a$

ExC.

A 71 a

A $144 \quad a$

A 140 a

AB 113 a

A 81 b

A $120 \mathrm{ab}$

A 155 a

ucdiag ante

MGdias antecedidas da mesma letra maluscula na linha ou seguidas da mesma letra minuscula na coluna $1 /$ madia de 12 repetiços.

21 madia de 12 repetiçós.

Houve efeito do potássio nas plantas cultivadas com solo em capacidade de campo. As plantas adubadas com potássio consumiram mais água nos estádios V3, V4, R5 (tabela 8) e R7 (tabela 9), resultando em maior lâmina total de água consumida (tabela 11). Estes resultados mostram o efeito da nutrição potássica sobre as plantas desde estádios iniciais, pois o teor de potássio no solo original do experimento encontra-se na classe de teor muito baixo proposta por RAIJ (1981) . A adição de potássio propiciou maior desenvolvimento do dossel das plantas, com maior área foliar e, em conseqüência, maior transpiração. 
Tabela 9. Lâmina de água aplicada no estádio R7 (mm), média de quatro repetições.

\begin{tabular}{|c|c|c|c|c|}
\hline \multirow{2}{*}{$\begin{array}{c}\text { Regime } \\
\text { de } \\
\text { água }\end{array}$} & \multicolumn{4}{|c|}{ Nivel de potássio } \\
\hline & 0 & 60 & 120 & 180 \\
\hline
\end{tabular}

Aplicação de água na época R5

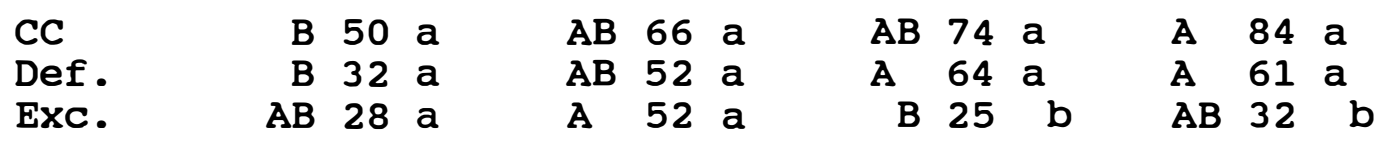

Aplicação de água na época R7 -------

$\begin{array}{lllllllllllll}\text { CC } & \text { B } & 42 & \mathrm{a} & \mathrm{A} & 69 & \mathrm{a} & \mathrm{AB} & 62 & \mathrm{ab} & \mathrm{A} & 70 & \mathrm{a} \\ \text { Def. } & \mathrm{A} & 29 & \mathrm{a} & \mathrm{A} & 31 & \mathrm{~b} & \mathrm{~A} & 39 & \mathrm{~b} & \mathrm{~A} & 34 & \mathrm{~b} \\ \text { ExC. } & \mathrm{A} & 54 & \mathrm{a} & \mathrm{A} & 72 & \mathrm{a} & \mathrm{A} & 68 & \mathrm{a} & \mathrm{A} & 78 & \mathrm{a}\end{array}$

Medias antecedidas da mesma letra maluscula na linha ou seguidas da mesma letra minuscula na coluna nso diferem significativamente entre $\mathrm{si}$ pelo teste de Duncan ao nivel de 58 de probabilidade.

Tabela 10. Lâmina de água aplicada no estádio R8 (mm), média de quatro repetições.

\begin{tabular}{|c|c|c|c|c|}
\hline Regime & & Jive & Eáss & \\
\hline água & 0 & 60 & 120 & 180 \\
\hline
\end{tabular}

Aplicação de água na época R5

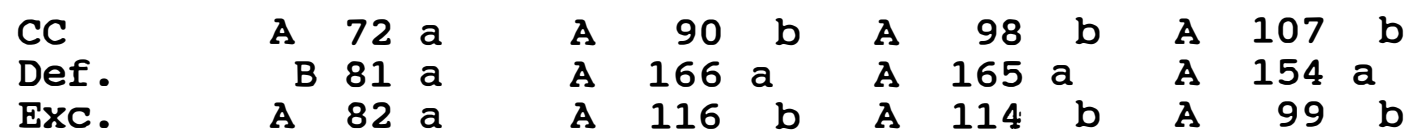

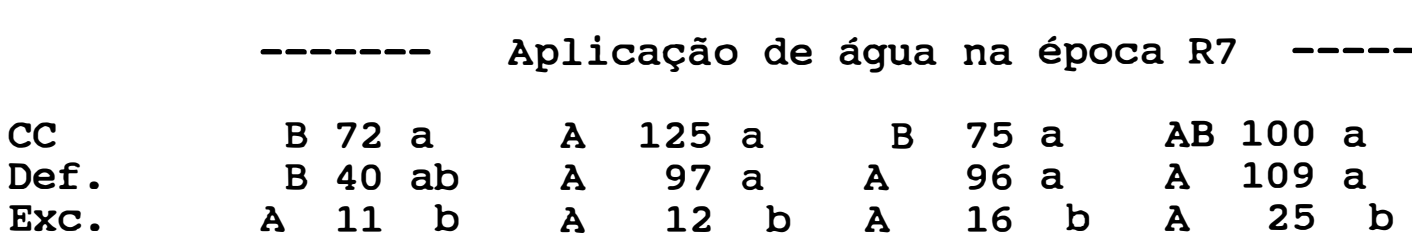


Tabela 11. Lâmina total de água (mm) aplicada durante o ciclo, desde a germinação até a maturação fisiológica (média de quatro repetições).

\begin{tabular}{|c|c|c|c|c|}
\hline \multirow{2}{*}{$\begin{array}{c}\text { Regime } \\
\text { de } \\
\text { água }\end{array}$} & \multicolumn{4}{|c|}{ Nivel de potássio } \\
\hline & 0 & 60 & 120 & 180 \\
\hline
\end{tabular}

----- Aplicação de água na época R5 -----

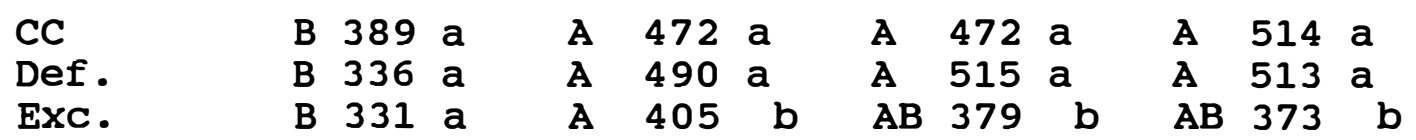

Aplicação de água na época $\mathrm{R} 7$

$\begin{array}{lllllllllllll}\text { CC } & \text { B } & 384 & \text { a } & \text { A } & 488 & \text { a } & \text { A } & 470 & \text { a } & \text { A } & 461 & \text { a } \\ \text { Def. } & \text { B } & 326 & \text { a } & \text { A } & 435 & \text { ab } & \text { A } & 427 & \text { ab } & \text { A } & 438 & \text { ab } \\ \text { ExC. } & \text { A } & 340 & \text { a } & \text { A } & 379 & \text { b } & \text { A } & 376 & \text { b } & \text { A } & 398 & \text { b }\end{array}$

MGdias antecedidas da messa letra maldscula na linha ou seguldas da mesma letra minuscula na coluna Medias antecedidas da messa letra maidscula na linha ou seguidas da mesma letra minuscula na col
ndo diferes significativamente entre si pelo teste de Duncan ao nivel de $5 \%$ de probabilidade.

As plantas em solo com deficiência hídrica na época R5 consumiram maior volume de água no estádio R8 em relação ao tratamento com solo em capacidade de campo nos níveis 60,120 e 180ppm de potássio adicionado ao solo (tabela 10).

As plantas em solo com deficiência hídrica na época R7 consumiram menos água nesse estádio (doses 60, 120 e 180ppm de potássio) em relação ao tratamento em capacidade de campo.

Comparando-se as épocas de indução da deficiência hídrica no solo, a pré-floração (época R5) causou maior consumo de água nos estádios R7 (nas doses 120 e 180ppm 
de $K$, tabela 9) e R8 (em todas as doses de $K$ testadas, tabela 10), e no ciclo total (dose 120ppm de $\mathrm{K}$, tabela 11). Houve portanto, maior sensibilidade das plantas à deficiência hídrica no início do estádio R7. Neste tratamento, diminuiu a utilização de água pelas plantas em estádios de elevado consumo como o R7 e R8 (CAIXETA, 1978), com efeitos mais evidentes nas plantas melhor nutridas, que têm maior demanda por água.

As plantas em solo com deficiência hídrica na época R5, quando adubadas, consumiram mais água nos estádios R5 (tabela 8), R7 (tabela 9), R8 (tabela 10) e total (tabela 11) .

A aplicação de doses de potássio ao solo teve efeito sobre o consumo de água das plantas cultivadas sob deficiência hídrica do solo na segunda época, nos estádios R8 (tabela 10) e no ciclo total (tabela 11).

Em relação ao tratamento com solo em capacidade de campo, a saturação hídrica do solo na pré-floração causou menor absorção de água pelas plantas nos estádios R5 $(60,120$ e 180ppm K, tabela 8) e R7 (tabela 9). LETEY et al. (1962) também relataram que as plantas com baixos suprimentos de oxigênio absorveram menos água.

A recuperação destas plantas foi retardada em aproximadamente 30 dias, visto que voltaram a absorver água normalmente somente no estádio R8 (tabela 10). A absorção total no ciclo manteve-se menor para as doses 60,120 e 
180ppm de potássio. Segundo HOLDER \& BROWN (1980), o tempo que as raizes permanecem com deficiência de oxigênio é um fator que determina a capacidade de recuperação das plantas. Neste trabalho, deve-se considerar que após os cinco dias de tratamento, provavelmente ainda houve um período de deficiência de oxigênio menos severa, pois o solo dos vasos demandou um tempo maior para atingir teores correspondentes à capacidade de campo.

Segundo GLINSKY \& STEPNIEWSKI (1986), a tolerância de uma planta ao encharcamento depende, além das propriedades do solo e sua temperatura, também do estádio de desenvolvimento. As plantas no solo com saturação hídrica na época R5 mostraram enraizamento superficial, em todos os níveis de $\mathrm{K}$, como mecanismo de adaptação ao estresse, o qual não ocorreu no tratamento de excesso no estádio R7.

A saturação hídrica do solo na época R7 causou a diminuição da absorção de água pelas plantas no estádio R8 (em todas as doses de potássio), e no ciclo total (doses 60, 120 e 180ppm de K), em relação à capacidade de campo.

Em todos os tratamentos de saturação hídrica do solo, observou-se murchamento das plantas. 0 murchamento pode ser induzido pela má aeração no solo, devido a menor absorção de água decorrente da diminuição da permeabilidade das raízes (KRAMER, 1983), com aumento da resistência radicular ao fluxo de água. Embora não se tenha medido diretamente a absorção de água pelas plantas, observa-se na 
Tabela 12 que a lâmina de água aplicada durante os cinco dias de tratamento de saturação hídrica do solo na época R5 foi menor que aquela aplicada aos vasos em capacidade de campo. $\mathrm{Na}$ época $\mathrm{R7}$ observa-se também a mesma tendência, porém nesse caso, os tratamentos foram aplicados no período de $12 / 9$ a $21 / 9$ e as condições externas de temperatura e umidade relativa não foram iguais para todos os níveis dos tratamentos, embora não tenham sido alcançados extremos muito diferentes nesse período (figuras 2 e 3 ).

Tabela 12. Lâmina de água aplicada (mm) durante os cinco dias de duração dos regimes de água (média de quatro repetições) .

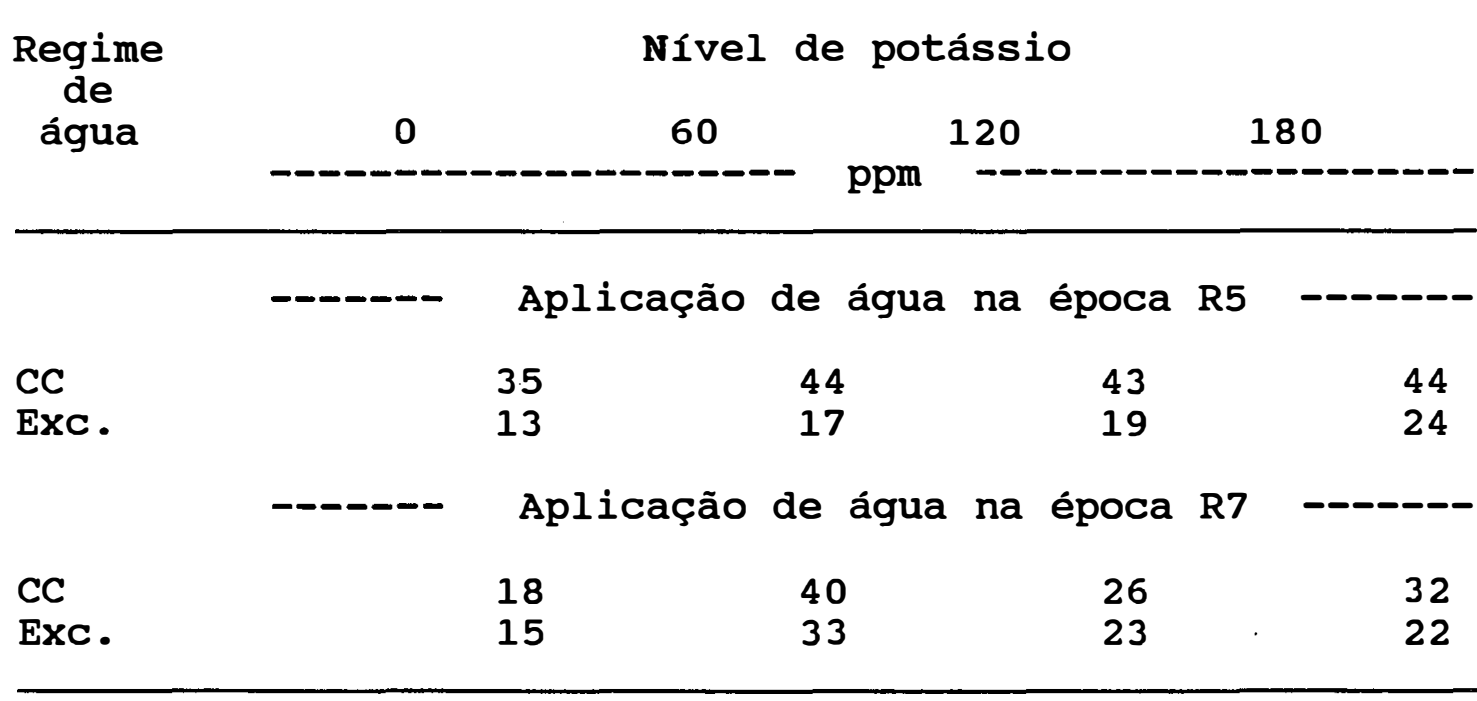

o efeito das doses de potássio aplicadas ao solo sobre a lâmina total de água, nos três níveis de água aplicados ao solo, é visto na Figura 6 , onde verifica-se que para a capacidade de campo e a deficiência hídrica do solo, 
a maior lâmina de água consumida correspondeu às doses de 137 e $131 \mathrm{ppm}$ de potássio, respectivamente, e para o excesso hídrico no solo, a faixa estudada mostrou consumo crescente de água até $180 \mathrm{ppm}$ de potássio aplicado ao solo.

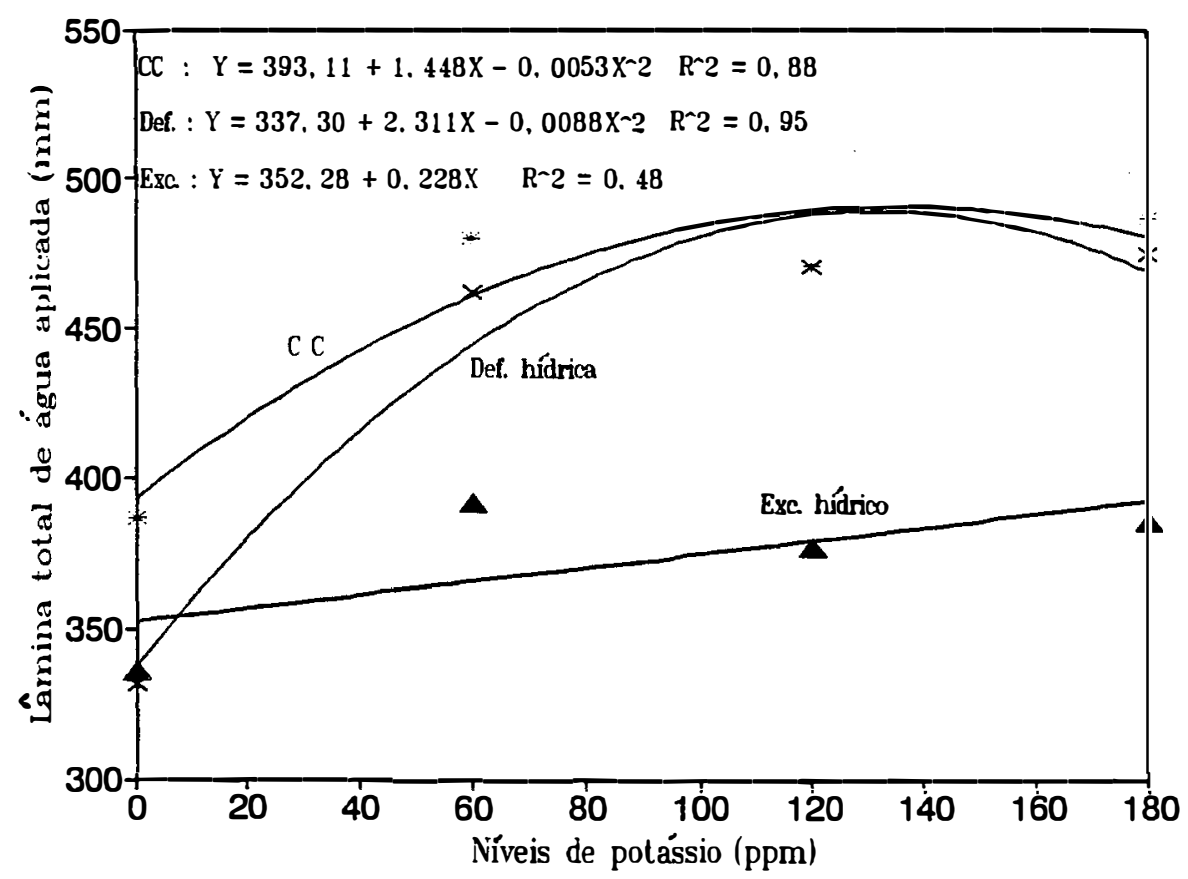

Figura 6. Curvas de regressão e coeficientes de determinação $\left(R^{\wedge} 2\right)$ da lâmina total de água aplicada para doses de potássio aplicadas ao solo em três regimes de água (médias de quatro repetições).

4.4. Altura das plantas

o crescimento das plantas em altura foi afetado pelos tratamentos, conforme pode-se observar nos diversos estádios (tabelas 13, 14 e 15) e na variação de altura em 
cada tratamento (figuras 7 e 8 ).

Tabela 13. Variação da altura de plantas(cm) nos estádios V3, V4, R5 e R6.

\begin{tabular}{|c|c|c|c|c|}
\hline $\begin{array}{c}\text { Regime } \\
\text { de }\end{array}$ & & Niv & Eáss: & \\
\hline água & 0 & 60 & 120 & 180 \\
\hline
\end{tabular}

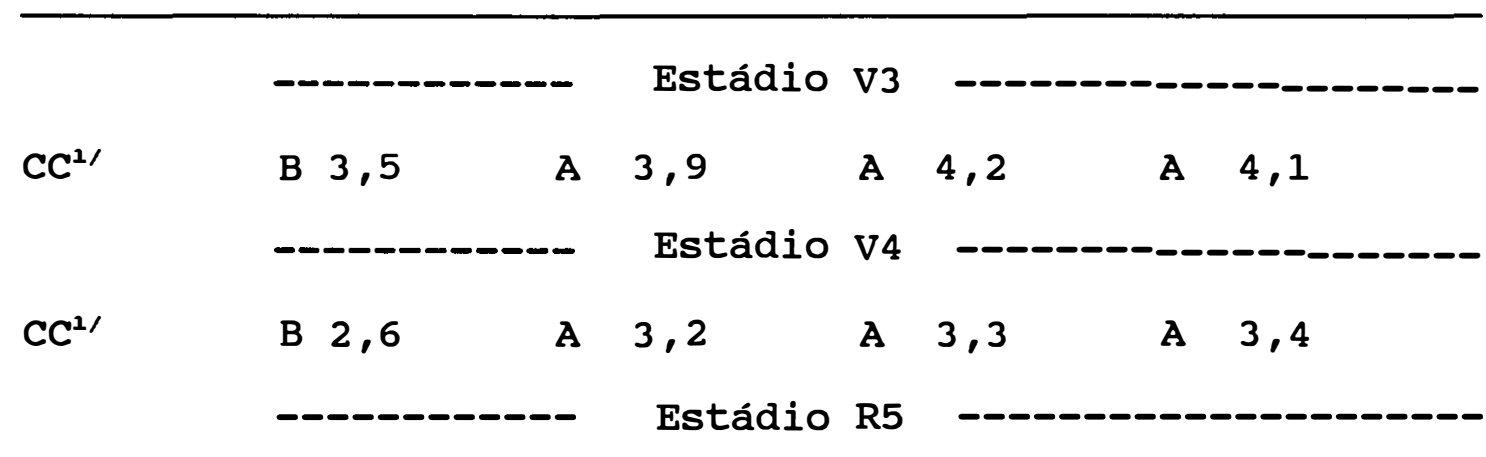

$\begin{array}{llrrrrrrrrrrrr}\text { CC }^{21} & \text { B } & 16,8 & \text { a } & \text { B } & 27,2 & \text { a } & \text { B } & 27,0 & \text { a } & \text { A } & 43,0 & \text { a } \\ \text { Def. } & \text { A } & 11,8 & \text { ab } & \text { A } & 14,5 & \text { b } & \text { A } & 18,1 & \text { a } & \text { A } & 21,1 & \text { b } \\ \text { ExC. } & \text { A } & 3,8 & \text { b } & \text { A } & 6,1 & \text { b } & \text { A } & 6,2 & \text { b } & \text { A } & 6,4 & \text { C }\end{array}$

Estádio R6

\begin{tabular}{|c|c|c|c|c|c|c|c|c|c|c|}
\hline $\begin{array}{l}\text { CC } \\
\text { Def. } \\
\text { Exc. }\end{array}$ & ${ }_{A}^{A}$ & $\begin{array}{ll}1,9 & a \\
0,8 & a \\
1,4, & a\end{array}$ & ${ }_{A}^{A}$ & $\begin{array}{l}2,0 \\
1,2 \\
0,6\end{array}$ & $\begin{array}{l}a \\
a \\
a\end{array}$ & ${ }_{A}^{A}$ & $\begin{array}{l}4,4 \\
2,2 \\
0,4\end{array}$ & $\begin{array}{l}a \\
a b\end{array}$ & $A$ & $\begin{array}{ll}2,5 & b \\
6,4 & \mathrm{a} \\
1,5 & \mathrm{~b}\end{array}$ \\
\hline
\end{tabular}

Medias antecedidas da mesma letra maiuscula na linha ou seguidas da mesma letra minuscula na coluna náo diferem significativamente entre $\mathrm{si}$ pelo teste de Duncan ao nivel de $5 \%$ de probabilidade.

$1 /$ media de 12 repetiçóes.

/media de 4 repetiços.

Para as plantas no tratamento com solo em capacidade de campo, houve efeito da adubação nos estádios V3, V4 (tabela 13) e R7 (tabela 14). No estádio R5 houve efeito da dose 180ppm de potássio sobre o crescimento em altura (tabela 13). 
50.

Tabela 14. Variação da altura de plantas $(\mathrm{cm})$ no estádio $\mathrm{R7}$ (média de quatro repetições).

\begin{tabular}{|c|c|c|c|c|}
\hline Regime & & IIve & Eáss & \\
\hline água & 0 & 60 & 120 & 180 \\
\hline
\end{tabular}

Aplicação de água na época R5

$\begin{array}{lcccccccccccc}\text { CC } & \mathrm{B} & 2,6 & \mathrm{a} & \mathrm{AB} & 6,1 & \mathrm{a} & \mathrm{A} & 8,6 & \mathrm{a} & \mathrm{A} & 8,7 & \mathrm{a} \\ \text { Def. } & \mathrm{C} & 0,7 & \mathrm{a} & \mathrm{BC} & 2,2 & \mathrm{a} & \mathrm{AB} & 5,8 & \mathrm{a} & \mathrm{A} & 7,2 & \mathrm{a} \\ \text { ExC. } & \mathrm{AB} & 2,9 & \mathrm{a} & \mathrm{A} & 5,6 & \mathrm{a} & \mathrm{AB} & 1,7 & \mathrm{~b} & \mathrm{~B} & 1,0 & \mathrm{~b}\end{array}$

------ Aplicação de água na época R7

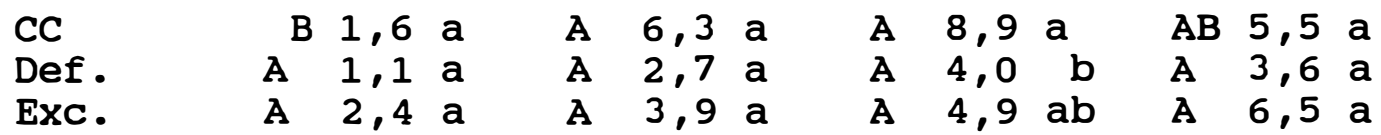

MGdias antecedidas da mesma letra maiuscula na linha ou seguidas da mesma letra mindscula na coluna nfo diferem significativamente entre 81 pelo teste de Duncan ao nivel de 5 de probabilidade.

Tabela 15. Variação da altura de plantas ( $\mathrm{cm}$ ) no estádio R8 (média de quatro repetições).

\begin{tabular}{|c|c|c|c|c|}
\hline $\begin{array}{l}\text { Regime } \\
\text { de }\end{array}$ & & Iive & Eáss & \\
\hline água & 0 & 60 & 120 & 180 \\
\hline
\end{tabular}

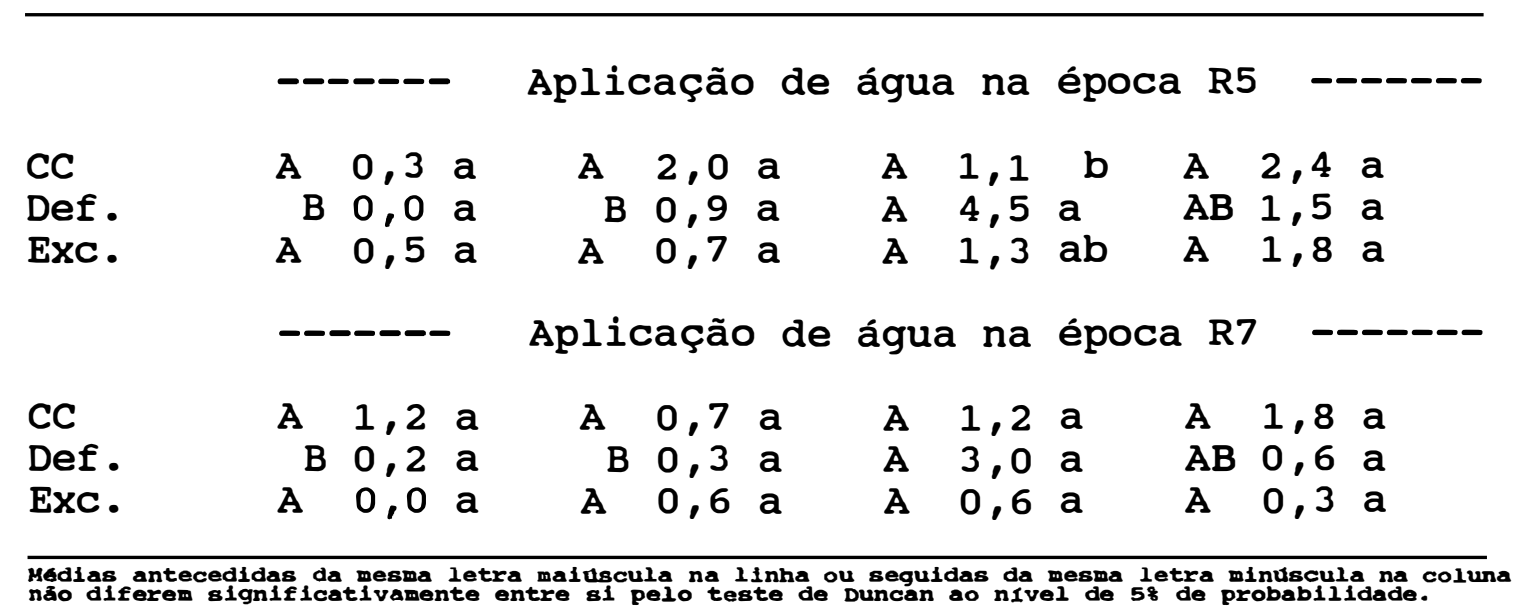


51.

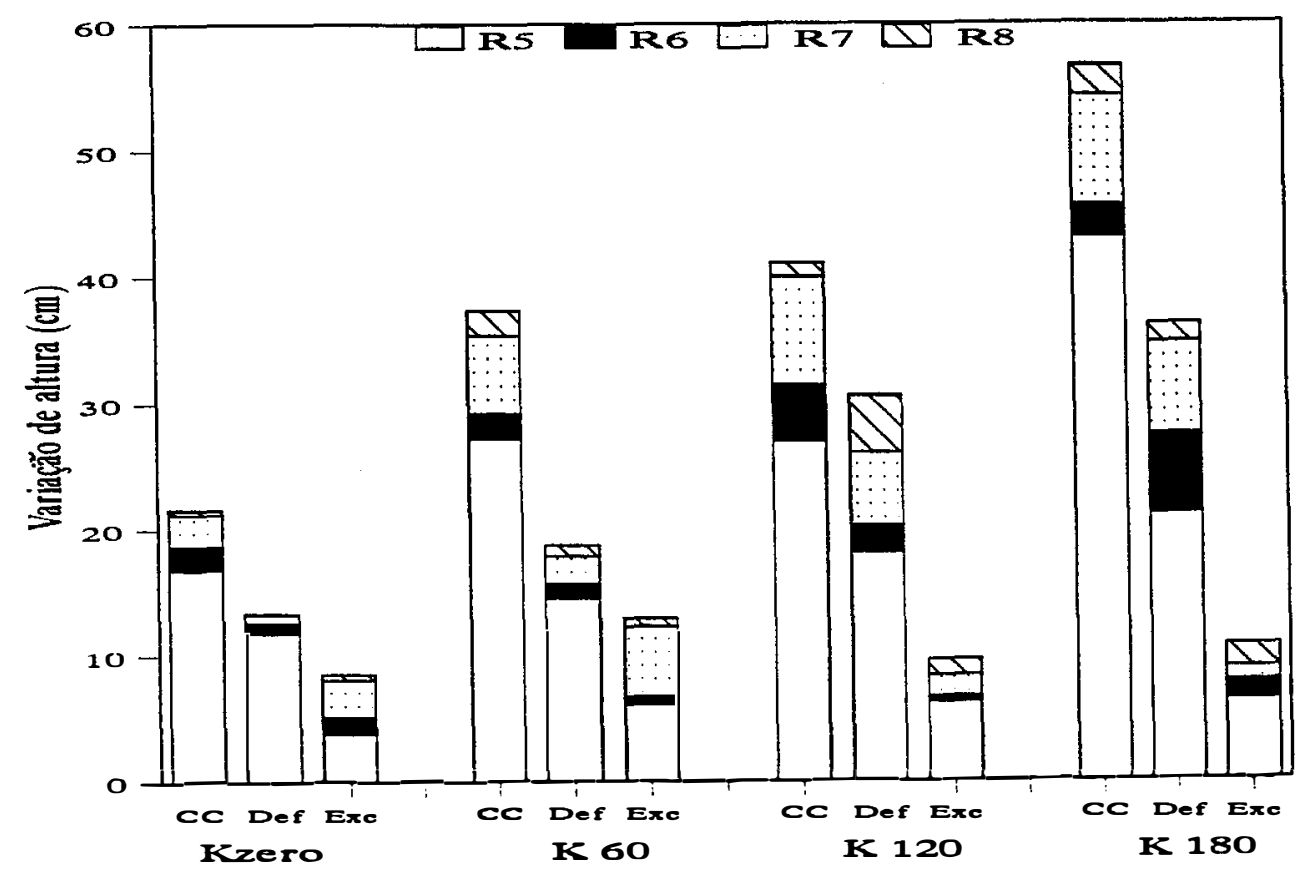

Figura 7. Variação da altura das plantas com aplicação de água na época R5 (pré-floração).

Segundo OzBUN et al. (1965), a deficiência de potássio retarda o crescimento ativo das folhas em poucos dias, pois esse nutriente tem importância significativa durante o desenvolvimento das células foliares.

A deficiência hídrica do solo na época R5 reduziu o crescimento em altura das plantas no periodo de pré-floração (tabela 13), afetando o crescimento final da haste principal (figura 7). A diminuição no crescimento por alongamento é uma resposta da planta ao decréscimo da turgescência celulàr (HSIAO, 1973; CLELAND, 1971). Além deste efeito direto da deficiência hídrica no solo, este resultado, 
52.

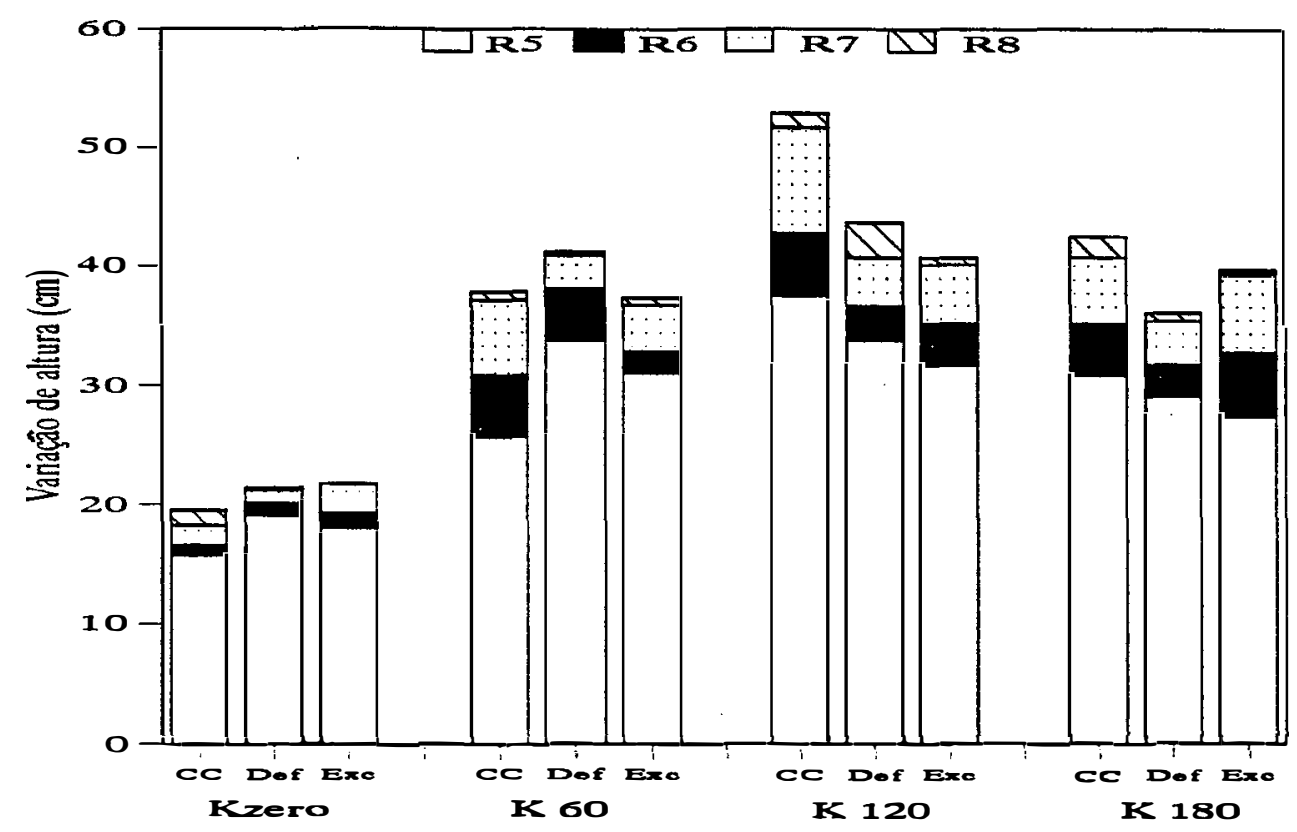

Figura 8. Variação da altura das plantas com aplicação de água na época R7 (início de formação de vagens).

em parte, pode ser devido a um distúrbio na nutrição mineral (BEGG \& TURNER, 1976), uma vez que as doses maiores de potássio ocasionaram maior crescimento. A importância do $\mathrm{K}^{+}$ para retenção de água e para manutenção do turgor celular foi demonstrada por MENGEL \& ARNEKE (1982). Quanto à deficiência hídrica do solo na época R7, esta praticamente não afetou o desenvolvimento das plantas em altura (figura 8).

No estádio $R 6$, a dose 180ppm de potássio aumentou o crescimento das plantas em solo deficiente em água na primeira época (tabela 13); no estádio R7, todas as doses 
de adubação incrementaram a variação em altura desse tratamento (tabela 14)

Nas plantas em solo saturado, observou-se epinastia nos pecíolos, ocorrendo mudança no ângulo entre eles e o caule. Na parte aérea, observou-se sintomas visuais de clorose, senescência e abscisão de folhas, diminuindo assim a massa da parte aérea das plantas.

Houve efeito significativo das doses de potássio sobre a altura total das plantas nos três níveis de água estudados, conforme se observa na Figura 9.

A aplicação de doses crescentes de potássio resultou em efeito linear crescente e acentuado da altura das plantas em solo em capacidade de campo, e menos intenso nas plantas em solo com excesso hídrico, enquanto que a altura máxima para as plantas em solo com deficiência hídrica foi estimada para a dose de $145 \mathrm{ppm}$ de potássio aplicado ao solo. Em cultivares indeterminados, o hábito de desenvolvimento é contínuo, com acréscimo no número de nós por um longo tempo (VILHORDO et al., 1988). Aliando-se a esta característica o cultivo em casa de vegetação, com períodos de sombreamento, esperava-se obter plantas com alturas superiores às medidas, como oteve BULISANI (1994) com este cultivar, 1,60m. Os resultados obtidos, no entanto, mostram um grande efeito de condições ambientais desfavoráveis sobre as plantas, limitando seu desenvolvimento em altura e ramificações, com redução provavel no número de nós produzidos, que são 
54 .

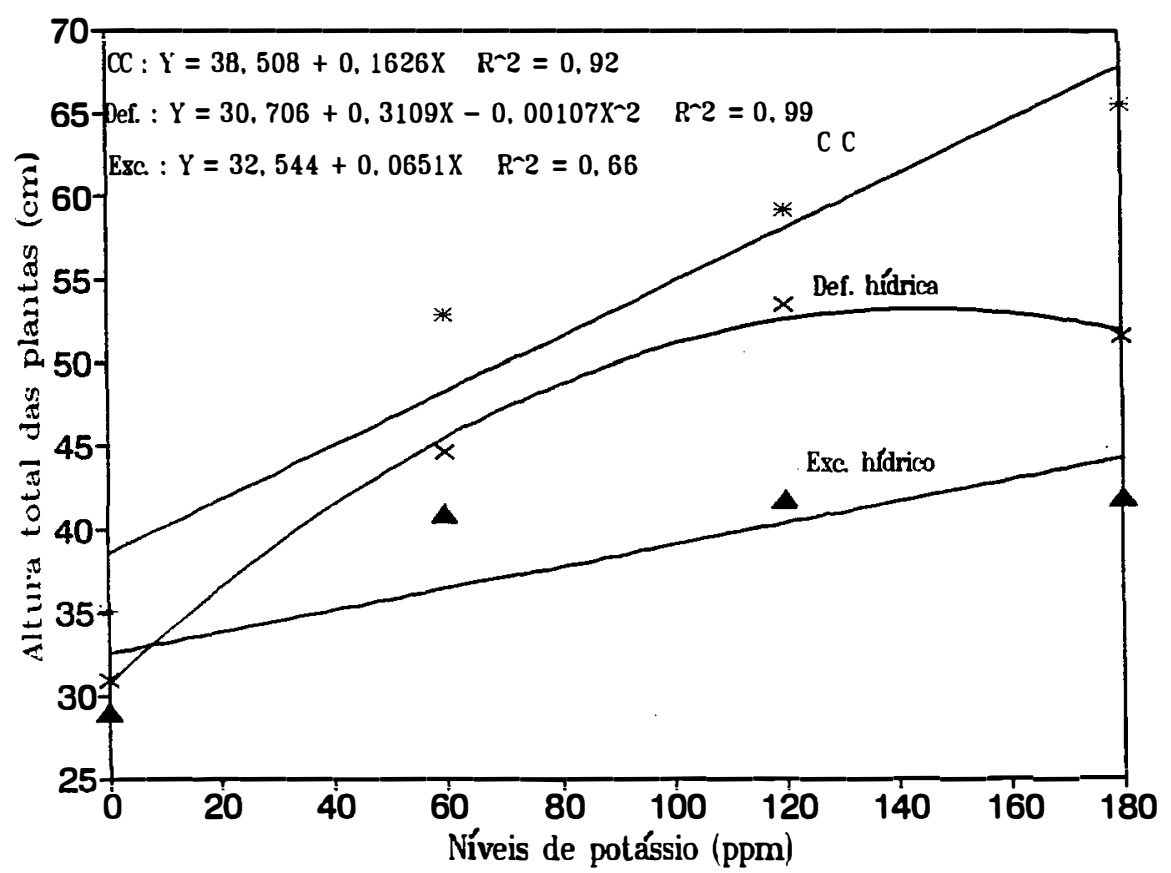

Figura 9. Curvas de regressão e coeficientes de determinação ( $R^{\wedge} 2$ ) da altura total das plantas para as doses de potássio aplicadas ao solo, em três regimes de água (médias de quatro repetições ).

relacionados diretamente com a produção de folhas e flores.

\subsection{Matéria seca da parte aérea}

A análise de variância da matéria seca produzida pela parte aérea das plantas, revelou interações significativas entre os efeitos dos tratamentos, como mostram os resultados da Tabela 16 e Figura 10. 
Tabela 16. Matéria seca produzida pela parte aérea ( $\mathrm{g} / \mathrm{planta,} \mathrm{média} \mathrm{de} \mathrm{quatro} \mathrm{repetições).}$

\begin{tabular}{|c|c|c|c|c|}
\hline \multirow{2}{*}{$\begin{array}{c}\text { Regime } \\
\text { de } \\
\text { água }\end{array}$} & \multicolumn{4}{|c|}{ Nivel de potássio } \\
\hline & 0 & 60 & 120 & 180 \\
\hline
\end{tabular}

Aplicação de água na época R5

$\begin{array}{lllllllllllll}\text { CC } & \text { B } & 4,04 & \text { a } & \text { AB } & 5,20 & \text { a } & \text { AB } & 5,13 & \text { a } & \text { A } & 6,30 & \text { a } \\ \text { Def. } & \text { B } & 4,00 & \text { a } & \text { AB } & 4,64 & \text { a } & \text { A } & 5,43 & \text { a } & \text { AB } & 5,10 & \text { b } \\ \text { ExC. } & \text { A } & 2,33 & \text { b } & \text { A } & 3,36 & \text { b } & \text { A } & 3,23 & \text { b } & \text { A } & 3,27 & \text { C }\end{array}$

----- Aplicação de água na época R7

$\begin{array}{lllllllllllll}\text { CC } & \text { B } & 3,61 & \text { a } & \text { A } & 5,04 & \text { a } & \text { A } & 5,20 & \text { ab } & \text { A } & 5,81 & \text { a } \\ \text { Def. } & \text { C } 2,83 & \text { a } & \text { B } & 4,18 & \text { a } & \text { A } & 5,55 & \text { a } & \text { AB } & 5,28 & \text { a } \\ \text { ExC. } & \text { B } & 2,90 & \text { a } & \text { A } & 4,60 & \text { a } & \text { A } & 4,19 & \text { b } & \text { AB } & 3,80 & \text { b }\end{array}$
nóo diferem significativamente entre si pelo teste de Duncan ao nivel de 58 de probabilidade.

Comparando-se os tratamentos com deficiência hídrica no solo e os tratamentos com solo em capacidade de campo, houve redução da matéria seca da parte aérea apenas no tratamento aplicado na época R5, no nível 180ppm de potássio. Este comportamento deveu-se à plasticidade fenotípica demonstrada pelo cultivar, a qual permitiu-lhe produzir novas folhas, recuperando as que foram perdidas com a senescência induzida pelos tratamentos.

A deficiência hídrica do solo na época R7, comparada com a deficiência na época R5, diminuiu a matéria seca no nível oppm de potássio. 


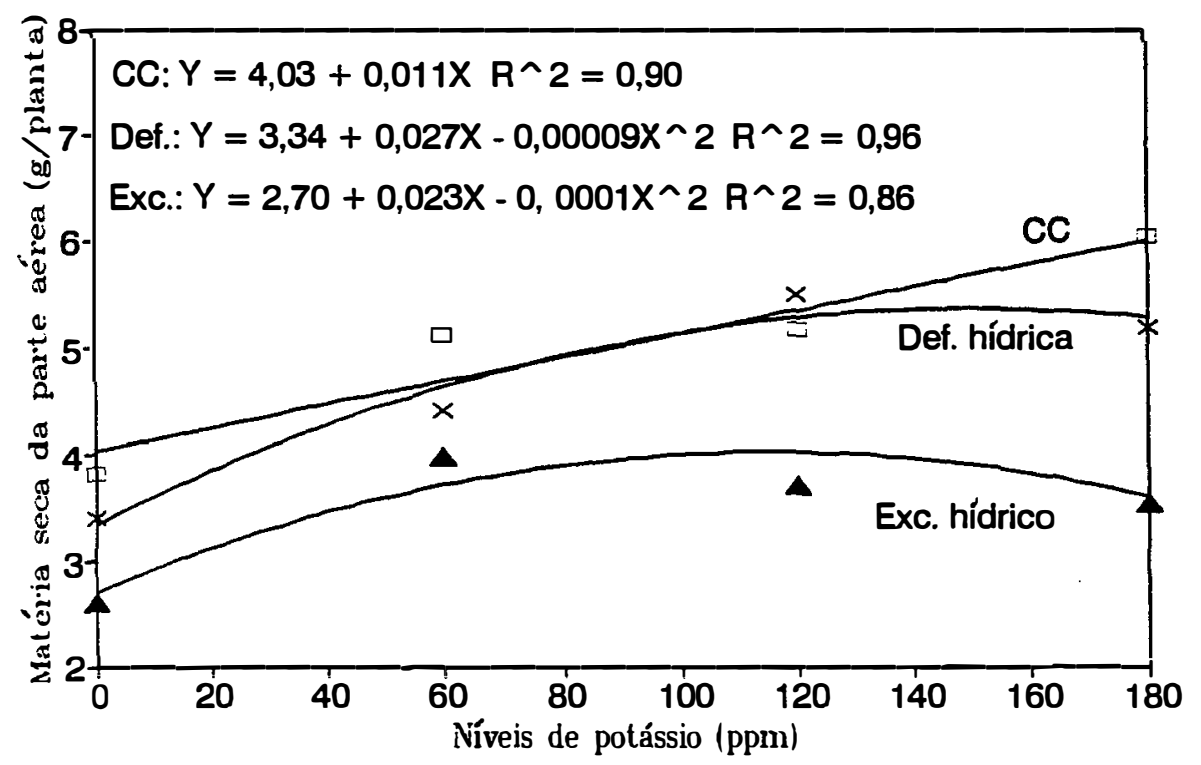

$$
\square \mathrm{CC} \times \text { Def. } \triangle \text { Exc. }
$$

Figura 10. Curvas de regressão e coeficientes de determinação ( $R^{\wedge} 2$ ) da matéria seca produzida pela parte aérea para as doses de potássio aplicadas ao solo, em três regimes de água (médias de quatro repetições).

Na época R5, o excesso de água aplicado ao solo reduziu a produção de matéria seca das plantas, em função da recuperação lenta das mesmas. A época $R 7$ mostrou-se menos sensível à saturação do solo, pois causou redução somente na maior dose de potássio (tabela 16).

Para as plantas conduzidas no regime hídrico de solo em capacidade de campo, a matéria seca produzida pela parte aérea teve resposta linear crescente às doses de potássio aplicadas ao solo (figura 10). Para os regimes de deficiência ou excesso hídricos no solo, houve resposta 
57.

quadrática, com produção máxima nas doses de 150 e 110ppm de $\mathrm{K}$, respectivamente.

Segundo MENGEL \& KIRKBY (1987), é freqüente que experimentos com fertilizantes mostrem curvas de produção com um ponto de inversão, dado que a produção resulta de processos físicos, químicos, bioquímicos e fisiológicos que são afetados por outros fatores, além do nutriente estudado. No caso do potássio, os autores citam a possibilidade de que, em excesso, este nutriente diminua a absorção de outros cátions, particularmente do $\mathrm{Mg}$, com conseqüente resposta quadrática da produção à sua aplicação.

\subsection{Matéria seca de raízes}

Houve interações significativas entre os níveis de água aplicados ao solo, as épocas de aplicação e os níveis de potássio estudados, para a variável matéria seca de raízes (tabela 17).

Avaliando-se as médias dos tratamentos no solo em capacidade de campo nas duas épocas, não se observou efeito dos níveis de potássio. A deficiência e a saturação hídricas do solo na época R5 causaram menor produção final de raízes em relação ao solo mantido em capacidade de campo, para as plantas não adubadas.

Como as plantas são de crescimento indeterminado, o crescimento de raízes provavelmente não 
diminui intensamente por ocasião do florescimento (estádios R5 e R6). Dessa forma, a redução observada para o nível oppm de $\mathrm{K}$ aplicado ao solo deve estar refletindo o efeito da interação da deficiência hídrica com a deficiência do nutriente $\mathrm{K}^{+}$na planta, o qual tem importante efeito na translocação de produtos fotossintetados (MENGEL, 1982). Para as plantas cultivadas em solo com deficiência hídrica na época R5, poderia ser esperado um aumento na matéria seca produzida de raízes, com as plantas buscando obter maior superfície de absorção de água, uma vez que o fornecimento de fotoassimilados da parte aérea para as raízes é mais intenso até o florescimento (PORTES, 1988).

No entanto, esse estímulo da deficiência hídrica no solo parece não ter ocorrido, seja pela curta duração ou baixa intensidade do estresse a que as plantas foram submetidas, ou porque, segundo FANCELLI (1992) tal efeito só ocorre quando a deficiência se dá no início do desenvolvimento da cultura. A aplicação de potássio aumentou a produção de raízes no tratamento de deficiência hídrica no solo (figura 11), com produção máxima estimada para a dose de $124 \mathrm{ppm}$ de potássio aplicado ao solo.

\subsection{Análise foliar}

Os resultados obtidos na análise química das 
Tabela 17. Matéria seca de raízes ( $\mathrm{g} / \mathrm{planta,} \mathrm{média} \mathrm{de}$ quatro repetiçōes).

\begin{tabular}{|c|c|c|c|c|}
\hline $\begin{array}{c}\text { Regime } \\
\text { de } \\
\text { água }\end{array}$ & 0 & $\begin{array}{l}\text { Jivel } \\
60\end{array}$ & $\begin{array}{l}\text { Cáss } \\
120\end{array}$ & 180 \\
\hline
\end{tabular}

Aplicação de água na época R5

CC

$\begin{array}{llllllllllllllll}A & 2,64 & \mathrm{a} & \mathrm{A} & 2,67 & \mathrm{a} & \mathrm{A} & 2,66 & \mathrm{a} & \mathrm{A} & 2,60 & \mathrm{a}\end{array}$

Def.

B 1,36 b A 2,86 a

A 2,64 a

A 2,54 a

Exc.

A 1,22 b A 1,99 a

A 1,59 a

A 1,95 a

----- Aplicação de água na época R7

CC

Def.

B 1,65 a

B 1,28 a

ExC.

A 1,70 a
A 3,17 a

A 3,02 a

A 2,62 a
AB 2,66 a

A 2,99 a

A 1,79 a
AB 2,61 ab

A 3,12 a

A 1,84 b MGdias antecedidas da mesma letra maidscula na linha ou seguidas da mesma letra minuscula na coluna
nto diferem signif 1 cativamente entre 81 pelo teste de Duncan ao nivel de 5 de probabilidade.

folhas para os teores de N, P, K, Ca, Mg e S encontram-se nas Tabelas 18, 19, 20, 21, 22 e 23, respectivamente.

A aplicação de potássio ao solo, independente de dose, diminuiu o $\mathrm{N}$ das folhas no início do estádio $\mathrm{R7}$ e cinco dias após o início desse estádio nos tratamentos com deficiência e saturação hídricas do solo; para o tratamento com solo em capacidade de campo, houve decréscimo constante do teor de $\mathrm{N}$ com o aumento das doses de potássio aplicadas ao solo. Esse efeito pode ser devido à competição na absorção aniônica de cloreto, nitrato e fosfato e ao mecanismo duplo de absorção de cloreto nas plantas (EPSTEIN, 1966). Aparentemente, esse efeito desapareceu nos tratamentos sob deficiência e excesso hídricos do solo, embora se observe uma 
60 .

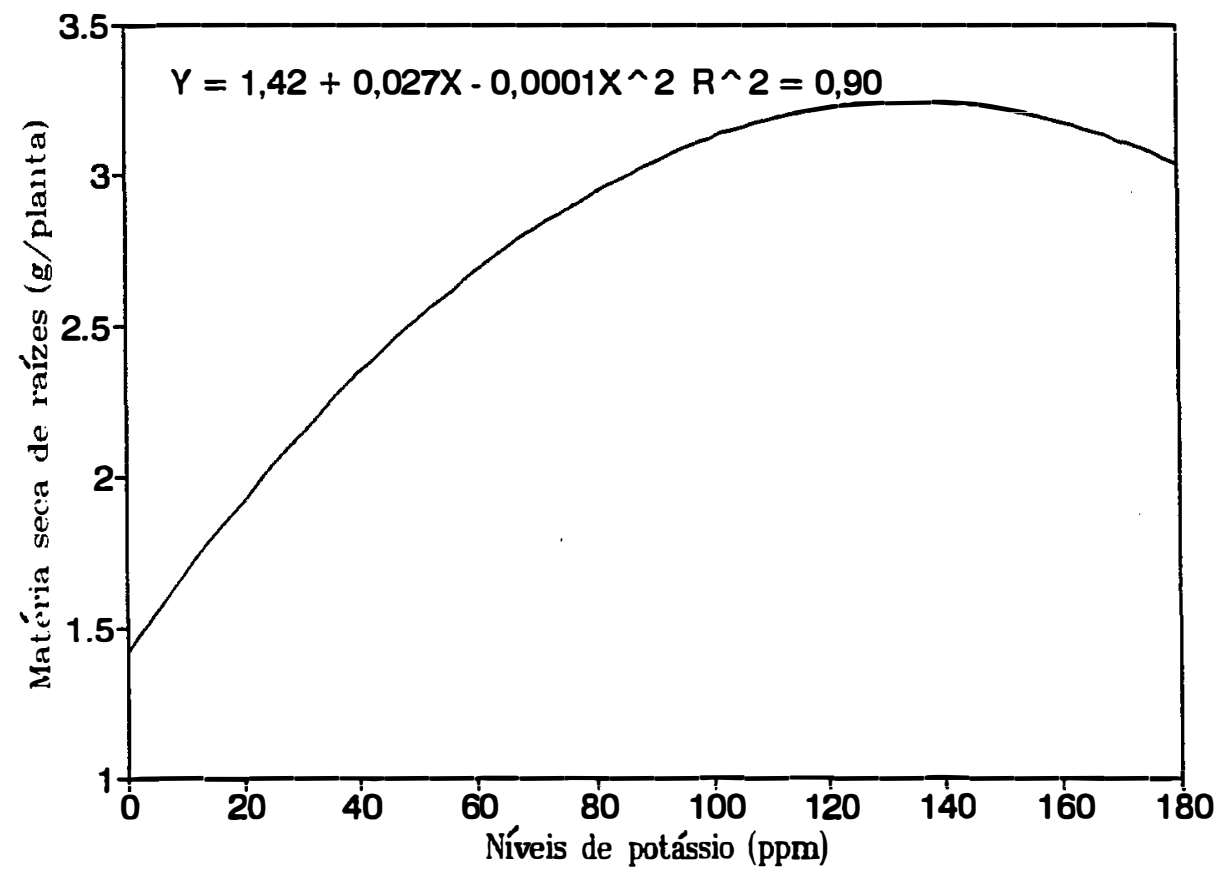

Figura 11. Curva de regressão e coeficiente de determinação $\left(R^{\wedge} 2\right.$ ) da matéria seca produzida pelas raizes para doses de potássio aplicadas ao solo no regime de deficiência hídrica (médias de quatro repetições).

ligeira queda entre os niveis zero e 60ppm de $K$.

Em plantas com melhor irrigação, o uso do $\mathrm{N}$ no crescimento pode diminuir o seu teor em relação às plantas cultivadas em baixos teores de umidade (ABDEL RAHMAN et al., 1971), pelo efeito de diluição. Esta tendência foi observada nas plantas do tratamento com deficiência hidrica do solo na época R7 e na maior dose de potássio aplicada (tabela 18). Nas demais doses, a deficiência de água no solo esteve associada a menores teores de $\mathrm{N}$ na folha, nas duas épocas. Este resultado pode estar relacionado com a queda na absorção 
Tabela 18. Teor foliar de nitrogênio (\%), média de quatro repetições.

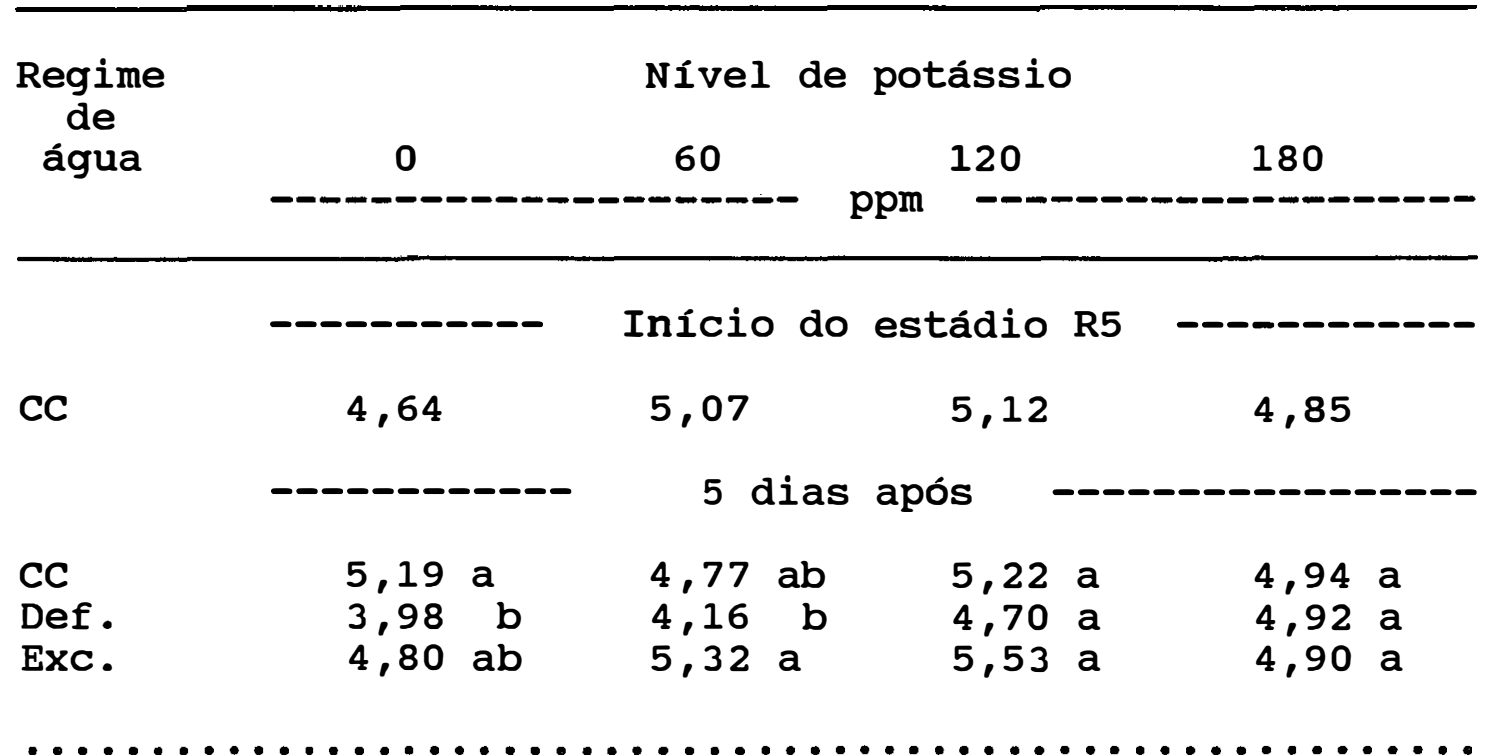

Início do estádio R7

CC

A 6,56

B 4,91

B 5,09

B 4,75

5 dias após

CC

Def.

Exc.

\begin{abstract}
A 5,96 a
\end{abstract}
A 5,76 a

A 5,52 a

$\begin{array}{rllllll}\text { AB } & 5,34 & \text { a } & \text { BC } & 4,74 & \text { a } \\ \text { AB } & 4,91 & \text { a } & \text { B } & 4,69 & \text { a } \\ \text { B } & 3,93 & \text { b } & \text { B } & 4,30 & \text { a }\end{array}$

$C 4,30 \mathrm{ab}$

AB 4,94 a

B 3,76 b

Medias antecedidas da mesma letra maiuscula na linha ou seguidas da mesma letra minuscula na coluna Medias antecedidas da mesma letra maiuscula na linha ou seguidas da mesma letra minuscula na col
năo diferem significativamente entre si pelo teste de Duncan ao nivel de 5 de probabilidade.

do nutriente do solo, em função da diminuição da transpiração das plantas, que pode afetar o fluxo de massa da solução do solo até as raízes.

Em relação aos teores foliares de $\mathrm{N}$ nas plantas no início do estádio R7, nos tratamentos de saturação do solo houve redução dos mesmos (nos níveis 0,60 e 180ppm de potássio). As plantas cultivadas sob deficiência hídrica na época R5 apresentaram menores teores de $\mathrm{N}$ em relação ao 
Tabela 19. Teor foliar de fósforo (\%), média de quatro repetições.

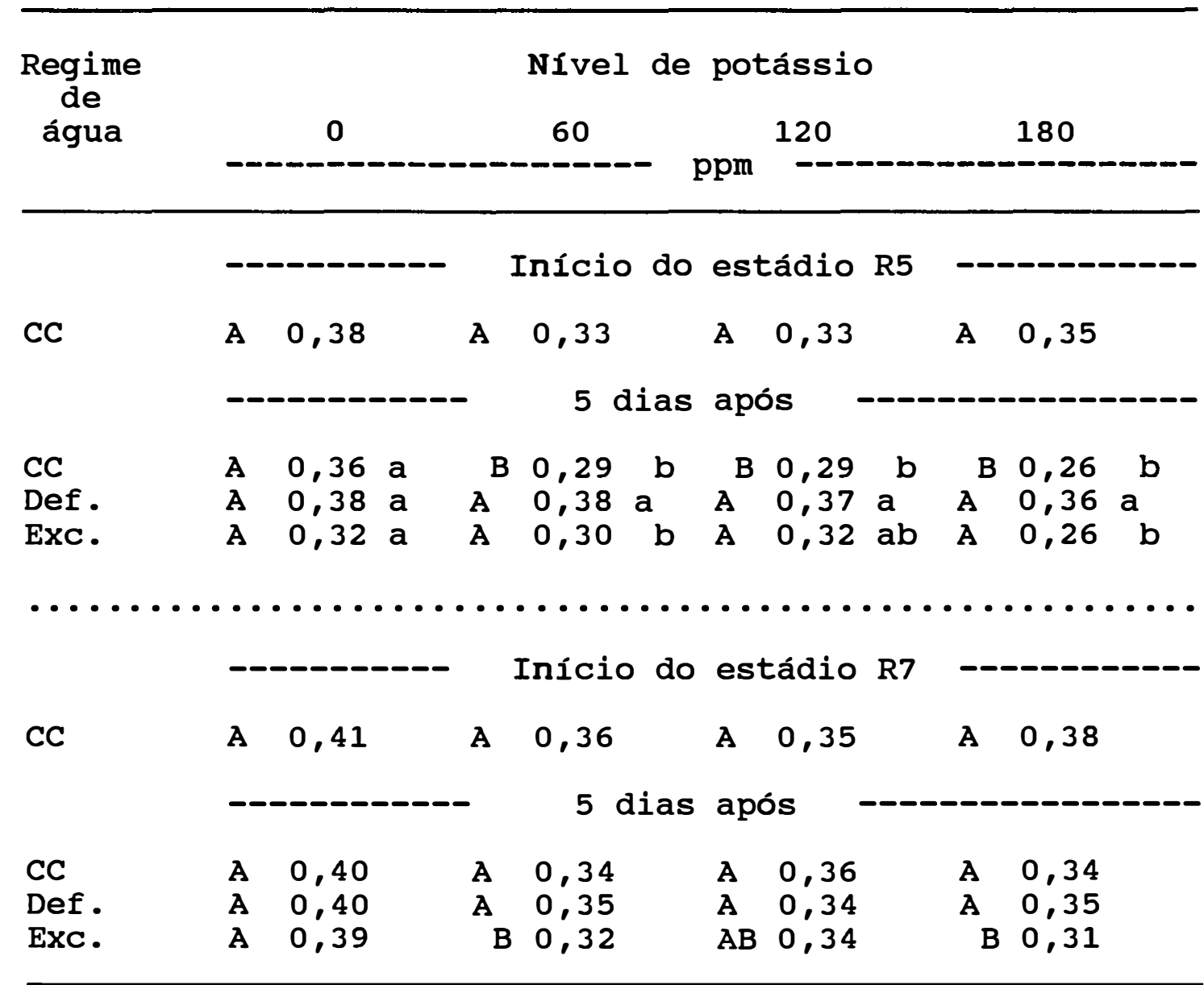

Medias antecedidas da mesma letra maluscula na linha ou seguidas da mesma letra minuscula na coluna
ná diferem significativamente entre si pelo teste de Duncan ao nivel de $5 z_{\text {de }}$ probabilidade.

cultivo no solo em capacidade de campo na dose oppm de potássio aplicado. As plantas cultivadas em solo saturado na época $\mathrm{R7}$ apresentaram menores teores de $\mathrm{N}$ em relação às cultivadas sob capacidade de campo (nivel 60ppm de potássio). No estádio R5, a aplicação de potássio diminuiu - teor de $\mathrm{P}$ nas folhas das plantas cultivadas em solo sob capacidade de campo (tabela 19). No estádio R7, este mesmo efeito foi verificado para as plantas em solo saturado. As 
Tabela 20. Teor foliar de potássio (\%), média de quatro repetições.

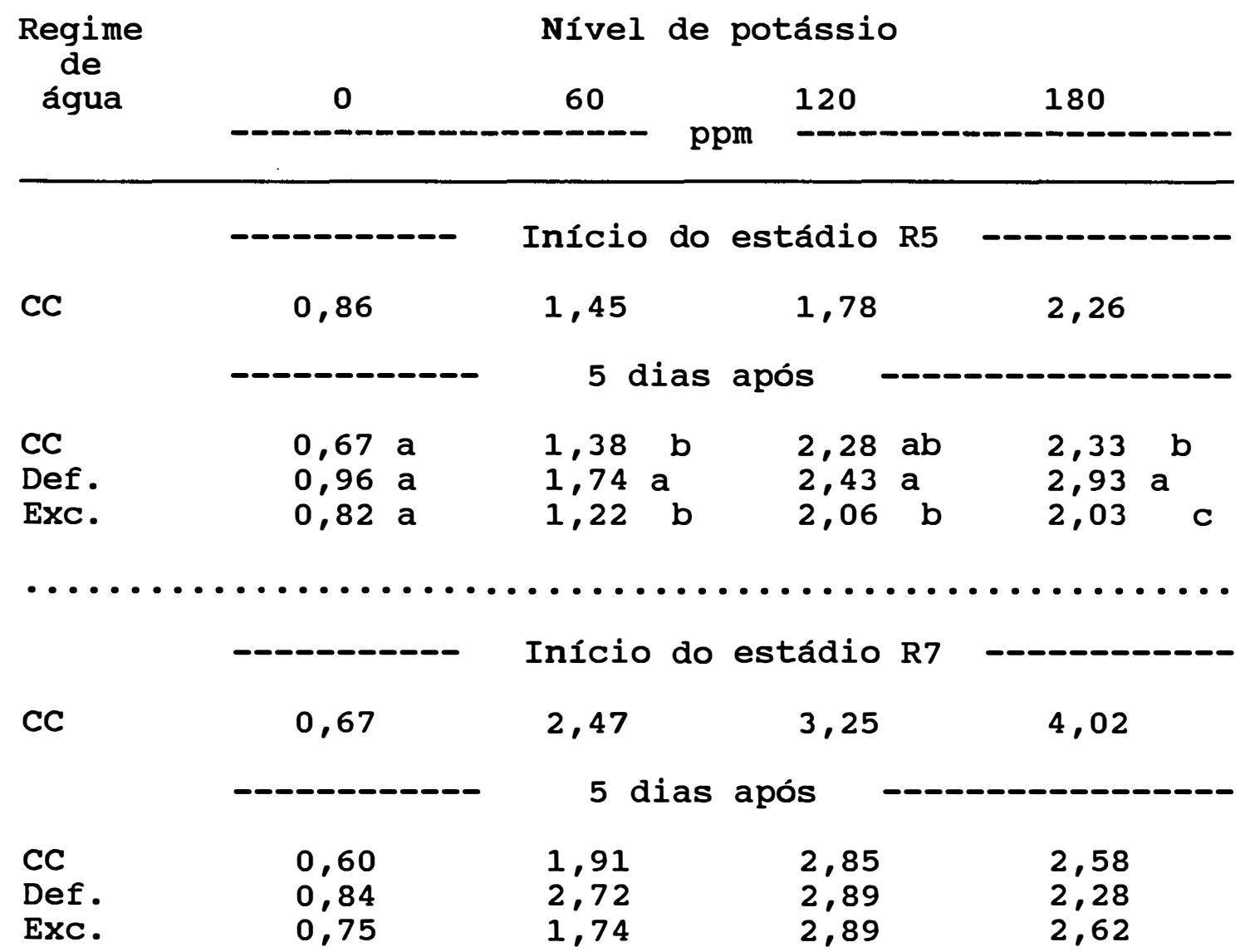

Medias seguidas da mesma letra minuscula na coluna náo diferem significativamente entre si pelo teste Medias seguldas da mesma letra minuscula na
de Duncan ao nivel de 5 de probabilidade.

plantas sob deficiência hídrica do solo na época R5 apresentaram maiores teores foliares de P (nas doses 60, 120 e 180ppm de potássio) do que as plantas em solo sob capacidade de campo.

Em relação aos teores foliares iniciais no estádio R5 (tabela 20), houve aumento significativo de $\mathrm{K}$ para os tratamentos em capacidade de campo (na dose 120ppm de potássio) e com solo sob deficiência hídrica (nas doses 120 
Tabela 21. Teor foliar de cálcio (\%), média de quatro repetições.

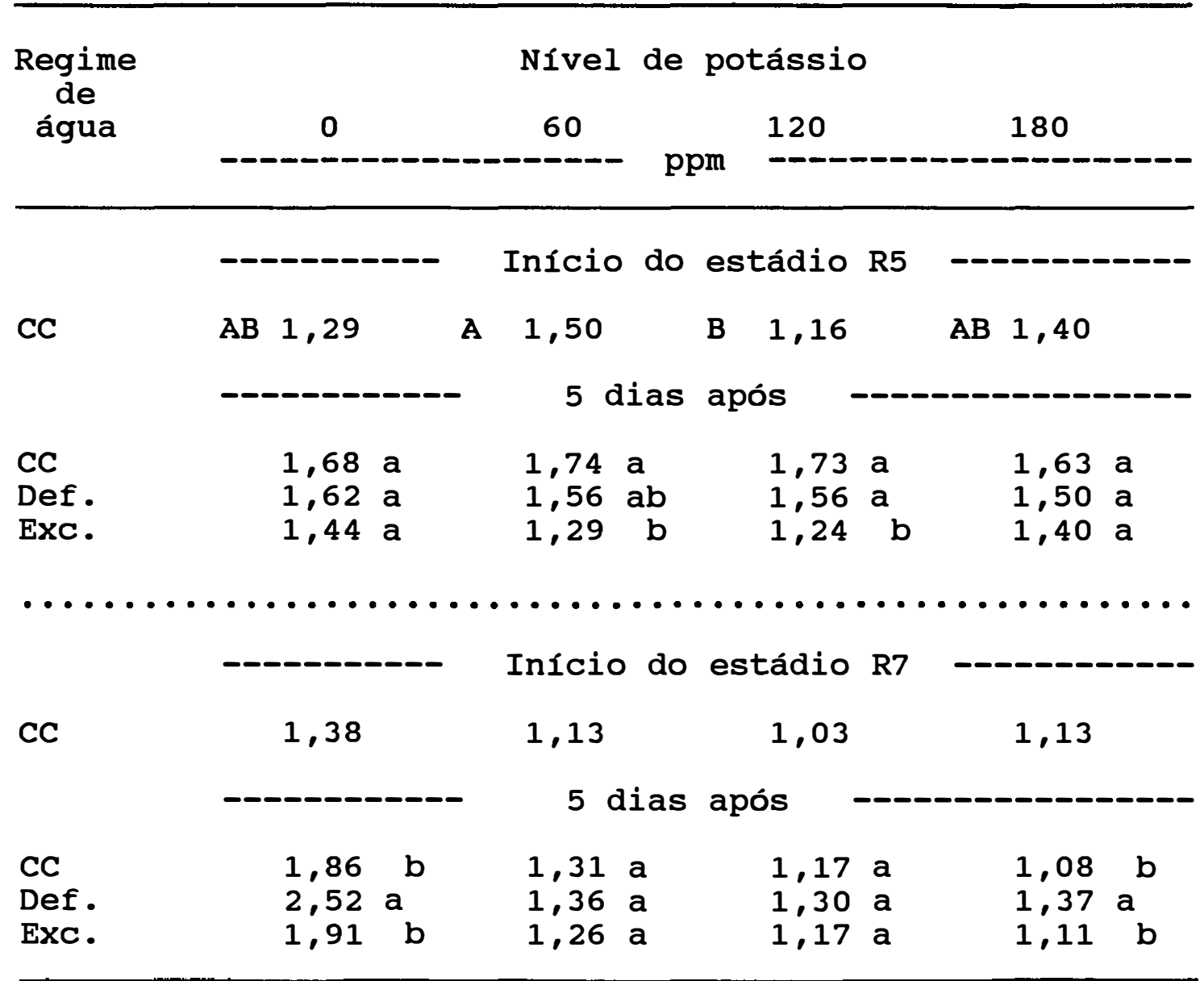

Medias antecedidas da mesma letra maluscula na linha ou seguldas da mesma letra minuscula na coluna

e 180ppm de potássio). A absorção de um nutriente numa taxa mais rápida do que o aumento da massa seca pode levar a esse aumento do teor percentual, como ocorreu no tratamento com deficiência hídrica no solo. Nesse caso, a deficiência de água estaria inibindo mais intensamente o crescimento da planta do que a absorção do potássio.

Comparando-se os teores das plantas cultivadas em solo sob deficiência hídrica na época $\mathrm{R} 5$ com as plantas 
Tabela 22. Teor foliar de magnésio (\%), média de quatro repetições.

\begin{tabular}{|c|c|c|c|c|}
\hline Regime & & líve & táss & \\
\hline água & 0 & 60 & 120 & 180 \\
\hline
\end{tabular}

Início do estádio R5

CC

0,45

0,38

0,32

0,35

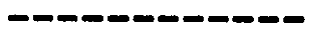

5 dias após

$\begin{array}{llllll}\text { CC } & 0,62 \mathrm{a} & 0,43 \mathrm{a} & 0,36 \mathrm{a} & 0,32 \mathrm{a} \\ \text { Def. } & 0,54 \mathrm{ab} & 0,42 \mathrm{a} & 0,37 \mathrm{a} & 0,40 \mathrm{a} \\ \text { Exc. } & 0,51 \mathrm{~b} & 0,36 \mathrm{a} & 0,31 \mathrm{a} & 0,33 \mathrm{a}\end{array}$

CC 0,52

CC

Def.

Exc.

Início do estádio R7
0,42
0,38
0,35

5 dias após
$0,46 a$
$0,36 \mathrm{a}$
0,38 a
$0,34 a$
0,51 a
0,34 a
0,36 a
0,43 a
0,34 a

Medias seguldas da mesma letra minuscula na coluna nāo diferem significativamente entre si pelo teste de Duncan ao nivel de 5 s de probabilidade.

cultivadas em solo sob capacidade de campo, ao final dos tratamentos (cinco dias após o início do estádio, tabela 20), houve maior teor de $K$ nas folhas quando 0 potássio foi adicionado ao solo. As plantas em solo saturado de água adubadas com $180 \mathrm{ppm}$ de potássio mostraram menor teor foliar de $K$.

Em outras espécies de plantas sob deficiência de oxigênio tem-se verificado diminuição no teor de $K$ nas 
Tabela 23. Teor foliar de enxofre (\%), média de quatro repetições.

\begin{tabular}{|c|c|c|c|c|}
\hline \multirow{2}{*}{$\begin{array}{c}\text { Regime } \\
\text { de } \\
\text { agua }\end{array}$} & \multicolumn{4}{|c|}{ Nível de potássio } \\
\hline & 0 & OU & 120 & 100 \\
\hline
\end{tabular}

Início do estádio R5

CC

A $0,22 \quad A B \quad 0,20$

B 0,18

$\mathrm{AB} 0,20$

5 dias após

CC

Def.

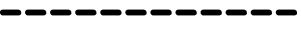

B 0,16 b A 0,20 a

A 0,21 a

$\begin{array}{llllll}A & 0,18 & \mathrm{ab} & \mathrm{A} & 0,19 & \mathrm{a} \\ \mathrm{A} & 0,20 & \mathrm{a} & \mathrm{A} & 0,19 & \mathrm{a}\end{array}$

A 0,21 a

$\mathrm{AB} 0,18 \mathrm{a}$

Exc.

A 0,20 a

0,20

A 0,20 a

A 0,19 a

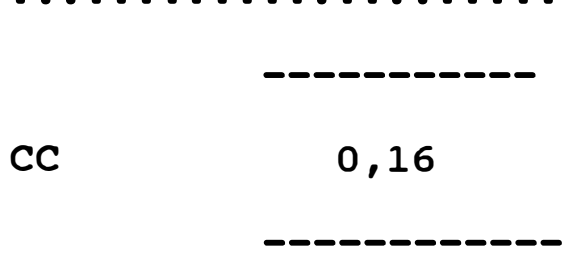

Início do estádio R7

CC

Def.

0,14

0,14

0,14

0,16

5 dias após

Exc.

0,14

0,14

0,16

0,14

0,13

0,13

0,14

0,14

0,14

0,15

0,16 Medias antecedidas da mesma letra maiuscula na linha e seguidas da mesma letra minuscula na coluna
nao diferem significativamente entre $\mathbf{s i}$ pelo teste de Duncan ao nivel de 58 de probabilidade.

partes aéreas (SOJKA \& STOLZY, 1980). O tempo que as plantas permaneceram em solo inundado pode ter sido insuficiente para permitir que a concentração foliar de $\mathrm{K}$ fosse afetada nas doses de 0,60 e 120ppm de potássio adicionado ao solo.

Os teores de $K$ nas folhas foram significativamente afetados pelo aumento das doses de potássio aplicadas ao solo, em todos os tratamentos, nas épocas R5 e R7 (figuras 12 e 13, tabela 24), dado o aumento 

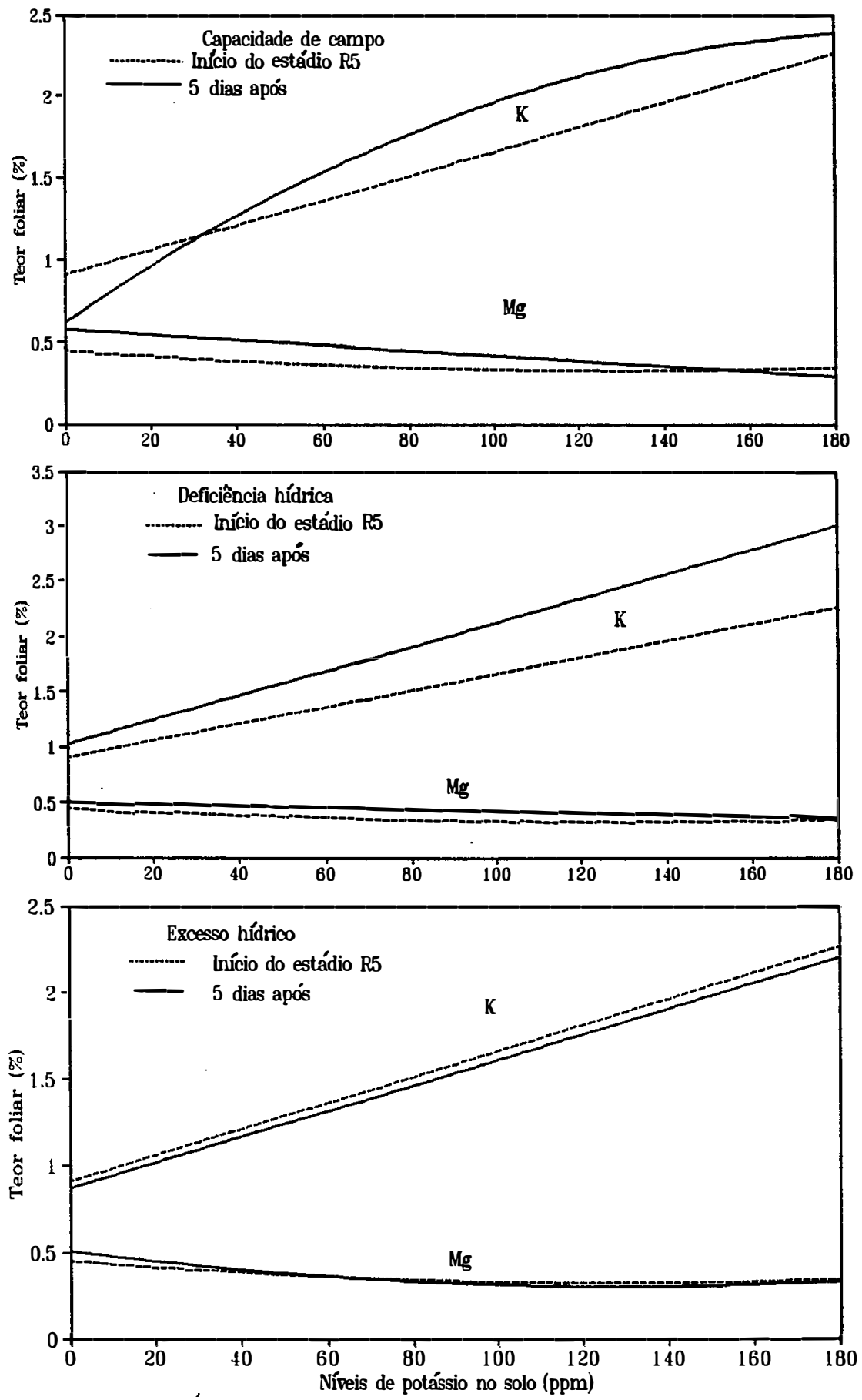

Figura 12. Curvas de regressão do teor foliar de $\mathrm{K}$ e Mg para doses de potássio aplicadas no solo, no início do estádio R5 e cinco dias após a aplicação de três níveis de água no solo (médias de quatro repetições). 
68.
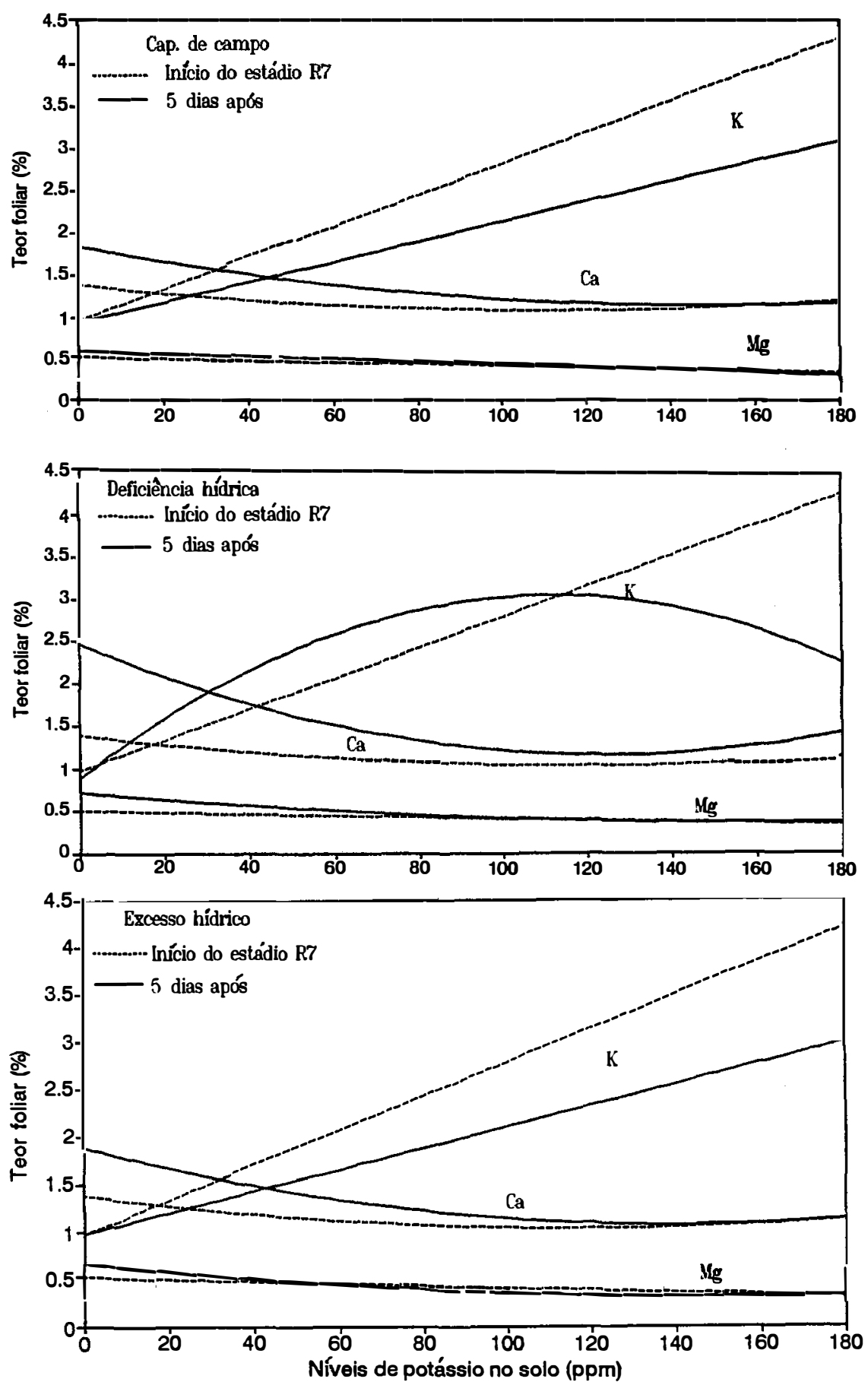

Figura 13. Curvas de regressão do teor foliar de $\mathrm{K}, \mathrm{Ca}$ e Mg para doses de potássio aplicadas ao solo, no inicio do estádio R7 e cinco dias após a aplicação de três niveis de água no solo (médias de quatro repetições). 
na disponibilidade do elemento no solo resultante da alteração da relação entre $\mathrm{K}$, Ca e Mg no solo. A adição de doses crescentes de potássio ao solo aumentou esta relação a valores mais adequados, propiciando maior produção com doses entre 122 e 132ppm (figura 14), diminuindo em alguns tratamentos os teores de Ca e Mg nas folhas (figuras 12 e 13) •

Na Figura 12 observa-se que o teor foliar de $\mathrm{K}$ e de Mg pouco variou nos cinco dias decorridos entre as análises no estádio R5, enquanto que na Figura 13, estádio R7, verifica-se uma tendência de queda, nos três regimes de água no solo, em função da translocação do nutriente para os frutos, por se tratar do início de enchimento de vagens (início do estádio R7).

Na Tabela 21 observa-se os teores foliares de cálcio. Em relação aos teores no início do estádio R5, houve aumento do teor de $\mathrm{Ca}$ para as plantas no solo em capacidade de campo (doses 0 e $120 \mathrm{ppm}$ de potássio) e no solo com deficiência hídrica (dose 120 ppm de potássio).

$$
\text { Em relação aos teores no início do estádio R7, }
$$

todos os tratamentos de fornecimento de água aumentaram o teor de cálcio nas folhas na dose oppm de potássio, e o tratamento no solo com deficiência hídrica aumentou o teor foliar de cálcio em todas as doses de potássio aplicadas ao solo. O crescimento do teor foliar de ca até fases finais do ciclo é esperado por ser um nutriente de baixa mobilidade 
Tabela 24. Equações de regressão e coeficientes de determinação dos teores foliares de $\mathrm{K}, \mathrm{Ca}$ e $\mathrm{Mg}$, para as doses de potássio aplicadas ao solo, em duas épocas de aplicação de três regimes de água no solo.

\begin{tabular}{|c|c|c|c|}
\hline Época & $\begin{array}{r}\text { Regime } \\
\text { de água }\end{array}$ & Equaçōes & $\mathrm{R}^{\wedge} 2$ \\
\hline $\begin{array}{l}\text { Início do R5 } \\
5 \text { dias após }\end{array}$ & $\begin{array}{l}\text { CC } \\
C C \\
\text { Def. } \\
\text { Exc. }\end{array}$ & $\begin{array}{l}Y=0,618+0,0180 X-0,00004 X^{\wedge} 2 \\
Y=0,909+0,0075 X \\
Y=1,024+0,0110 X \\
Y=0,868+0,0074 X\end{array}$ & $\begin{array}{l}0,97 \\
0,99 \\
0,99 \\
0,88\end{array}$ \\
\hline $\begin{array}{l}\text { Início do R7 } \\
5 \text { dias após }\end{array}$ & $\begin{array}{l}\text { CC } \\
\text { CC } \\
\text { Def. } \\
\text { Exc. }\end{array}$ & $\begin{array}{l}Y=0,976+0,0181 X \\
Y=0,950-0,00115 X \\
Y=0,886+0,0386 X-0,00017 X^{\wedge} 2 \\
Y=0,984+0,0113 X\end{array}$ & $\begin{array}{l}0,95 \\
0,78 \\
0,98 \\
0,81\end{array}$ \\
\hline
\end{tabular}

$\begin{array}{lclll}\text { Início do R7 } & \text { CC } & Y=1,385-0,0059 X+0,00002 X^{\wedge} 2 & 0,99 \\ 5 \text { dias após } & \text { CC } & Y=1,842-0,0099 X+0,000032 X^{\wedge} 2 & 0,98 \\ & \text { Def. } & Y=2,473-0,02124 X+0,000085 x^{\wedge} 2 & 0,96 \\ & \text { Exc. } & Y=1,886-0,0115 X+0,000041 X^{\wedge} 2 & 0,96 \\ & & & \\ & & - & & \\ \text { Início do R5 } & \text { CC } & Y=0,452-0,0019 X+0,000007 X^{\wedge} 2 & 0,96 \\ 5 \text { dias após } & \text { CC } & Y=0,574-0,00157 X & 0,88 \\ & \text { Def. } & Y=0,505-0,0008 X & 0,69 \\ & \text { Exc. } & Y=0,508-0,0031 X+0,000012 X^{\wedge} 2 & 0,99 \\ \text { Início do R7 } & \text { CC } & Y=0,502-0,0009 X & \\ 5 \text { dias após } & \text { CC } & Y=0,576-0,0015 X & 0,91 \\ & \text { Def. } & Y=0,720-0,0044 X+0,000013 X^{\wedge} 2 & 0,92 \\ & \text { Exc. } & Y=0,644-0,0044 X+0,000015 X^{\wedge} 2 & 0,99\end{array}$

(GALLO \& MIYASAKA, 1961).

Em relação à capacidade de campo cinco dias após o início do estádio $R 7$, as plantas em solo com deficiência hídrica apresentaram maiores teores foliares de Ca nas doses 0 e 180ppm de potássio. A saturação hídrica 
aplicada ao solo no estádio R5 diminuiu o teor foliar de $\mathrm{Ca}$, e não teve efeito para esta variável quando aplicada no estádio R7.

Não houve efeito da adição de potássio sobre o teor foliar de Ca para os tratamentos aplicados na época R5. As doses de potássio aplicadas ao solo afetaram significativamente os teores de cálcio nas folhas dos tratamentos na época R7 e os teores de magnésio nas folhas dos tratamentos nas épocas R5 e R7 (figuras 12 e 13, tabela 24).

Em relação aos teores iniciais das plantas no estádio R5, houve aumento de magnésio nas folhas na dose oppm de potássio para plantas cultivadas nos vasos em capacidade de campo (tabela 22).

Em relação aos teores iniciais das plantas no estádio R7, houve aumento do magnésio nas folhas na dose oppm dé potássio para plantas cultivadas em solo com deficiência e excesso de água.

Em alguns tratamentos, as doses de $\mathrm{K}$ aplicadas ao solo causaram um certo desequilíbrio entre os cátions, pois com $O$ aumento do teor de $\mathrm{K}$ nas folhas, houve diminuição dos teores de Ca e Mg.

o teor de enxofre foi pouco afetado pelos tratamentos estudados, tendo diminuído entre os dois estádios (tabela 23). 
72 .

4.8. Número de flores abertas

Os resultados obtidos para a floração estão na

Tabela 25.

Tabela 25. Número de flores abertas por planta (média de quatro repetições).

\begin{tabular}{|c|c|c|c|c|}
\hline Regime & & vive & Láss & \\
\hline água & 0 & 60 & 120 & 180 \\
\hline
\end{tabular}

----- Aplicação de água na época R5

$\begin{array}{lllll}\text { CC } & 6,4 \mathrm{a} & 7,0 \mathrm{a} & 6,8 \mathrm{a} & 7,6 \mathrm{a} \\ \text { Def. } & 7,3 \mathrm{a} & 8,3 \mathrm{a} & 8,0 \mathrm{a} & 8,6 \mathrm{a} \\ \text { ExC. } & 5,5 \mathrm{a} & 5,8 \mathrm{a} & 5,8 \mathrm{a} & 6,3 \mathrm{a}\end{array}$

\section{----- Aplicação de água na época R7}

$\begin{array}{llllll}\text { CC } & 5,4 \mathrm{a} & 6,3 \mathrm{a} & 7,6 \mathrm{a} & 6,3 \mathrm{ab} \\ \text { Def. } & 3,3 \mathrm{~b} & 3,8 \mathrm{~b} & 4,7 \mathrm{~b} & 4,8 \mathrm{~b} \\ \text { ExC. } & 5,1 \mathrm{ab} & 4,8 \mathrm{ab} & 6,6 \mathrm{ab} & 7,3 \mathrm{a}\end{array}$
Medias seguldas da mesma letra minuscula na coluna năo diferem significativamente entre sl pelo teste
de Duncan ao nivel de 58 de probabilidade.

Nos tratamentos com solo em capacidade de campo, o número de flores abertas por planta foi menor que valores encontrados na literatura. Em sete cultivares, BINNIE \& CLIFFORD (1981) encontraram de 14 a 20 flores abertas por planta e SILVEIRA et al. (1980) encontraram mais de seis flores abertas por dia, no pico de florescimento. É possível que as altas temperaturas $e$ as baixas umidades relativas registradas no decorrer da fase reprodutiva tenham afetado a produção de flores, pela redução no número de nós e, em 
conseqüência, diminuído o número de flores abertas.

o efeito de temperaturas elevadas sobre a abscisão de gemas florais foi verificado por KONSENS et al. (1991) e sabe-se que os feijoeiros crescem, em geral, em locais com pequena variação entre temperaturas máxima e mínima, sendo $21^{\circ} \mathrm{C}$ a temperatura ótima aparente para 0 florescimento (LAING et al., 1984). Em temperaturas médias elevadas, o desenvolvimento reprodutivo pode ser afetado, com falta de florescimento e queda de flores e vagens (MACK \& SINGH, 1969) .

Não houve efeito das doses aplicadas de potássio sobre o número de flores abertas por planta, em qualquer época ou nível de água aplicado ao solo.

A deficiência de água no solo diminuiu o número de flores abertas em relação ao tratamento com solo em capacidade de campo somente quando induzida na época $\mathrm{R7}$, ocasião em que poderia estar havendo prioridade para acúmulo de matéria seca na forma de grãos.

As plantas cultivadas em vaso com solo sob deficiência hídrica na época R7 também abriram significativamente menos flores que aquelas em vasos sob deficiência hídrica na época $\mathrm{R} 5$. Este resultado mostra a sensibilidade do estádio R7 à deficiência hídrica no solo, limitando a produção de flores quando já há vagens em formação na planta. HOSTALÁcio \& VÁlIo (1984) também obtiveram redução no número de flores estabelecidas em 
plantas cultivadas sob estresse hídrico nas fases de floração e frutificaçao.

A saturação hídrica do solo, na primeira ou segunda época, não afetou o número de flores abertas em cada planta.

4.9. Percentagem de abscisão de flores e vagens pequenas

Como foi pequeno o número de flores abertas, as plantas asseguraram sua produção reduzindo a queda de estruturas reprodutivas (tabela 26), com valor médio de $F=29 \%$ no experimento $(\mathrm{F} \%=$ percentagem de abscisão de flores e vagens pequenas). Em ambientes adequados, 60 a $70 \%$ das flores caem (LAING et al., 1984). Este processo normal de senescência pode decorrer da desvantagem de alguns tecidos na competição entre fonte e dreno, sendo então eliminadas flores anormais, com falhas na fertilização e/ou polinização, ou vagens mais velhas que abortam caso falte nitrogênio ou carboidratos.

Comparando-se os níveis de potássio aplicados às plantas em capacidade de campo (média das duas épocas de aplicação do tratamento), verifica-se que houve efeito da adição de potássio, com tendência a diminuir a queda de flores abertas e frutos pequenos. Neste caso, provavelmente ocorreu alguma desordem fisiológica para as plantas sem adubação potássica ( 0 ppm de $K$ ), com aumento nas concentrações 
Tabela 26. Percentagem de abscisão de flores e vagens pequenas $(\mathrm{F} \%)$, média de quatro repetições.

\begin{tabular}{|c|c|c|c|c|}
\hline \multirow{2}{*}{$\begin{array}{c}\text { Regime } \\
\text { de } \\
\text { água }\end{array}$} & \multicolumn{4}{|c|}{ Nivel de potássio } \\
\hline & 0 & 60 & 120 & 180 \\
\hline
\end{tabular}

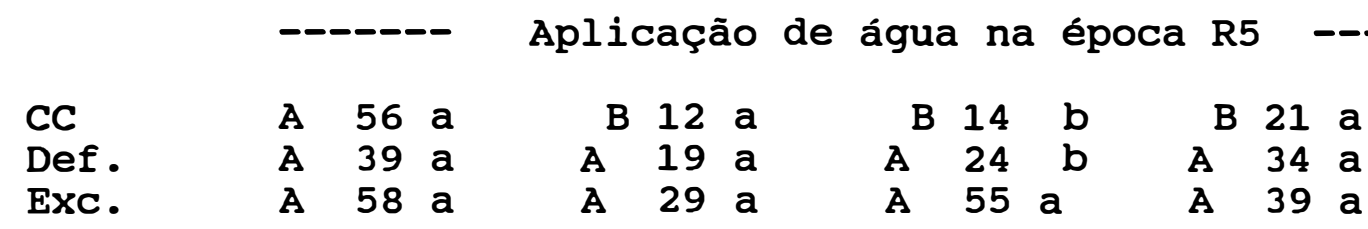

Aplicação de água na época R7 ------

\begin{tabular}{|c|c|c|c|c|c|c|c|c|c|c|c|}
\hline $\begin{array}{l}\text { CC } \\
\text { Def. } \\
\text { Exc. }\end{array}$ & $\begin{array}{l}A \\
A \\
A\end{array}$ & $\begin{array}{l}38 \\
42 \\
57\end{array}$ & $\begin{array}{l}a \\
a \\
a\end{array}$ & ${ }_{A}^{A}$ & $\begin{array}{r}16 \\
4 \\
32\end{array}$ & $\begin{array}{r}a b \\
b\end{array}$ & $\begin{array}{l}A \\
A B \\
A\end{array}$ & $\begin{array}{l}22 \\
25 \\
49\end{array}$ & $\begin{array}{l}\mathrm{b} \\
\mathrm{ab} \\
\mathrm{a}\end{array}$ & $\begin{array}{l}A \\
A B \\
A\end{array}$ & $\begin{array}{l}26 \quad b \\
27 \\
55 a^{b}\end{array}$ \\
\hline
\end{tabular}

Média das duas épocas --
CC
A $\quad 47$
B 14
B 18
B 24

Modias antecedidas da mesma letra maldscula na linha ou seguldas da mesma letra minuscula na coluna no diferes significativamente entre 81 pelo teste de Duncan ao nivel de 58 de probabilidade.

de ácido abscísico ( $A B A)$ e etileno, causando maior senescência $(\mathrm{F} \%)$. Este resultado está em desacordo com a possibilidade levantada por PORTES (1988) de que uma planta com deficiência nutricional produziria menos flores e menos vagens, de modo que o valor de $\mathrm{F} \%$ seria o mesmo que o de uma planta bem nutrida. Na Tabela 25 observa-se que não houve diferença entre tratamentos de potássio para o número de flores abertas. THOMAS \& HUNGRIA (1988) sugerem que 0 potássio estimula o transporte de assimilados aos frutos em desenvolvimento, o que os tornaria menos sensiveis ao aborto. 
Para os tratamentos com solo na capacidade de campo no início da fase reprodutiva (época R5) as plantas que apresentaram diminuição sensível no teor foliar de $\mathrm{K}$ tiveram menor pegamento de vagens (tabelas 20 e 26). Como no estádio R5 ainda ocorre intensa absorção de $\mathrm{K}$ (COBRA NETO et al., 1971), pode-se inferir que seja possível diminuir a queda de flores e vagens através da adubação potássica, ao se constatar baixos teores foliares nesse estádio do ciclo.

$\mathrm{Na}$ amostragem efetuada no início do estádio R7, persistiu o mesmo comportamento quanto à concentração foliar de $K$, e a concentração foliar de $N$ (tabela 18) foi maior no tratamento ao qual não se adicionou potássio (0ppm), onde houve intensa abscisão de flores e frutos, o que pode ter ocorrido em função do menor desenvolvimento das plantas, ou por um desbalanço fisiológico que induziu o acúmulo do nutriente nas folhas, uma vez que, na época da amostragem (quatro a seis dias após o início da abertura de flores), a planta já vinha mostrando queda intensa de flores e vagens, bem como formação de vagens chochas (figura 15).

A deficiência de água induzida ao solo, em qualquer época, não causou diferenças no valor de F\%, em relação ao tratamento com solo em capacidade de campo. DUBETZ \& MAHALLE (1969) não observaram abscisão em tratamentos de deficiência hídrica na pré-floração ou na floração. Contrariamente, HOSTALÁCIO \& VÁLIO (1984) observaram reduções elevadas no estabelecimento de frutos. A divergência nos 
resultados decorre da variação metodológica e ambiental nos diversos experimentos. O efeito de estresse depende, em grande parte, do efeito da demanda evaporativa e da tensão da água no solo sobre os processos reprodutivos, diferente para cada experimento.

Os niveis de potássio aplicados ao solo diminuíram levemente a abscisão de flores e vagens pequenas, para o tratamento com deficiência hídrica na época R7, destacando-se o nível 60ppm de potássio. Em relação à capacidade de campo, a saturação hídrica do solo na época R5 induziu elevada abscisão (F\%) no nível 120ppm de potássio, e na época R7 aumentou a abscisão nos níveis 120ppm e 180ppm de potássio aplicados ao solo, em função do maior número de flores destes tratamentos (tabela 25).

4.10. Número de vagens

o ponto de colheita foi desuniforme entre vagens e entre plantas; a colheita iniciou em 17/10/93 e foi encerrada em 04/11/93. Observou-se interação significativa entre os efeitos dos tratamentos estudados para o número de vagens maduras por planta (tabela 27).

No regime hídrico de capacidade de campo, a adição de doses de potássio elevou o número de vagens produzidas por planta, em conseqüência da menor abscisão nesses tratamentos (tabela 26). A produção de 4 a 5 vagens 
Tabela 27. Número de vagens maduras produzidas por planta (média de quatro repetições).

\begin{tabular}{|c|c|c|c|c|}
\hline \multirow{2}{*}{$\begin{array}{c}\text { Regime } \\
\text { de } \\
\text { água }\end{array}$} & \multicolumn{4}{|c|}{ Nível de potássio } \\
\hline & 0 & 60 & 120 & 180 \\
\hline
\end{tabular}

Aplicação de água na época R5

$\begin{array}{lllllllllllll}\text { CC } & \text { B } & 1,0 & \text { a } & \text { A } & 4,7 & \text { ab } & A & 4,8 & \text { a } & \text { A } & 5,0 & \text { a } \\ \text { Def. } & \text { B } & 0,9 & \text { a } & \text { A } & 5,7 & \text { a } & A & 5,3 & \text { a } & \text { A } & 4,6 & \text { a } \\ \text { ExC. } & \text { B } & 1,8 & \text { a } & \text { A } & 3,5 & \text { b } & \text { AB } & 2,4 & \text { b } & \text { AB } & 3,2 & \text { b }\end{array}$

$\begin{array}{lllllllllllll} & & & \text { Aplicação de água na época } & \text { R7 } & -\ldots \\ \text { CC } & \text { B } & 1,4 & \text { a } & \text { A } & 4,1 & \text { a } & \text { A } & 5,3 & \text { a } & \text { A } & 4,1 & \text { a } \\ \text { Def. } & \text { B } & 1,4 & \text { a } & \text { A } & 3,4 & \text { a } & \text { A } & 3,2 & \text { b } & \text { A } & 3,2 & \text { a } \\ \text { Exc. } & \text { B } & 1,4 & \text { a } & \text { A } & 2,9 & \text { a } & \text { A } & 2,6 & \text { b } & \text { A } & 3,2 & \text { a }\end{array}$
Medias antecedidas da mesma letra maldscula na linha ou seguidas da mesma letra minascula na coluna
ná diferem significativamente entre si pelo teste de Duncan ao nivel de 58 de probabilidade.

por planta foi inferior à produção obtida por SILVA (1981), de 20 vagens por planta, para o cultivar Carioca em condições de campo e sob temperaturas entre 16 e $29^{\circ} \mathrm{C}$.

Na época R5, a deficiência de água induzida ao solo não diferiu da capacidade de campo no seu efeito sobre - número de vagens, enquanto que no estádio R7 houve diminuição da variável no nível 120ppm de potássio aplicado ao solo.

Comparando-se a deficiência de água induzida ao solo nas duas épocas, R7 e R5, houve menor produção de vagens na segunda época, nos níveis 60 e 120ppm de potássio; entre estes estádios, MAGALHÃES et al. (1979) não observaram diferenças no número de vagens produzidas por planta. A 
adição de potássio aumentou o número de vagens nos tratamentos sob deficiência hídrica, independente da dose de potássio aplicada.

o excesso de água induzido ao solo no estádio R5 (nas doses 120 e 180ppm de potássio) diminuiu o número de vagens por planta em relação à capacidade de campo. Houve efeito do excesso de água aplicado durante o estádio R7 somente no nível $120 \mathrm{ppm}$ de potássio. A adubação com potássio aumentou levemente a produção de vagens nas plantas em solo saturado no estádio $\mathrm{R} 5$, com efeito mais visível no estádio R7 .

A percentagem de abscisão de flores e vagens pequenas praticamente foi igual nos tratamentos com deficiência hídrica induzida ao solo na pré-floração ou na formação de vagens (tabela 26) e por isso o número de flores abertas afetou o número de vagens maduras.

Verificou-se que o número de flores nas plantas em solo com deficiência hídrica na época $R 7$ foi significativamente menor que no estádio R5 (tabela 25), causando redução também significativa no número de vagens maduras produzidas nos níveis 60ppm e 120ppm de potássio aplicados ao solo (tabela 27).

o número de vagens chochas (que não formaram grãos) em alguns tratamentos foi bastante elevado (tabela 28). Para os tratamentos com solo em capacidade de campo, a adubação potássica reduziu a proporção de vagens chochas 
80.

produzidas. Em relação à capacidade de campo, no tratamento sob deficiência hídrica do solo na época R5, esta variável não foi afetada mas para o tratamento sob deficiência hídrica do solo na época $\mathrm{R7}$ e no nível 0ppm de potássio, houve efeito significativo.

Tabela 28. Percentagem de vagens chochas (média de quatro repetições ) .

\begin{tabular}{|c|c|c|c|c|}
\hline $\begin{array}{l}\text { Regime } \\
\text { de }\end{array}$ & & Iive & Eáss & \\
\hline água & 0 & 60 & 120 & 180 \\
\hline
\end{tabular}

Aplicação de água na época R5

$\begin{array}{lllllllrrr}\text { CC } & \text { A } & 70 & \text { a } & \text { B } 22 & & \text { B } 15 & & \text { B } 11 \\ \text { Def. } & \text { A } & 87 & \text { a } & \text { B } 11 & & \text { B } & 7 & & \text { B } 12 \\ \text { Exc. } & \text { A } & 10 & \text { b } & \text { A } & 8 & \text { A } & 2 & \text { A } & 5\end{array}$

Aplicação de água na época R7

\begin{tabular}{|c|c|c|c|c|c|c|c|}
\hline CC & A & 56 & $a$ & $\mathrm{AB} 2$ & B & 3 & B \\
\hline Def. & A & 14 & b & A & A & 4 & A \\
\hline Exc. & A & 19 & b & $A$ & A & 8 & A \\
\hline
\end{tabular}

CC
A 63
B 22
B 9
B 10 MGdlas antecedidas da mesma letra maluscula na linha ou seguldas da mesma letra minuscula na coluna
nóo diferem significativamente entre si pelo teste de Duncan ao nivel de 58 de probabilidade.

Comparando-se os tratamentos de deficiência hídrica do solo nas duas épocas, houve efeito significativo para o estádio R7, onde diminuiu a percentagem de vagens chochas em relação ao estádio R5, porém somente no nível oppm de potássio. A adição de doses de potássio ao solo afetou os tratamentos sob deficiência hídrica do solo na época R5. 
Nos tratamentos com solo saturado, nas duas épocas, houve menor número de vagens chochas proporcionalmente ao tratamento com solo em capacidade de campo, no nivel oppm de $\mathrm{K}$.

4.11. Número de sementes por vagem

Na Tabela 29 encontram-se os resultados obtidos para o número de sementes produzidas por vagem. Não houve qualquer efeito significativo dos tratamentos sobre esta variável pois as variações ambientais afetam a produção, mais comumente, através do número de vagens formadas do que do número de sementes por vagem (GOLDSWORTHY, 1984). Com efeito, a produção de sementes por vagem variou de 3,5 a 6 , valores semelhantes aos encontrados por BINNIE \& CLIFFORD (1981) e SILVEIRA et al. (1980) para outros cultivares, e por SILVA (1981) para o cultivar Carioca.

4.12. Matéria seca dos grãos

Houve interação tríplice significativa entre os fatores estudados para esta variável (tabela 30).

A deficiência de água no solo no estádio R5 não afetou a produção de grãos, em relação ao solo em capacidade de campo, em qualquer dose de potássio aplicada ao solo, apesar das plantas apresentarem-se mais desenvolvidas. 
Tabela 29. Número de sementes produzidas por vagem (média de quatro repetições).

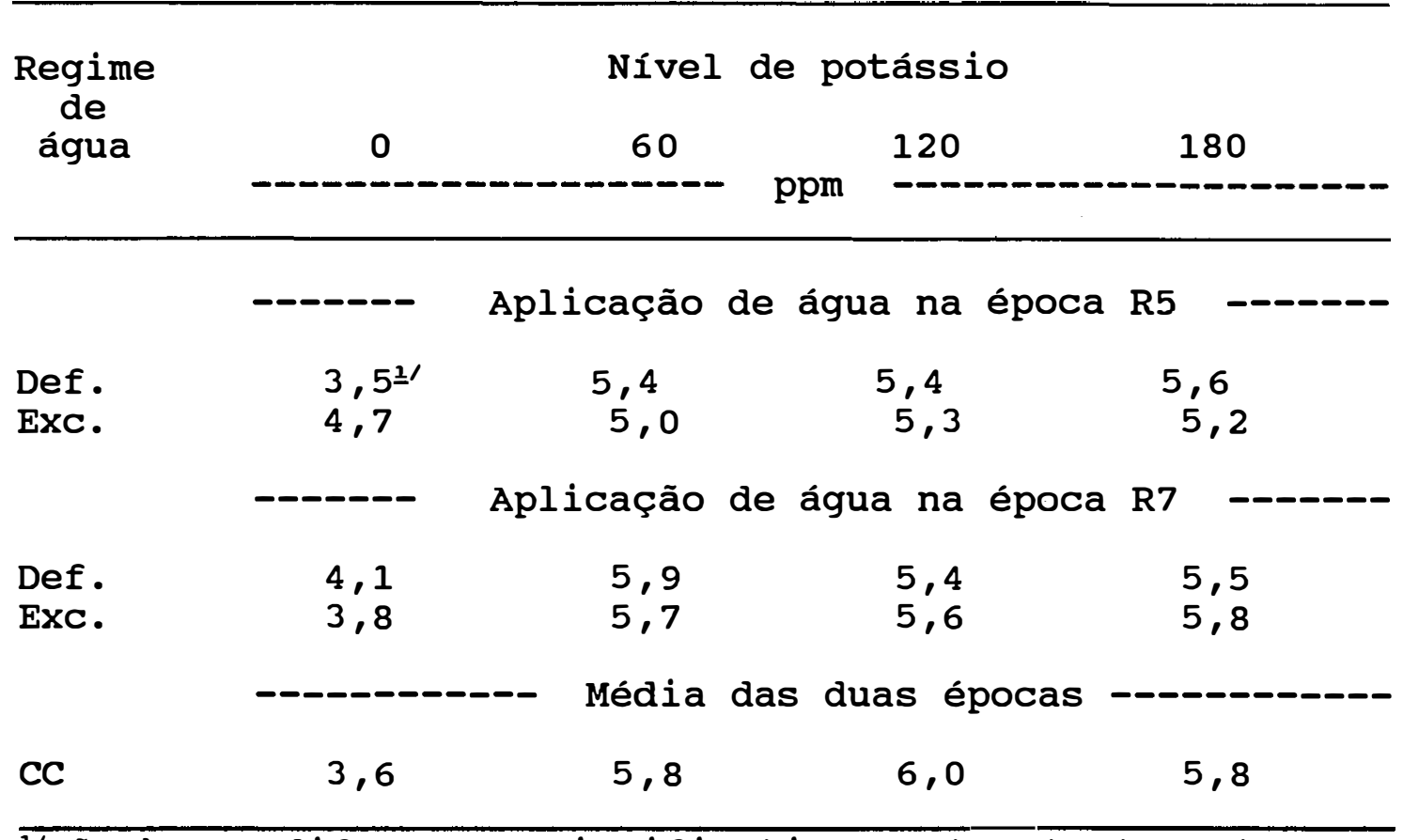

I’Não houve diferenças significativas entre tratamentos.

Como em plantas sob estresse hídrico ocorre redução da matéria seca acumulada (BERGAMASCHI et al., 1988; LOPES et al., 1986), seria esperado um efeito sobre a produção de sementes, o qual não ocorreu. Apesar do porte menor alcançado nos tratamentos sob deficiência hídrica do solo no estádio R5 (figura 7), a matéria seca da parte aérea e de raízes das plantas não foi afetada (tabelas 16 e 17) nesse estádio. Pode-se supor que o aumento no período de crescimento até o florescimento (tabela 4) e o mesmo uso de água que as plantas cultivadas em solo sem deficiência hídrica (tabela 8) tenham possibilitado a recuperação da 
Tabela 30. Produtividade de matéria seca dos grãos ( $\mathrm{g} / \mathrm{planta}$, média de quatro repetiçōes).

\begin{tabular}{ccccc}
\hline $\begin{array}{l}\text { Regime } \\
\text { de }\end{array}$ & \multicolumn{4}{c}{ Nivel de potássio } \\
água & 0 & 60 & 120 & 180 \\
& - & & ppm & - \\
\hline
\end{tabular}

------ Aplicação de água na época R5 ------

$\begin{array}{lllllllllllll}\text { CC } & \text { B } & 0,24 & \text { a } & \text { A } & 4,41 & \text { a } & \text { A } & 4,61 & \text { a } & \text { A } & 4,38 & \text { a } \\ \text { Def. } & \text { B } & 0,10 & \text { a } & \text { A } & 3,56 & \text { ab } & \text { A } & 3,94 & \text { a } & \text { A } & 3,49 & \text { a } \\ \text { ExC. } & \text { B } & 0,98 & \text { a } & \text { A } & 2,48 & \text { b } & \text { AB } & 1,77 & \text { b } & \text { A } & 2,29 & \text { b }\end{array}$

------ Aplicação de água na época R7 ------

$\begin{array}{lllllllllllll}\text { CC } & \text { B } & 0,28 & \text { a } & \text { A } & 3,70 & \text { a } & \text { A } & 4,44 & \text { a } & \text { A } & 3,99 & \text { a } \\ \text { Def. } & \text { B } & 0,50 & \text { a } & \text { A } & 3,24 & \text { ab } & \text { A } & 2,81 & \text { b } & \text { A } & 2,94 & \text { ab } \\ \text { ExC. } & \text { B } & 0,46 & \text { a } & \text { A } & 2,55 & \text { b } & \text { A } & 2,35 & \text { b } & \text { A } & 2,61 & \text { b }\end{array}$

Medias antecedidas da mesma letra maloscula na linha ou seguldas da mesma letra minuscula na coluna
ná diferem signif 1 cativamente entre 81 pelo teste de buncan ao nivel de $5 \%$ de probabilidade.

produção de fotoassimilados utilizados na produção de grãos, indicando alguma capacidade de recuperação das plantas.

Segundo LAING et al. (1984), o aumento do ciclo vegetativo proporciona um maior equilíbrio de assimilados entre as folhas ("fonte") e as vagens ("dreno"). Esta recuperação das plantas sob deficiência hídrica do solo no estádio R5 é inferida também quando se observa que o número de flores abertas (tabela 25) e a abscisão de órgãos reprodutivos (tabela 26) não variaram em relação às plantas em solo sob capacidade de campo. Nesse caso, a avaliação do crescimento das plantas através da medida da altura não foi um bom indicador de sua recuperação (tabela 13, figura 7), uma vez que a altura é função de outros componentes básicos: 
número de nós e comprimento de entrenós.

No estádio R7, a deficiência hídrica induzida ao solo diminuiu a matéria seca dos grãos apenas no nível 120 ppm de potássio, apesar de na época R7, em que a deficiência foi induzida, encontrar-se dentro do período considerado crítico (zero a 15 dias a partir da floração) para o componente número de vagens (LAING et al., 1984) e, em conseqüência, para a produção. Mesmo com reduzida utilização de água durante 0 estádio R7 (tabela 9) e o menor número de flores abertas (tabela 25), os tratamentos com deficiência de água no solo na época R7 e adubados com 60ppm e 180ppm de potássio não produziram menos vagens (tabela 27). Provavelmente houve maior eficiência no uso água pela planta em seus processos fisiológicos durante este estádio, em relação às plantas em solo sob capacidade de campo.

Como a deficiência hídrica induzida ao solo teve mesma duração, com o solo atingindo potenciais de água semelhantes nas duas épocas (figura 4 ) e a a produção média não foi afetada, pode-se considerar que a indução de seca no solo nas épocas R5 ou R7 não foi crítica para as plantas.

Segundo BOYER \& MCPHERSON (1975), os processos fisiológicos de importância na formação dos grãos possuem diferentes sensibilidades à deficiência hídrica. Neste trabalho, os potenciais de água no solo nos periodos de deficiência hídrica podem não ter sido suficientemente baixos a ponto de afetar irreversivelmente algum destes processos. 
Comparando-se as duas épocas de indução de deficiência de água no solo, a época R7 induziu produção 29\% menor que a época R5, na dose 120ppm de potássio (tabela 30 ). Além deste resultado, a menor produção de flores (tabela 25) e o menor número de vagens produzidas (tabela 27) na época R7, em relação à época R5, refletiu-se também em tendência de uma menor produção dos tratamentos com níveis de 60ppm (redução de 9\%) e 180ppm (redução de 16\%) de potássio aplicado ao solo (tabela 30), mostrando que a época R7 foi mais crítica à deficiência hídrica no solo que a época R5.

o excesso de água no solo foi prejudicial, em relação à capacidade de campo, nas épocas R5 e R7, nas doses 60, 120 e 180ppm de potássio. LAKITAN et al. (1992) também obtiveram baixas produções para plantas em solo inundado, antes ou após o florescimento.

Considerando-se os níveis de água aplicados ao solo, houve resposta quadrática às doses de potássio aplicadas, independente da época de aplicação dos tratamentos (figura 14). As doses de potássio estimadas para maior produção de matéria seca de grãos foram de 126, 122 e 132ppm, estimando-se para a produtividade de 200.000 plantas por hectare os valores de 940,837 e $488 \mathrm{~kg} / \mathrm{ha}$ para os tratamentos com solo em capacidade de campo, com deficiência hidrica no solo e com excesso hidrico no solo, respectivamente. A maior produtividade obtida no experimento representa cerca de $30 \%$ do potencial produtivo do cultivar em 
86.

condições de campo. Tais resultados ressaltam o risco existente na extrapolação direta de resultados de experimentos em vasos em casa de vegetação para o plantio a campo, pois as complexas relações solo-planta-atmosfera são amplamente distintas entre as duas situações.

Para as doses estimadas de potássio que induziram maior resposta nas variáveis estudadas, verifica-se que a lâmina de água aplicada nos tratamentos em capacidade de campo e deficiência hídrica foi a que mais se aproximou da dose correspondente à maior produção de matéria seca de grãos (faixa de 120 a $140 \mathrm{ppm}$ de $\mathrm{K}$ ); no tratamento com deficiência hídrica induzida ao solo, a matéria seca de raízes também teve dose mais próxima à maior produção de grãos e no tratamento com excesso hídrico no solo, a matéria seca produzida pela parte aérea foi a variável que teve resposta quadrática, tal como a matéria seca de grãos.

A massa seca estimada de 100 sementes para os tratamentos pode ser vista na Tabela 31.

A adubação potássica teve efeito significativo em todos os regimes de água, aplicados nas duas épocas. o tamanho das sementes, comumente expresso pela massa seca de 100 sementes, variou entre 11,7 e $17,1 \mathrm{~g}$. Estes valores encontram-se abaixo da faixa obtida para o cultivar Carioca, 15 a $35 \mathrm{~g}$.

Para o regime hídrico de deficiência, houve diferença significativa apenas comparando-se o nível oppm de 


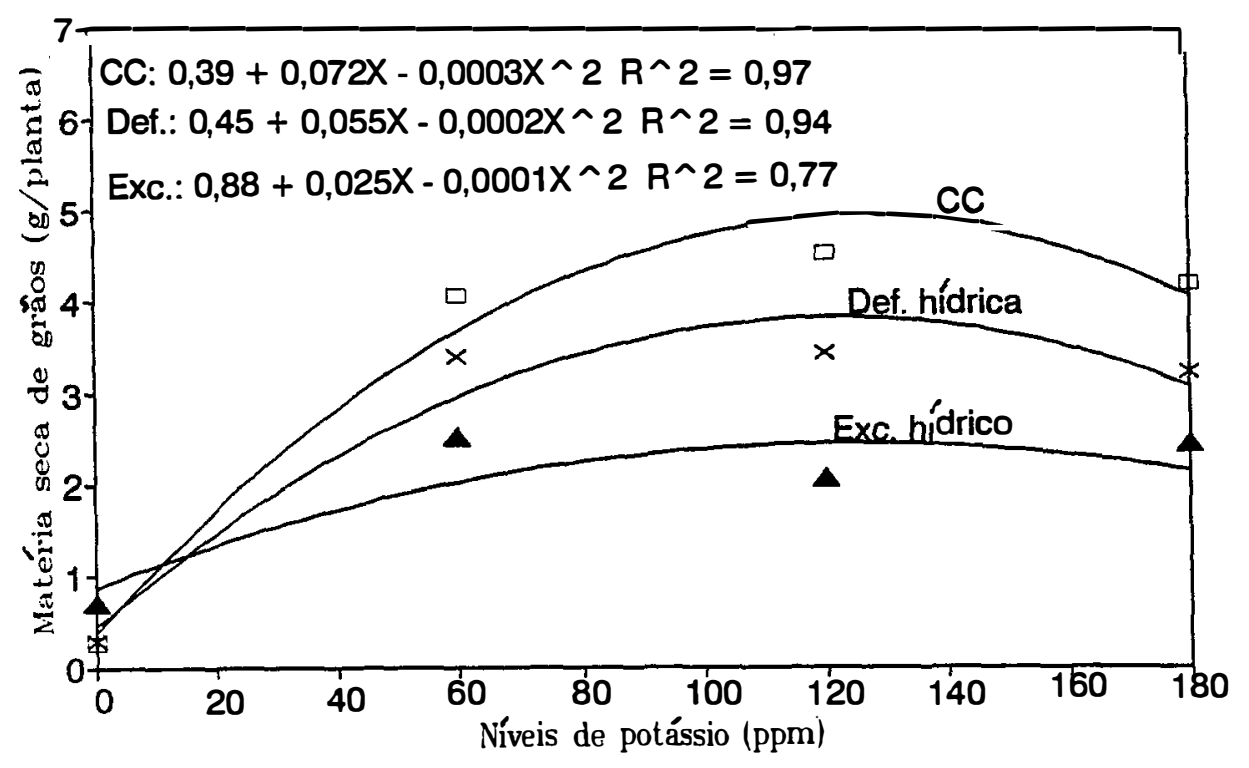

$\square$ CC $\times$ Def. $\triangle$ Exc.

Figura 14. Curvas de regressão e coeficientes de determinação $\left(R^{\wedge} 2\right)$ da matéria seca produzida pelos grãos para doses de potássio aplicadas ao solo, em três regimes de água no solo (médias de quatro repetições ) .

potássio entre as duas épocas de aplicação de água. FIEGENBAUM et al. (1991) também não obtiveram massas distintas de sementes para plantas com estresse de água durante 15 dias na floração. Segundo LAING et al. (1984), o componente tamanho de semente é afetado apenas quando há interferências mais tardias nos processos fisiológicos, a partir de 22 dias após o florescimento.

Para o regime de excesso de água no solo, o tamanho das sementes foi superior em relação ao tratamento com solo em capacidade de campo, na época R5 e no nível oppm 
Tabela 31. Produção de matéria seca de 100 sementes ( 9 , média de quatro repetições).

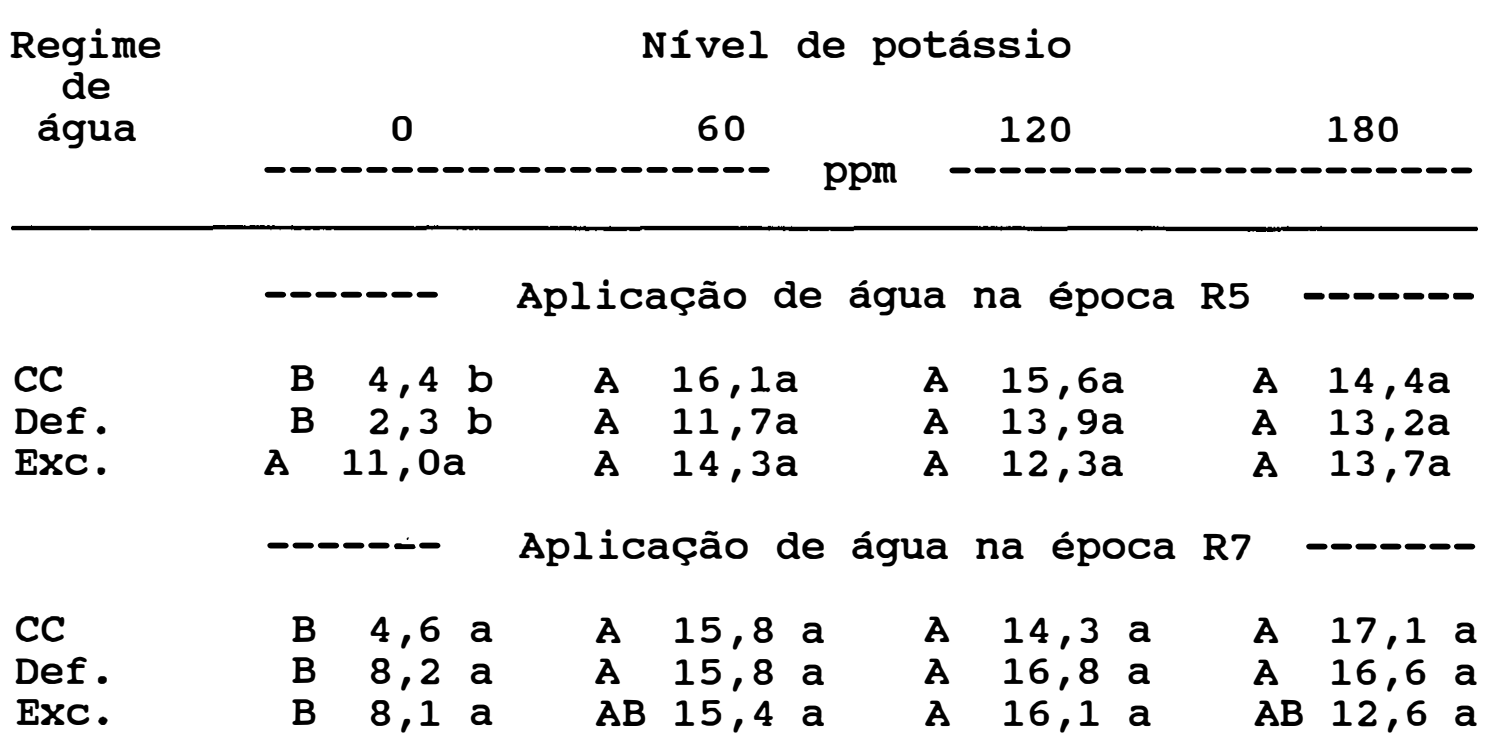

Medias antecedidas da mesma letra maluscula na linha ou seguldas da mesma letra minuscula na coluna Hedias antecedidas da mesma letra maidscula na linha ou seguidas da mesma letra minuscula na col
nao diferem significativanente entre 81 pelo teste de Duncan ao nivel de 58 de probabilidade.

de potássio.

4.13. Padrão de florescimento e produção

A distribuição acumulada das flores produzidas no período de florescimento de cada tratamento, o número total acumulado de vagens e o número acumulado de vagens chochas correspondentes podem ser vistos nas figuras a seguir.

Na Figura 15 apresenta-se o número acumulado de flores abertas e vagens produzidas no tratamento em capacidade de campo, nas quatro doses de potássio aplicadas ao solo. A floração perdurou de 15 a 27 dias nos tratamentos 

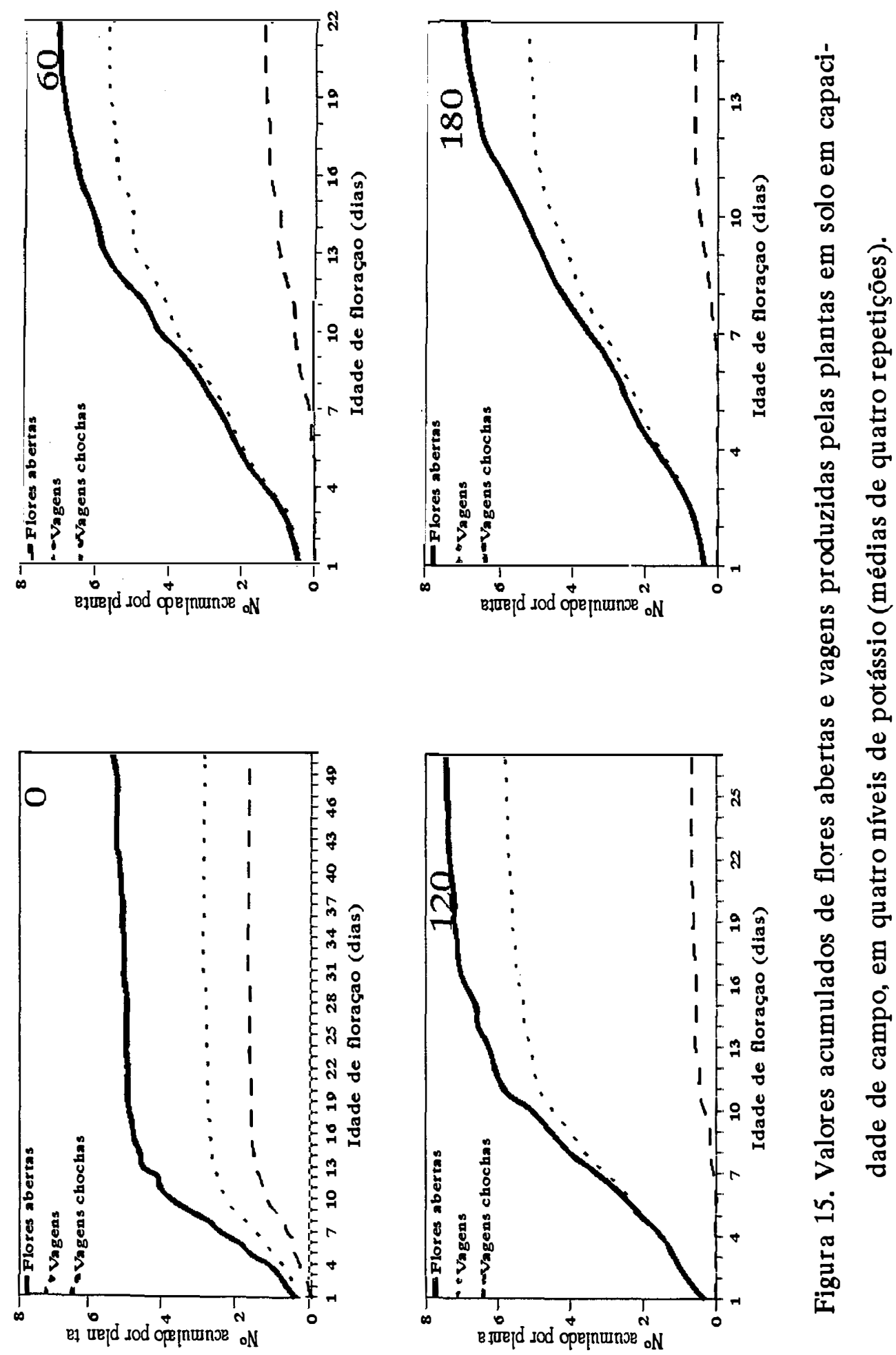
onde se adicionaram doses de potássio, com maior produção de flores a partir do quarto dia da abertura da primeira flor e duração do pico de florescimento variável com a dose de potássio.

O maior número de vagens maduras originou-se de flores abertas entre a primeira e segunda semanas após abertura da primeira flor. Observa-se que as primeiras flores abertas produziram mais vagens maduras com sementes (menor incidência de vagens chochas).

O feijoeiro apresentou maior produção de flores que de frutos maduros, como ocorre com outras leguminosas (BINNIE \& CLIFFORD, 1981; SUBHADRABANDHU et al., 1978), e as flores que abriram no início da floração foram as que mais participaram da produção de vagens maduras, tal como foi observado por vários autores (SMITH \& PRYOR, 1962; RAMALHO \& FERREIRA, 1979; WEAVER et al., 1984; SILVEIRA et al., 1980). Um comportamento típico de cultivares com hábito de crescimento indeterminado é o vingamento quase completo de vagens oriundas das primeiras flores abertas, seguido de alta taxa de abscisão de flores abertas mais tarde (LAING et al., 1984), devido à mobilização preferencial de fotoassimilados para as estruturas reprodutivas formadas em primeiro lugar, com a abscisão associada àquelas formadas posteriormente. Esta abscisão pode alcançar 45 a $80 \%$ (BINNIE \& CLIFFORD, 1981; SILVEIRA et al., 1980).

Neste trabalho, houve pequena abscisão de 
flores, a produção de flores por planta foi reduzida e as plantas utilizaram-nas quase que totalmente para assegurar a produção, e por isso, não ficou tão evidente esse padrão de florescimento, embora seja possível observar uma tendência neste sentido. Apesar do potencial de vagens produzidas por planta deste cultivar chegar a 20 (SILVA, 1981) e das plantas terem apresentado pequeno número de flores abertas, ainda assim houve abscisão, embora pequena, e a formação de muitas vagens chochas, o que denota a competição interna, principal causa de perdas significativas de estruturas reprodutivas (gemas florais, flores abertas, vagens imaturas) em leguminosas (GOLDSWORTHY, 1984).

No tratamento sem aplicação de potássio ao solo, a floração perdurou 51 dias, porém a principal produção originou-se de flores abertas até $013^{\circ}$ dia, de forma semelhante à dos tratamentos adubados. Neste tratamento, houve florescimento tardio, e menor vingamento das primeiras flores produzidas, em relação às plantas adubadas, provavelmente devido à maior concorrência entre as flores e frutos em desenvolvimento.

o período de formação de vagens foi de 29 dias para o nível oppm de potássio aplicado ao solo, 22 dias para o de 60ppm de potássio, 27 dias para o de 120ppm de $\mathrm{K}$ e de 15 dias para o nível de 180ppm de $K$. A concentração do florescimento no nível 180ppm de potássio aplicado ao solo é um fator de risco para a produção das plantas, o qual não foi 
compensado pela antecipação na maturação (tabela 7) ou melhor produção (tabela 30, figura 14).

A proporção de flores abertas que não formaram vagens maduras é influenciada por uma grande quantidade de fatores ambientais e bióticos. LAING et al. (1984) citam as doenças, insetos, vento, deficiência mineral, deficiência interna de água e temperatura como podendo afetar sensivelmente a abscisão de estruturas reprodutivas. A inadequada nutrição das plantas foi referida por WOLF (1942), que avaliou, antes da colheita, plantas com bom e mau pegamento de vagens, obtendo uma relação entre os teores de nutrientes e o vingamento de vagens.

Na Figura 16 apresenta-se a produção de flores, o vingamento e o chochamento de vagens no tratamento com deficiência hídrica induzida ao solo na época R5 (valores acumulados). O tratamento sem aplicação de potássio ao solo mostrou um longo período de florescimento, como ocorreu no tratamento em capacidade de campo, sendo que $87 \%$ de suas vagens estabelecidas apresentaram chochamento (tabela 28). Observa-se que a deficiência hídrica do solo na época R5 causou um ligeiro aumento na alternância diária de produção de flores, vista na Figura 16 como patamares onde não ocorreu a abertura de flores, nas doses menores de potássio aplicadas ao solo. A distribuição das flores abertas no tempo variou nos níveis 120 e $180 \mathrm{ppm}$ de $\mathrm{K}$ em relação ao comportamento do tratamento em capacidade de campo. No nível 

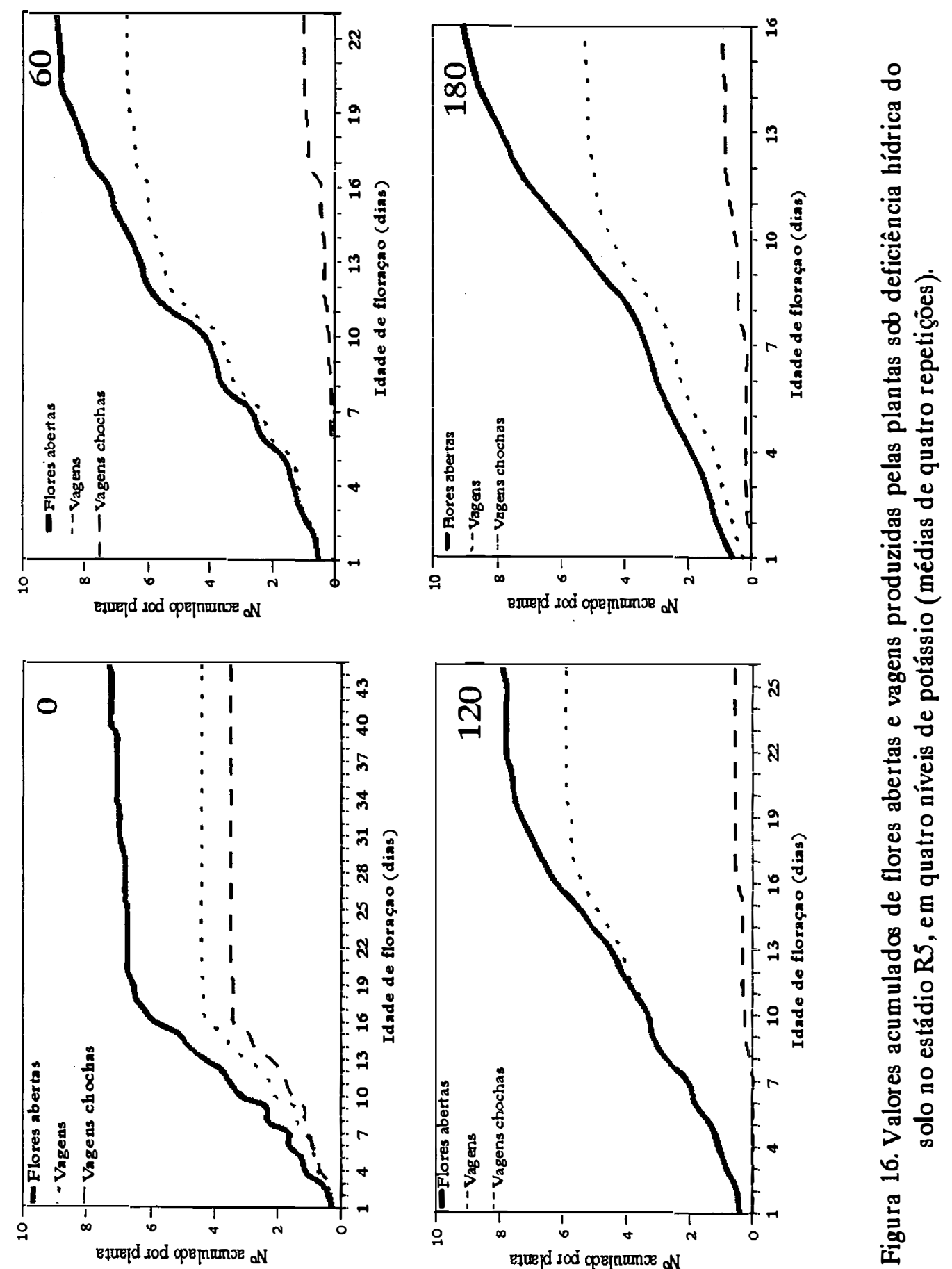
$120 \mathrm{ppm}$ de $\mathrm{K}$, a produção foi mais constante ao longo de todo - período de florescimento. Já no nível 180ppm de $\mathrm{K}$ houve aumento na produção de flores a partir do oitavo dia até o final do florescimento, época em que a produção já decrescia nesse mesmo nível de potássio, para as plantas em capacidade de campo.

Para os tratamento com 60,120 e $180 \mathrm{ppm}$ de $\mathrm{K}$ aplicados ao solo, o comportamento das plantas seguiu uma tendência semelhante à das plantas em capacidade de campo, quanto à percentagem de abscisão de flores e vagens pequenas e à formação de vagens chochas. o período de formação de vagens foi de 20 dias para os níveis 0,60 e $120 \mathrm{ppm}$ de potássio aplicado ao solo, e de 15 dias para o nível 180ppm de $K$. A redução no período de abertura de flores e o pegamento de vagens que ocorreu ao nível 180ppm $\mathrm{K}$ em capacidade de campo, quando relacionado com os níveis 60 e $120 \mathrm{ppm} K$, persistiu no tratamento com solo sob deficiência hídrica na época R5.

Na Figura 17 observa-se a produção acumulada de flores e vagens no tratamento com deficiência hídrica induzida ao solo na época R7. Neste tratamento, ocorreu florescimento tardio quando se adicionou $180 \mathrm{ppm}$ de $\mathrm{K}$ ao solo, e houve encurtamento do período de florescimento nos níveis o e 60ppm de $\mathrm{k}$, em relação aos tratamentos com solo em capacidade de campo. 

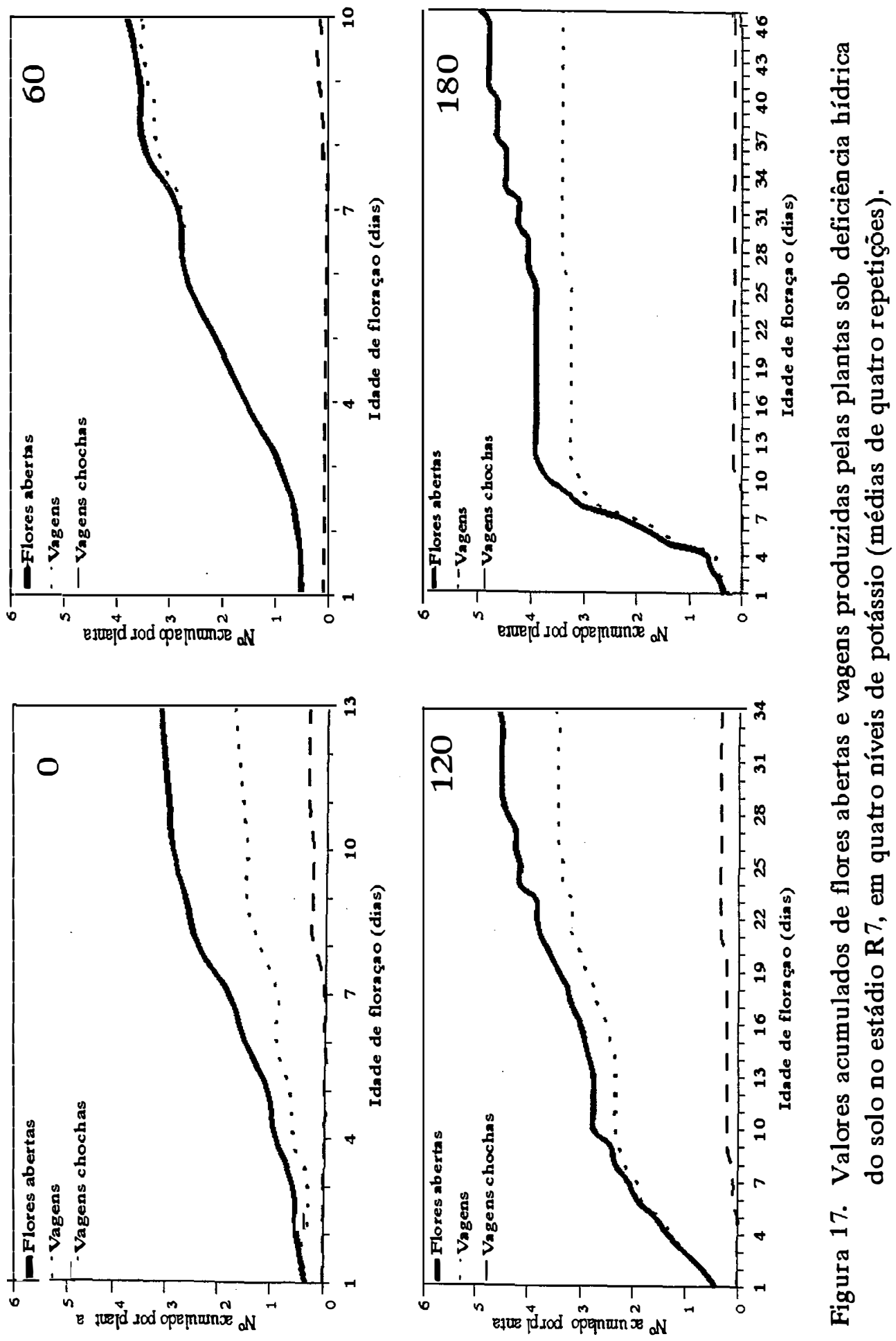
No nível oppm de potássio adicionado ao solo, persistiu um menor pegamento das primeiras flores produzidas. No nível 60ppm de $K$, todas as flores produzidas até o sexto dia de florescimento produziram vagens. Nos niveis 60 e $120 \mathrm{ppm}$ de $\mathrm{K}$, as vagens que vingaram foram as provenientes de flores produzidas ao longo de todo o florescimento, de uma maneira um pouco distinta da tendência observada nos tratamentos com solo em capacidade de campo e sob deficiência hídrica na época R5 (figuras 15 e 16). Esse comportamento é normal, segundo BINNIE \& CLIFFORD (1981), que verificaram que as flores abertas tardiamente são geneticamente capazes de produzir vagens e só não o fazem, em condições normais, por uma limitação no suprimento de fotoassimilados ou outros nutrientes, uma influência hormonal, ou ambos.

Como na análise foliar não se observou qualquer alteração nos teores de N, P, K, Ca, Mg e S dos tratamentos com solo sob deficiência hídrica na época $\mathrm{R7}$ em relação aos tratamentos em capacidade de campo, houve provavelmente alguma alteração metabólica induzida pelo tratamento, nesses níveis de adubaçao potássica.

Ainda na Figura 17, no nivel 120ppm de $K$, observa-se um novo surto de florescimento, iniciando-se aos dez dias da floração inicial; no nível 180ppm de $K$, houve florescimento tardio, onde poucas flores abriram, com um pegamento de vagens pouco significativo. 
Comparando-se os niveis de potássio aplicados ao solo no tratamento com deficiência de água no solo na época R7, houve grande variação na amplitude do florescimento. O nivel 60ppm de $\mathrm{K}$ mostrou um periodo curto, de apenas 10 dias, o que pode tornar a produção muito suscetivel a qualquer outro fator danoso que ocorra junto com a deficiência hídrica do solo. No nível 120ppm de $\mathrm{K}$, o tratamento permitiu uma faixa mais larga de tempo para emissão de flores, embora com menor número de flores abertas por dia, o que pode ser considerado uma vantagem, pois a produção e seus componentes não foram afetados, em relação aos níveis 60 e 180ppm $K$.

No nivel 180ppm de $K$, embora com floração prolongada, as flores que produziram vagens abriram nos primeiros 13 dias, numa situação semelhante à do tratamento 60ppm de $\mathrm{K}$.

$\mathrm{Na}$ Figura 18, apresentam-se os resultados para - tratamento com solo saturado na época R5. Nos tratamentos aos quais foram adicionadas as doses de 60,120 e 180ppm de $\mathrm{K}$ houve prolongamento do período total de florescimento, em relação à capacidade de campo, chegando a ter entre 31 e 37 dias. Não houve concentração da produção de flores ao longo do periodo de florescimento, com ocorrência de um pico melhor definido apenas no nivel 120ppm de $\mathrm{K}$.

Em todos os níveis de potássio, observa-se a ocorrência de vários fluxos de abertura de flores em períodos 

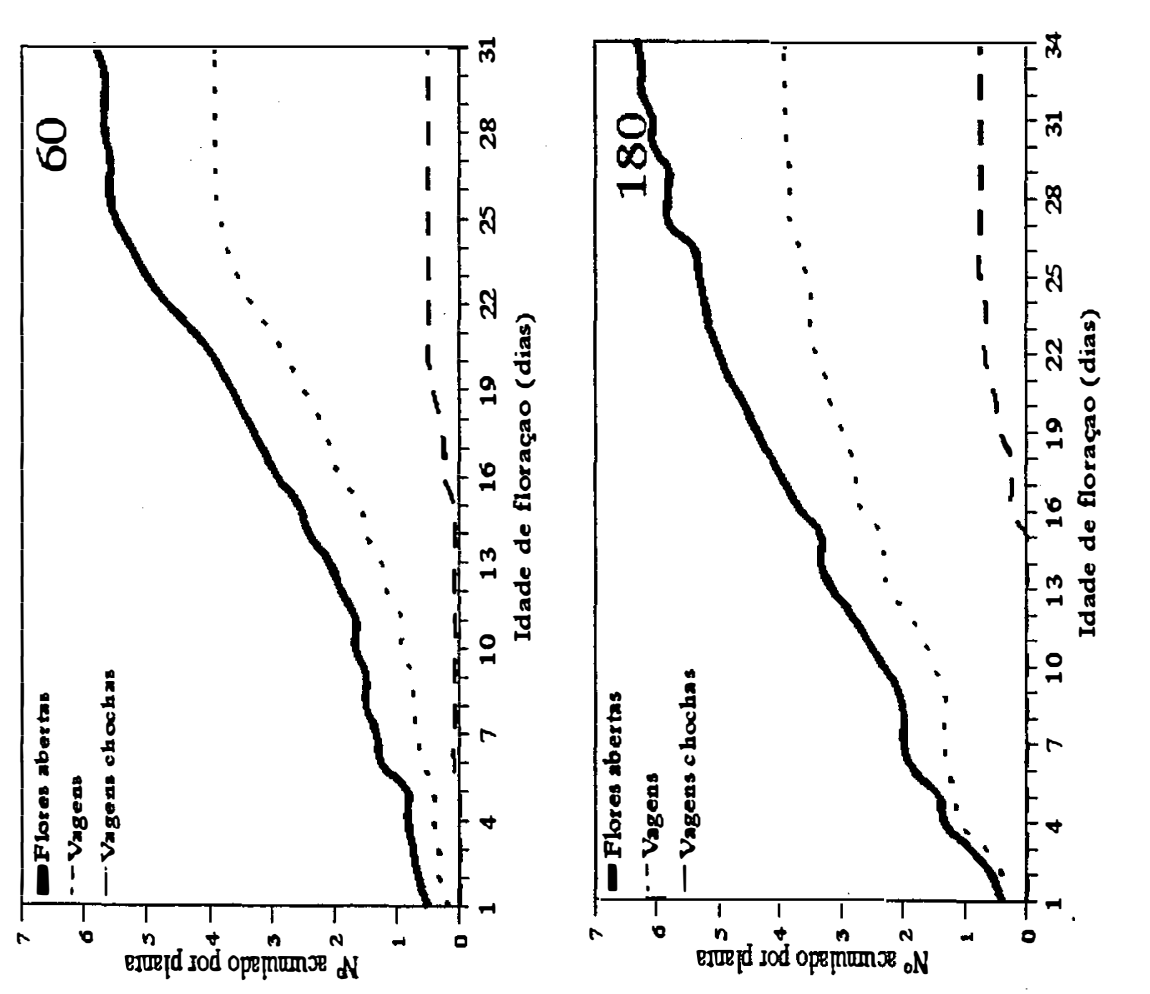

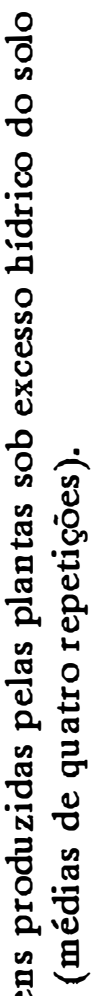
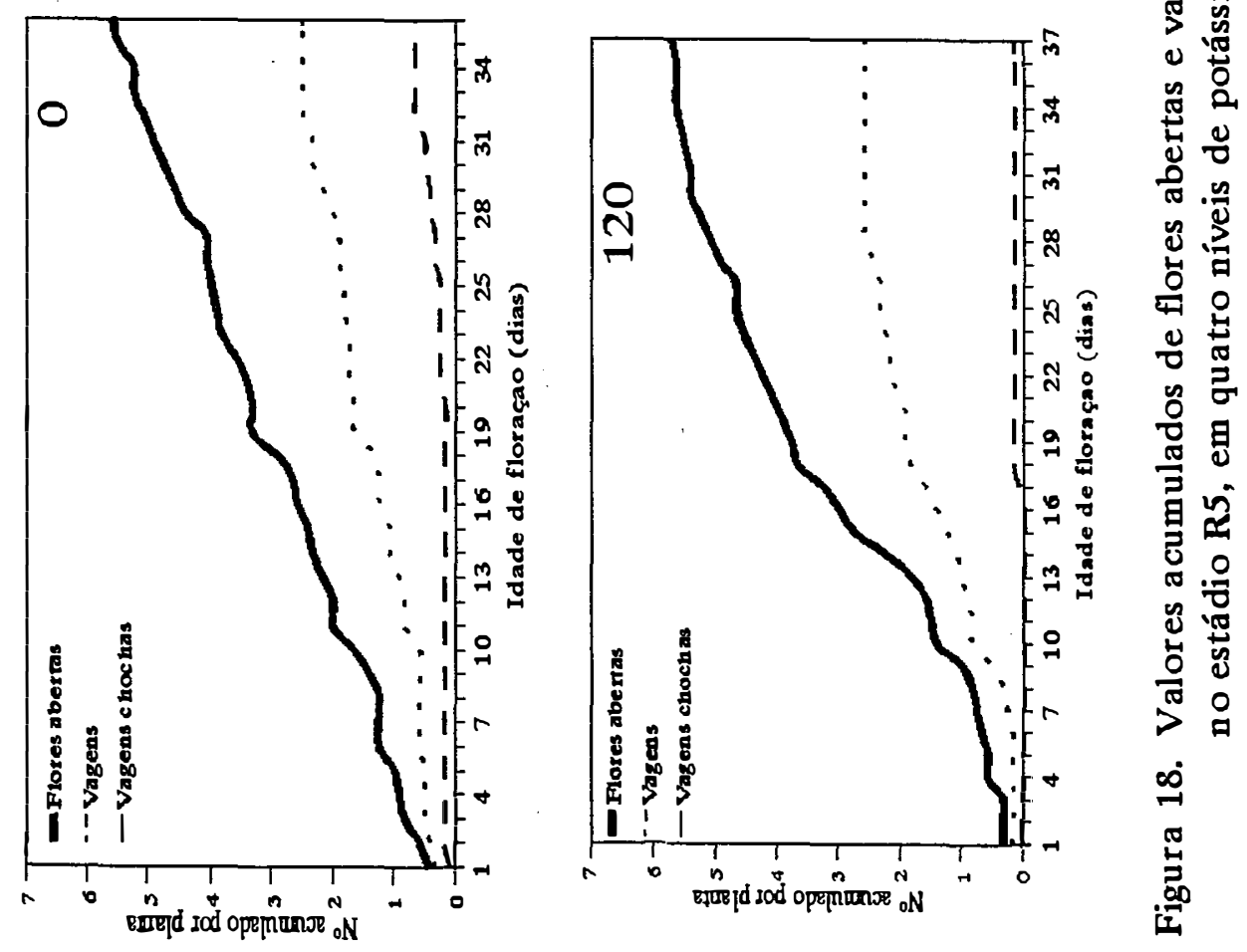
curtos de poucos dias. No tratamento $60 \mathrm{ppm}$ de $\mathrm{K}$ houve um período mais estável de produção de flores, entre $012^{\circ} \mathrm{e} 0$ $26^{\circ}$ dia; no tratamento $120 \mathrm{ppm}$ de $\mathrm{K}$ esta estabilidade foi menos evidente $\left(13^{\circ}\right.$ ao $18^{\circ}$ dia) e no tratamento $180 \mathrm{ppm}$ de $\mathrm{K}$ houve dois períodos em que não cessou a abertura floral (10 ao $13^{\circ}$ e $16^{\circ}$ ao $23^{\circ}$ dias).

Não houve maior pegamento de vagens oriundas das primeiras flores abertas no tratamento de excesso hídrico do solo na época R5, como conseqüência da alteração do comportamento no florescimento em relação aos tratamentos em capacidade de campo. Em geral, as vagens chochas corresponderam às flores abertas no meio do período de florescimento.

Na Figura 19, apresentam-se os resultados para os tratamentos com solo sob excesso de água na época R7. Em relação ao comportamento em capacidade de campo (figura 15), houve redução significativa no período de florescimento no nível 0ppm de $K$. No nível 180ppm de $K$, o comportamento reprodutivo estudado foi bastante semelhante nos dois tratamentos (saturado na época $\mathrm{R7}$ e capacidade de campo). Considerando-se a distribuição das flores produzidas, observa-se que nos niveis 60 e $120 \mathrm{ppm}$ de $\mathrm{K}$ adicionado ao solo houve florescimento tardio e tendência a fluxos no florescimento, tal como foi observado nos tratamentos sob excesso de água em pré-floração (época R5), porém com amplitude menor. 

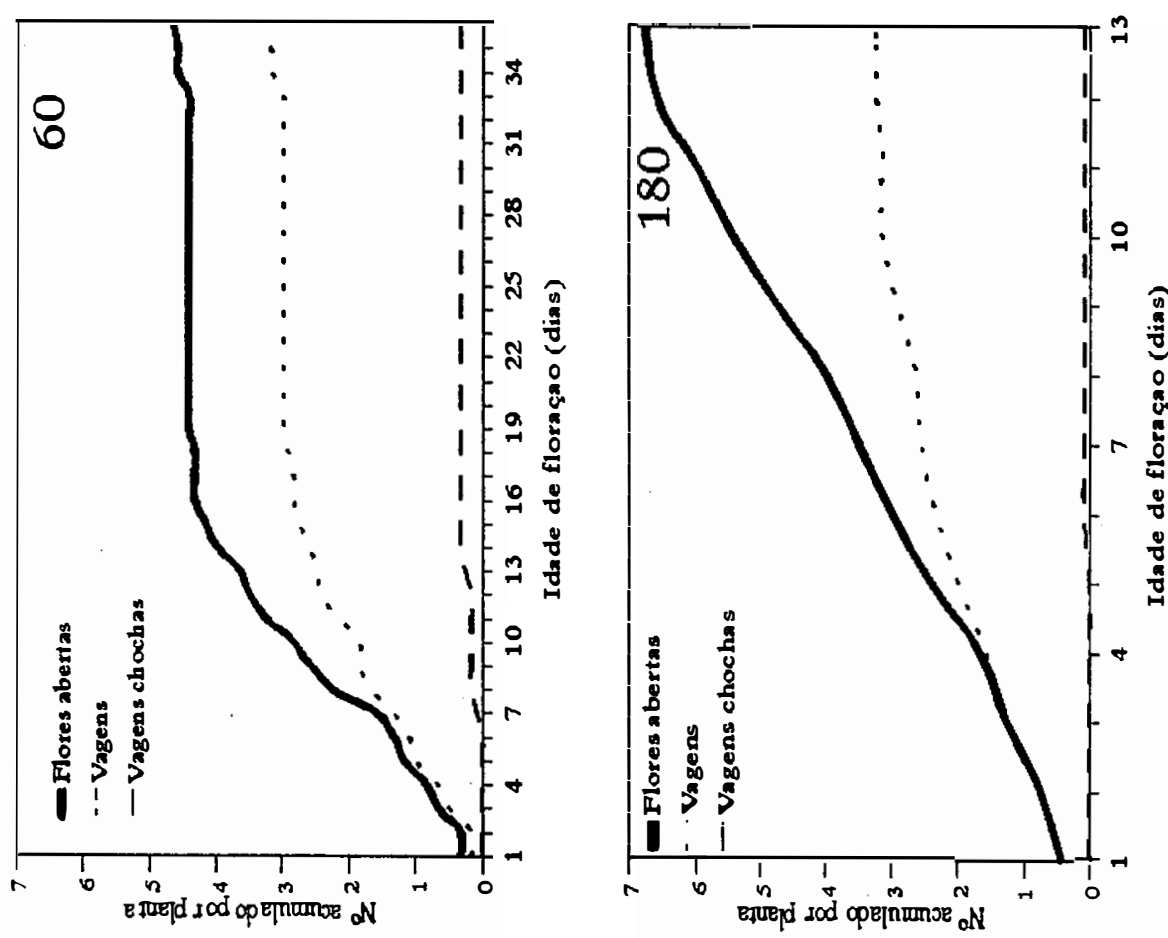

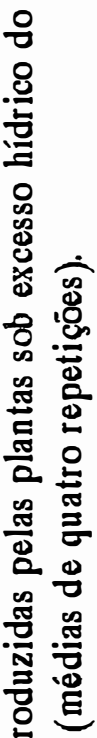
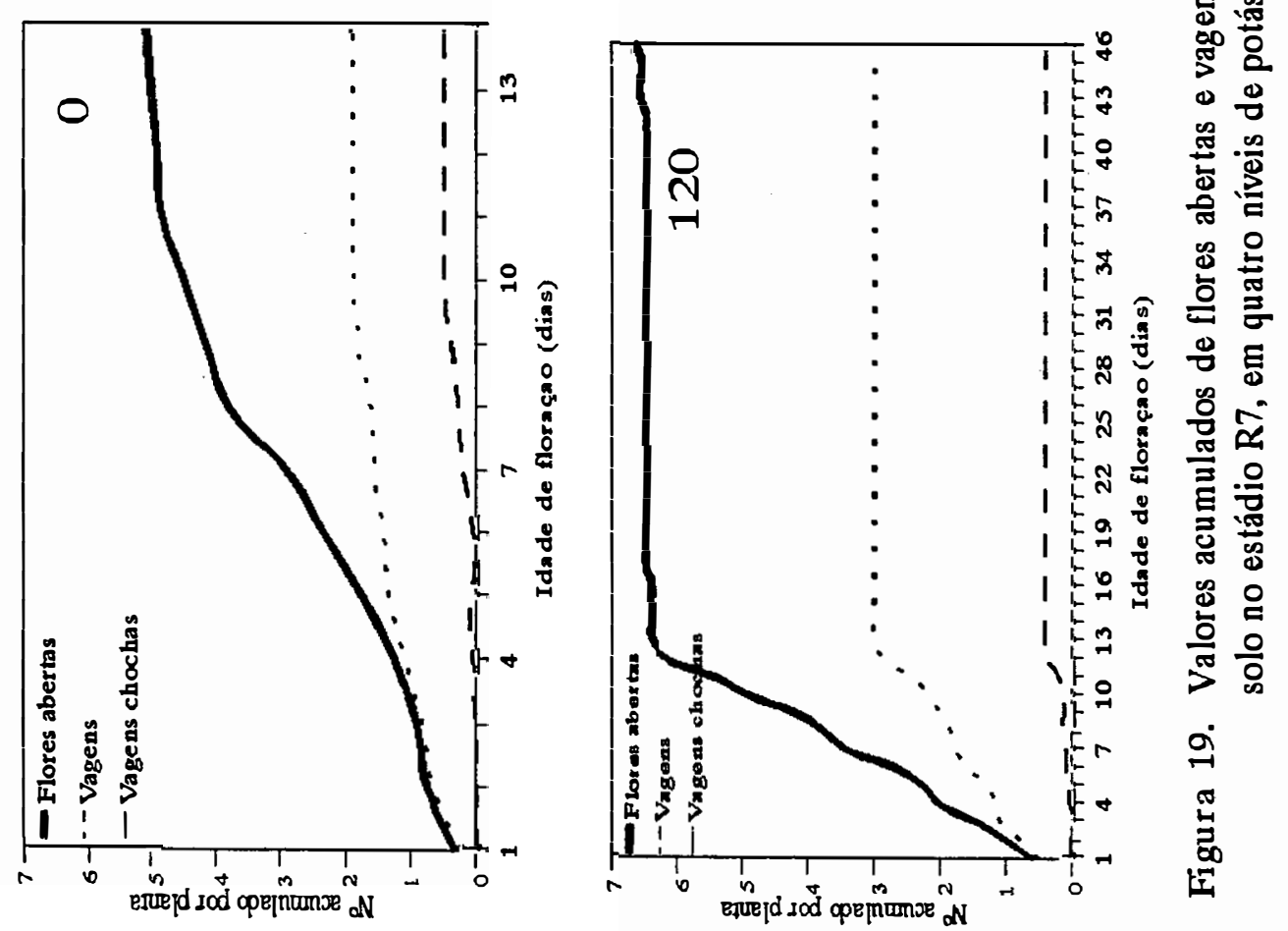
o florescimento tardio em plantas de hábbito indeterminado de crescimento é uma caracrterística agronômica desejável, que possibilita uma certa recuperação das plantas frente a fatores adversos à floração. Em qualquer dos tratamentos em que ocorreu, no entanto, não contribuiu de modo visível para a produção de vagens, que manteve-se constante a partir do $16^{\circ}$ dia do início da floração, com pouco ou nenhum aproveitamento das flores mais tardias.

4.14. Extração de nutrientes pelos grãos

A partir dos resultados da análise química da matéria seca de grãos para N, P, K, Ca, Mg e S calculou-se a extração desses nutrientes pelos grãos (mg/por planta, tabelas $32,33,34,35,36$ e 37 , respectivamente).

o tratamento de deficiência hídrica no solo, em qualquer época, pouco afetou a extração desses nutrientes. Já o tratamento com excesso hídrico na época R5 induziu uma menor extração de nutrientes nos tratamentos com adição de potássio, a partir do nível $60 \mathrm{ppm}$, enquanto que a saturação do solo na época $\mathrm{R7}$ induziu menor extração dos nutrientes a partir da dose 120ppm, exceto para o magnésio. Estes resultados relacionam-se diretamente com o volume de água consumido pelas plantas (tabela 11) que atua nos mecanismos de fluxo de massa e difusão dos nutrientes da solução do solo até as raízes. 
Tabela 32. Extração de nitrogênio pelos grãos (mg/planta), média de quatro repetições.

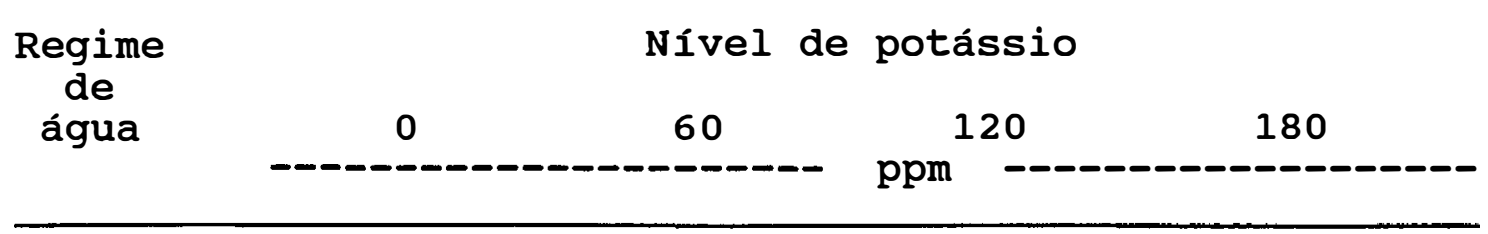

Aplicação de água na época R5

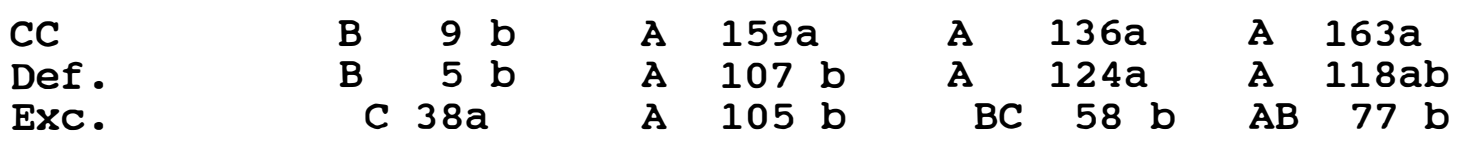

\begin{tabular}{|c|c|c|c|c|c|c|c|c|}
\hline CC & B & $13 a$ & A & $121 a$ & A & $137 a$ & A & $130 a$ \\
\hline Def. & B & $22 a$ & $A$ & $99 a$ & A & $94 \mathrm{ab}$ & A & $97 \mathrm{ab}$ \\
\hline Exc. & B & $24 a$ & $A$ & $89 a$ & A & $88 b$ & A & $80 \mathrm{~b}$ \\
\hline
\end{tabular}

MGdlas antecedidas da mesma letra maluscula na linha ou seguldas da mesma letra minuscula na coluna nao diferem significativamente entre si pelo teste de Duncan, ao nivel de 58 de probabilidade.

Tabela 33. Extração de potássio pelos grãos (mg/planta), média de quatro repetições.

\begin{tabular}{|c|c|c|c|c|}
\hline $\begin{array}{l}\text { Regime } \\
\text { de }\end{array}$ & & vive & Eáss & \\
\hline água & 0 & 60 & 120 & 180 \\
\hline
\end{tabular}

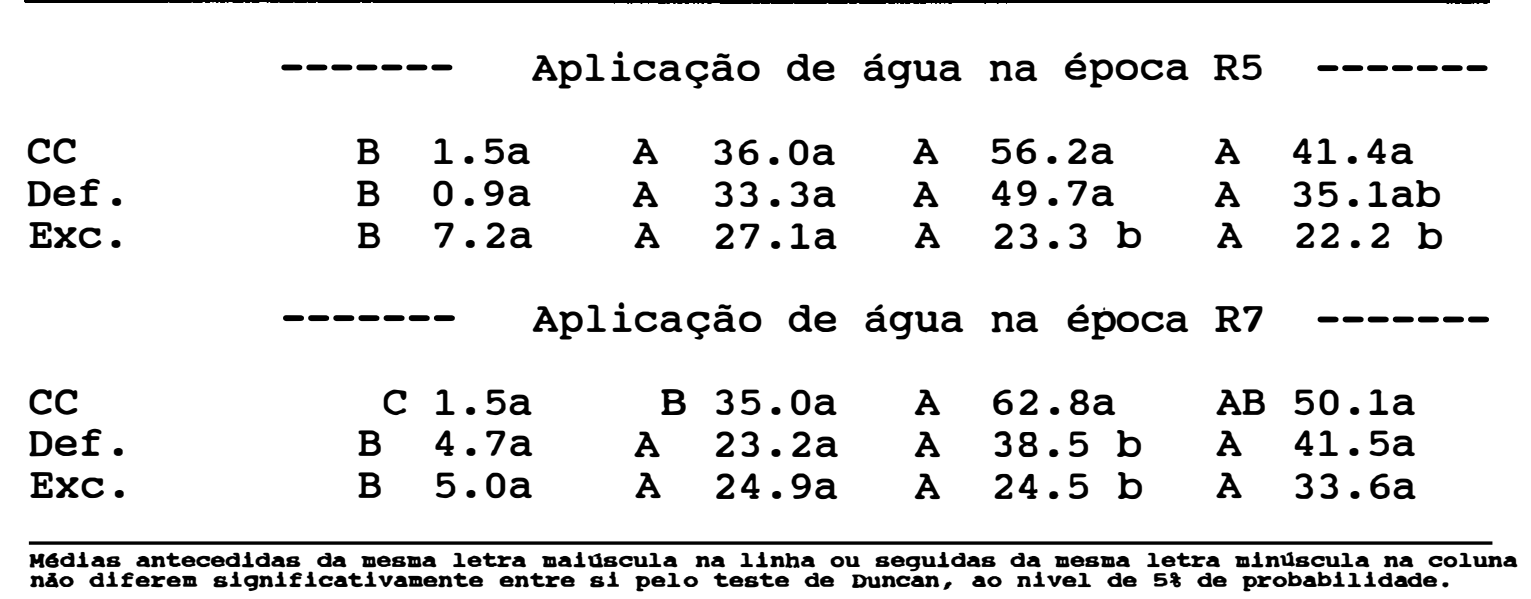


Tabela 34. Extração de fósforo pelos grãos (mg/planta), média de quatro repetições.

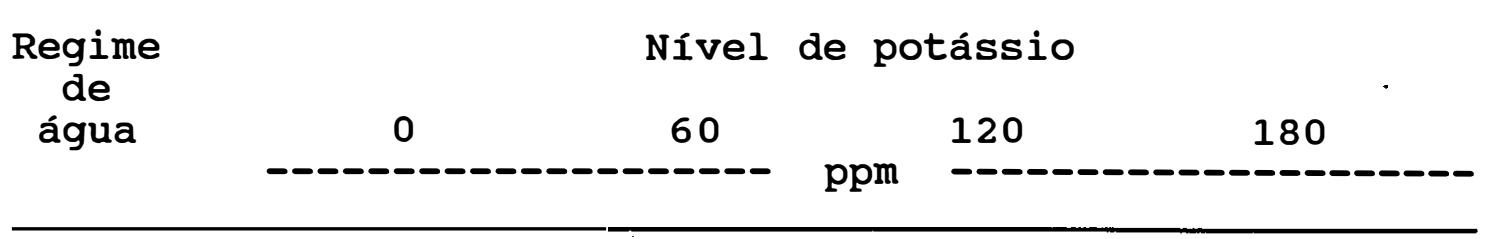

Aplicação de água na época R5

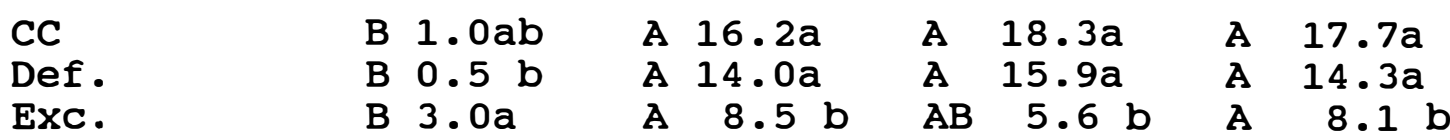

Aplicação de água na época R7

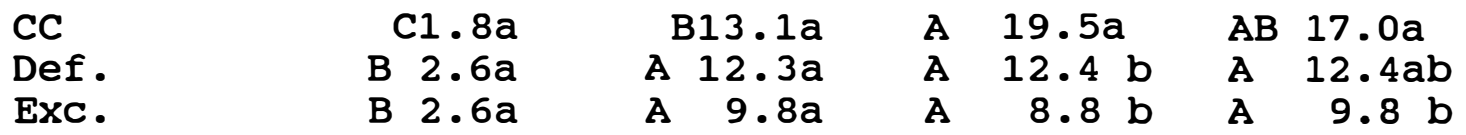

Modlas antecedidas da mesma letra maluscula na linha ou seguldas da mesma letra minuscula na coluna náo diferem significativamente entre si pelo teste de Duncan, ao nivel de $5 \%$ de probabilidade.

Tabela 35. Extração de cálcio pelos grãos (mg/planta), média de quatro repetições.

\begin{tabular}{|c|c|c|c|c|}
\hline $\begin{array}{c}\text { Regime } \\
\text { de }\end{array}$ & & Jíve & Eáss: & \\
\hline água & 0 & 60 & 120 & 180 \\
\hline
\end{tabular}

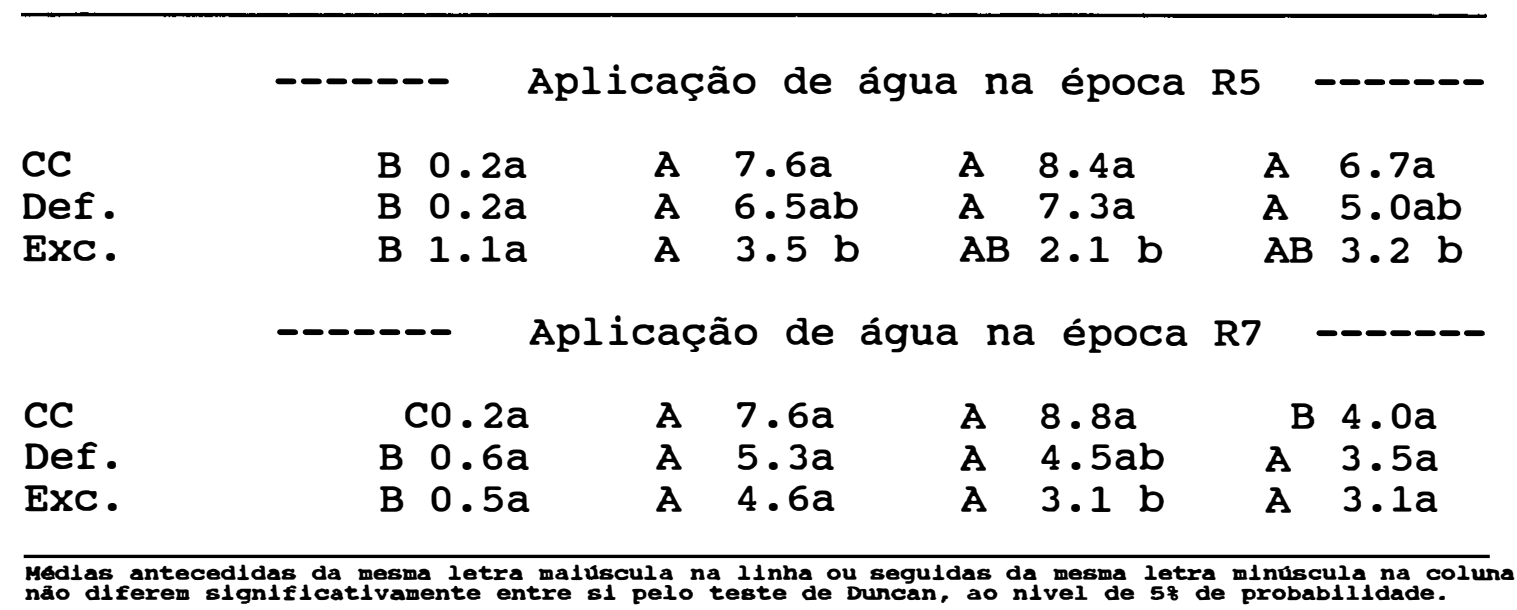


Tabela 36. Extração de magnésio pelos grãos (mg/planta), média de quatro repetições.

\begin{tabular}{|c|c|c|c|c|}
\hline $\begin{array}{c}\text { Regime } \\
\text { de }\end{array}$ & & Vivel & :ássj & \\
\hline água & 0 & 60 & 120 & 180 \\
\hline
\end{tabular}

Aplicação de água na época R5

$\begin{array}{lllllrll}\text { CC } & \text { B } 0.2 b & A & 6.6 a & A & 8.1 a & A & 6.5 a \\ \text { Def. } & \text { B } 0.1 \text { b } & A & 5.6 a b & A & 7.6 a & A & 5.9 a \\ \text { ExC. } & \text { B } 1.5 a & A & 3.5 b & A B & 3.0 b & A & 3.3 b\end{array}$

------- Aplicação de água na época R7

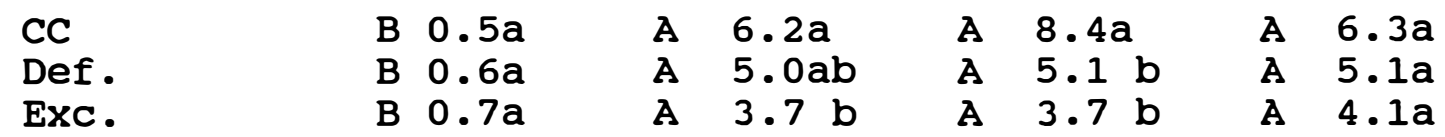

MGdias antecedidas da mesma letra maluscula na linha ou seguldas da mesma letra minuscula na coluna năo diferem significativamente entre si pelo teste de Duncan, ao nivel de 58 de probabilidade.

Tabela 37. Extração de enxofre pelos grãos (mg/planta), média de quatro repetições.

\begin{tabular}{|c|c|c|c|c|}
\hline $\begin{array}{l}\text { Regime } \\
\text { de }\end{array}$ & & Jive & Eáss & \\
\hline água & 0 & 60 & 120 & 180 \\
\hline
\end{tabular}

------ Aplicação de água na época R5 ------

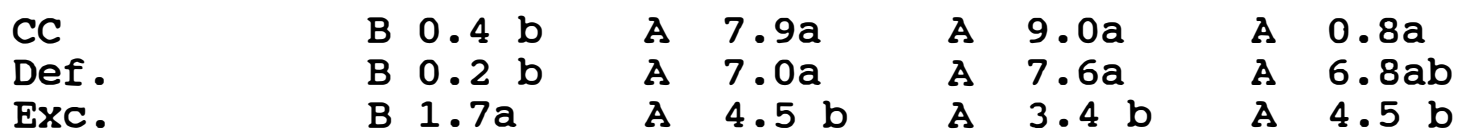

------ Aplicação de água na época $\mathrm{R7}$

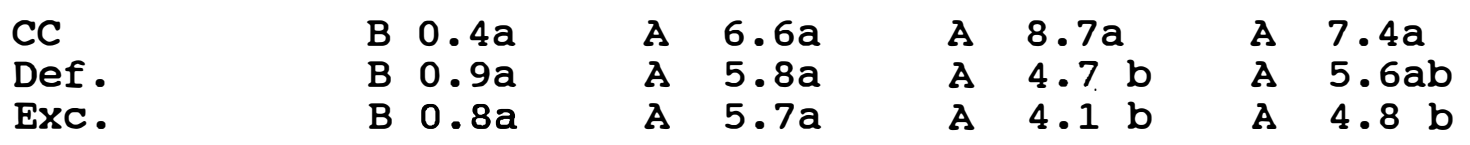

Medias antecedidas da mesma letra maluscula na linha ou seguldas da mesma letra minuscula na coluna

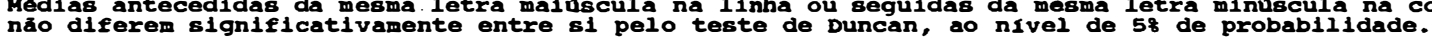


A adubação com potássio aumentou a extração de nutrientes pelos grãos em todos os tratamentos, com resposta quadrática nos três níveis de água (figura 20 e tabela 38), mostrando que a adição do nutriente ao solo favoreceu a translocação dos demais nutrientes até os grãos.

Tabela 38. Equaçōes de regressão e coeficientes de determinação $\left(R^{\wedge} 2\right)$ da extração de nutrientes pelos grãos para as doses de potássio aplicadas ao solo em três regimes de água.

\begin{tabular}{|c|c|c|c|}
\hline $\begin{array}{c}\text { Regime } \\
\text { Nutriente }\end{array}$ & de águ & Equações $1 /$ & $\mathrm{R}^{\wedge} 2$ \\
\hline Nitrogênio & $\begin{array}{l}\text { CC } \\
\text { Def. } \\
\text { Exc. }\end{array}$ & $\begin{array}{l}Y=3,989+0,1414 X-0,000548 X^{\wedge} 2 \\
Y=3,9189+0,1171 X-0,00046 X^{\wedge} 2 \\
Y=5,999+0,0629 X-0,000271 X^{\wedge} 2\end{array}$ & $\begin{array}{l}0,92 \\
0,95 \\
0,74\end{array}$ \\
\hline Fósforo & $\begin{array}{l}\text { CC } \\
\text { Def. } \\
\text { Exc. }\end{array}$ & $\begin{array}{l}Y=1,6229+0,0464 X-0,000178 X^{\wedge} 2 \\
Y=1,6766+0,0397 X-0,000158 X^{\wedge} 2 \\
Y=2,0599+0,0169 X-0,00006 X^{\wedge} 2\end{array}$ & $\begin{array}{l}0,99 \\
0,95 \\
0,76\end{array}$ \\
\hline Potássio & $\begin{array}{l}\text { CC } \\
\text { Def. } \\
\text { Exc. }\end{array}$ & $\begin{array}{l}Y=1,6097+0,0962 X-0,00037 X^{\wedge} 2 \\
Y=1,896+0,0738 X-0,00028 X^{\wedge} 2 \\
Y=2,834+0,0403 X-0,00015 X^{\wedge} 2\end{array}$ & $\begin{array}{l}1,00 \\
0,99 \\
0,88\end{array}$ \\
\hline Cálcio & $\begin{array}{l}\text { CC } \\
\text { Def. } \\
\text { Exc. }\end{array}$ & $\begin{array}{l}Y=1,1809+0,0369 X-0,00016 X^{\wedge} 2 \\
Y=1,2437+0,0275 X-0,00012 X^{\wedge} 2 \\
Y=1,4541+0,0119 X-0,00005 X^{\wedge} 2\end{array}$ & $\begin{array}{l}0,98 \\
0,95 \\
0,68\end{array}$ \\
\hline Magnésio & $\begin{array}{l}\text { CC } \\
\text { Def. } \\
\text { Exc. }\end{array}$ & $\begin{array}{l}Y=1,1997+0,0315 X-0,000129 X^{\wedge} 2 \\
Y=1,228+0,0256 X-0,000102 X^{\wedge} 2 \\
Y=1,456+0,0119 X-0,000046 X^{\wedge} 2\end{array}$ & $\begin{array}{l}0,99 \\
0,98 \\
0,88\end{array}$ \\
\hline Enxofre & $\begin{array}{l}\text { CC } \\
\text { Def. } \\
\text { Exc. }\end{array}$ & $\begin{array}{l}Y=1,245+0,0316 X-0,00012 X^{\wedge} 2 \\
Y=1,3141+0,0256 X-0,000103 X^{\wedge} 2 \\
Y=1,590+0,01307 X-0,00005 X^{\wedge} 2\end{array}$ & $\begin{array}{l}0,98 \\
0,92 \\
0,73\end{array}$ \\
\hline
\end{tabular}

1/ $Y=[\text { quantidade extraída do nutriente (mg/planta) }+1]^{1 / 2}$ $x=$ potássio aplicado ao solo (ppm) 
106.

Considerando-se os nutrientes em conjunto, as maiores extrações ocorreram nas doses variando entre 115 e 141 ppm de potássio aplicado ao solo, nos três níveis de água estudados. Nesse intervalo, obtiveram-se também as melhores respostas para a matéria seca de grãos (figura 14) e matéria seca de raizes (figura 11). A variável matéria seca de raizes na colheita, porém, já está bastante afetada pela senescência, sendo por isso pouco relevante esta relação encontrada. 

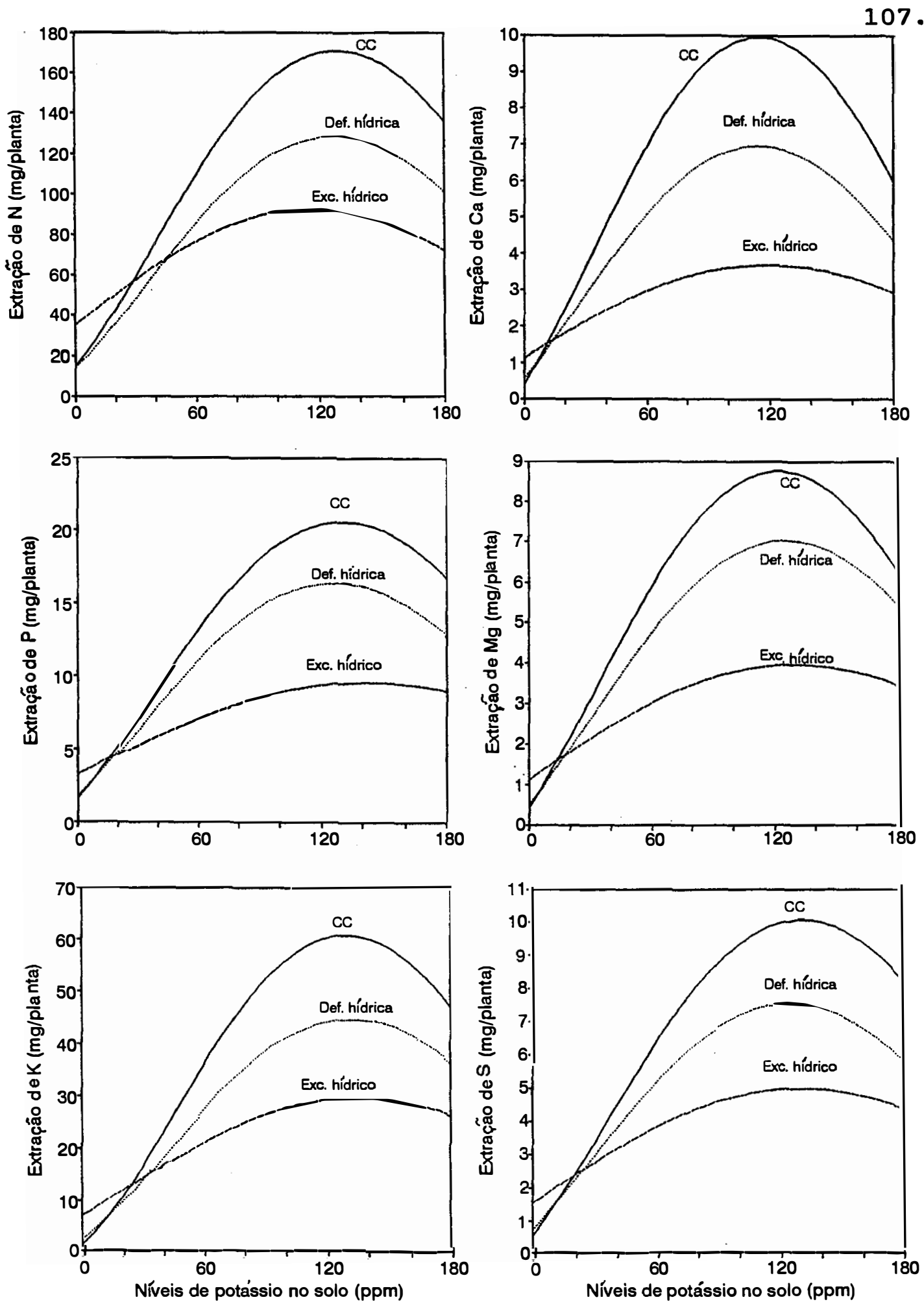

Figura 20. Curvas de regressão da extração de nutrientes pelos grãos de feijoeiro para doses de potássio aplicadas ao solo, em três regimes de água. 
108.

5. CONCLUSÕES

Nas condiçōes em que foi realizado este trabalho, os resultados obtidos permitem estabelecer-se as seguintes conclusões:

- Independente da época em que as plantas foram submetidas aos regimes de água no solo, a dose de potássio aplicada ao solo que proporcionou maior produção de grãos foi próxima de $125 \mathrm{ppm}$, com menores produções nas plantas sob deficiência hídrica no solo, seguidas das plantas sob excesso hidrico no solo;

- A recuperação das plantas sujeitas a curtos períodos de deficiência hídrica no solo foi influenciada pela nutrição potássica;

- o padrão de florescimento e de produção das plantas variou com a nutrição potássica, com os regimes de água e com as épocas de aplicação dos mesmos;

- A sensibilidade das plantas ao excesso de água no solo teve a mesma intensidade nas duas épocas de aplicação do tratamento;

- Plantas no início da frutificação (início do estádio R7) mostraram-se mais sensíveis à deficiência hídrica 
109.

no solo do que plantas no início do pré-florescimento (início do estádio R5):

- Os melhores parâmetros para avaliar plantas sob estresse hídrico foram o número de flores e o número de vagens por planta. 
REFERENCIAS BIBLIOGRÁFICAS

ABDEL RAHMAN, A.A.; SHALAY, A.F.; EL MONAYERI, M.O. Effect of moisture stress on metabolic products and ions accumulations. Plant and Soil, Dordrecht, 34:65-90, 1971.

ACOSTA GALLEGOS, J.A. \& SHIBATA, J.K. Effect of water stress on growth and yield of indeterminate dry-bean (Phaseolus vulgaris) cultivars. Field Crops Research, Amsterdam, 20(2):81-93, 1989 .

ARARIPE, P.A.P. Efeito do estresse hídrico em dois cultivares de feijoeiro (Phaseolus vulgaris, L.). Piracicacaba, 1984. 85p. (Mestrado - Escola Superior de Agricultura "Luiz de Queiroz"/USP).

BEGG, J.E. \& TURNER, N.C. Crop water deficits. Advances in Agronomy, New York, 28:161-217, 1976. 
BENDER, J.; TINGEY, D.T.; JAGER, H.J.; RODECAP, K.D.;

CLARK, C.S. Physiological and biochemical responses of bush bean (Phaseolus vulgaris L.) to ozone and drought stress. Journal of Plant Physiology, Stuttgart, $137(5): 565-70,1991$.

BERGAMASCHI, H.; VIEIRA, H.J.; OMETTO, J.C.; ANGELOCCI, L.R.; LIBARDI, P.L. Deficiência hídrica em feijoeiro. I. Análise de crescimento e fenologia. Pesquisa Agropecuária Brasileira, Brasilia, 23(7):733-43, 1988.

BINKLEY, A.M. The amount of blossom and pod drop on six varieties of garden beans. Proceedings of the American Society for Horticultural Science, New York, 29:489-92, 1932 .

BINNIE, R.C. \& CLIFFORD, P.E. Flower and pod production in Phaseolus vulgaris. Journal of Agricultural Science, Cambridge, 97(2):397-402, 1981.

BOYER, J.S. \& MCPHERSON, H.G. Physiology of water deficits in cereal crops. Advances in Agronomy, New York, 27:123,1975 .

BULISANI, E.A. Crescimento e absorção de nutrientes em cinco cultivares de feijoeiro (Phaseolus vulgaris L.). 
Piracicaba, 1994. 150p. (Doutorado - Escola Superior de Agricultura "Luiz de Queiroz"/USP).

CAIXETA, T.J. Irrigação do feijoeiro. Informe Agropecuário, Belo Horizonte, 4(46):36-40, 1978.

CENTRO INTERNACIONAL DE AGRICULTURA TROPICAL. Una escala de desarrollo para el frijol propone el CIAT. Hojas de Frijol, Cali, $\underline{5}(2): 1-2$, jul. 1983.

CLARK, F.E. \& KEMPER, W.D. Microbial activity in relation to soil water and soil aeration. In: HAGAN, R.M.; HAISE, H.R.; EDMINSTER, T.W., ed. Irrigation of agricultural lands. Madison, American Society of Agronomy, 1974. p.472-80.

Cleland, R. Cell wall extension. Annual Review of Plant Physiology, Palo Alto, 22:197-222, 1971.

COBRA NETO, A.; ACCORSI, W.R.; MALAVOLTA, E. Estudos sobre a nutrição mineral do feijoeiro (Phaseolus vulgaris L., var. Roxinho). Anais da Escola Superior de Agricultura "Luiz de Queiroz", Piracicaba, 28:257-74, 1971 . 
CosTA, M.P. da. Efeito da matéria orgânica em alguns atributos do solo. Piracicaba, 1983. 137p. (Mestrado Escola Superior de Agricultura "Luiz de Queiroz"/USP) •

DASBERG, S. \& BAKKER, J.W. Characterizing soil aeration under changing soil moisture conditions for bean growth. Agronomy Journal, Madison, 62:689-92, 1970.

DATTA, S.C. Simultaneous and intermittent measurement of $\mathrm{K}^{+}, \mathrm{Ca}^{++}$and $\mathrm{NO}^{-}$ion absorption by intact bean plant (Phaseolus vulgaris L.) in aerobic and anaerobic condition. Plant and Soil, Dordrecht, 84(2):193-9, 1985.

DOURADO NETO, D. \& JONG-van-LIER, Q. de. Curvaret; programa computacional. Piracicaba, ESALQ/Depto. de Agricultura, 1992. (Disquete).

DREW, M.C. Early effects of flooding on nitrogen deficiency and leaf chlorosis. New Phytologist, Cambridge, 79:567-71, 1977 .

DREW, M.C. \& SISWORA, E.J. The development of waterlogging damage in young barley plants in relation to plant nutrient status and changes in soil properties. New Phytologist, Cambridge, 82:301-14, 1979 . 
DUBETZ, S. An unusual photonastism induced by drought in Phaseolus vulgaris. Canadian Journal of Botany, Ottawa, $47(10): 1640-1,1969$.

DUBETZ, S. \& MAHALLE, P.S. Effect of soil water stress on bush beans Phaseolus vulgaris L. at three stages of growth. Journal of the American Society for Horticultural Science, Alexandria, 49:479-81, 1969.

EPSTEIN, E. Dual patterns of ion absorption by plant cells and by plants. Nature, London, 212:1324-7, 1966.

FANCELLI, A.L. Fenologia e exigências climáticas do feijoeiro. In: FANCELLI, A.L. \& DOURADO NETO, D., ed. Feijão irrigado. 3.ed. Piracicaba, ESALQ, 1992. p.5-22.

FIEGENBAUM, W. ; SANTOS, D.S.B. dos; MELLO, V.D.C. ; SANTOS FILHO, B.G. dos; TILLMANN, M.A.A.; SILVA, J.B. da. Avaliação da qualidade fisiológica de sementes de feijoeiro submetidas a défice hídrico durante a floração. Pesquisa Agropecuária Brasileira, Brasília, $26(11 / 12): 1885-92,1991$.

FORSYTHE, W.M. \& PINCHINAT, A.M. Tolerancia de la variedad de frijol '27-R' a la inundación. Turrialba, San José, $21: 228-30,1971$. 
GALLO, J.R. \& MIYASAKA, S. Composição química do feijoeiro e absorção de elementos nutritivos do florescimento à maturação. Bragantia, Campinas, 20:867-84. 1961 .

GENUCHTEN, M.T. van. A closed-form equation for predicting the hydraulic conductivity of unsaturated soils. Soil Science Society of America Journal, Madison, 41:892-8, 1980 .

GLINSKI, J. \& STEPNIEWSKI, W. Soil aeration and its role for plants. Boca Raton, CRC Press, 1986. 229p.

GOLDSWORTHY, P.R. Crop growth and development: the reproductive phase. In: GOLDSWORTHY, P.R. \& FISHER, N.M., ed. The physiology of tropical field crops. Chichester, John Wiley, 1984. p.119-61.

HEGDE, D.M \& SRINIVAS, K. Plant water relations and nutrient uptake in French bean. Irrigation Science, Berlin, 11(1):51-6, 1990 .

HOLDER, C.B. \& BROWN, K.W. The relationship between oxygen and water uptake by roots of intact bean plants. Soil Science Society of America Journal, Madison, 44:21-5, 1980. 
hostalÁCIO, S. \& VÁlio, I.F.M. Desenvolvimento dos frutos de feijão em diferentes regimes de irrigação. Pesquisa Agropecuária Brasileira, Brasilia, 19(1):53-7, 1984 .

HSIAO, T.C. Plant responses to water stress. Annual Review of Plant Physiology, Palo Alto, 24:519-70, 1973.

KATTAN, A.A. \& FLEMING, J.M. Effect of irrigation at specific stages of development on yield, quality, growth and composition of snap beans. Proceedings of the American Society for Horticultural Science, New York, $68: 329-42,1956$

KIEHL, E.J. Manual de edafologia; relações solo-planta. São Paulo, Ceres, 1979. 262p.

KONSENS, I.; OFIR, M.; KIGEL, J. The effect of temperature on the production and abscission of flowers and pods in snap bean (Phaseolus vulgaris L.). Annals of Botany, London, 67(5):391-9, 1991 .

KRAMER, P.J. Water relations of plants. New York, Academic Press, 1983. 489p. 
LAING, D.R.; JONES, P.G.; DAVIS, H.C. Common bean (Phaseolus vulgaris L.) . In: GOLDSWORTHY, P.R. \& FISHER, N.M., ed. The physiology of tropical field crops. Chichester, John Wiley, 1984. p.305-51.

LAKITAN, B. Morphological and some physiological responses of bean (Phaseolus vulgaris L.) to flooding. Dissertation Abstracts International. Sciences and Engineering, $50(9): 3793 B, 1990$.

LAKITAN, B. \& WOLFE, D.W. Yield and growth suppressions in flooded snap bean (Phaseolus vulgaris L.) as related to plant age. HortScience, Alexandria, 23(3):780-99, 1988.

LAKITAN, R.; WOLFE, D.W.; ZOBEL, R.W. Flooding affects snap bean yield and genotypic variation in leaf gas exchange and root growth response. Journal of the American Society for Horticultural Science, Alexandria, $117(5): 711-6,1992$.

LAWN, R.J. Response of four grain legumes to water stress in South-Eastern Queensland. III. Dry matter production, yield and water use efficiency. Australian Journal of Agricultural Research, Melbourne, 33:511-21, 1982.

LEGARDA, L. \& FORSYTHE, W. Soil water and aeration and red 
bean production. II. Effect of soil aeration. Turrialba, San José, 28(3):175-8, 1978 .

LETEY, J.; STOLZY, L.H.; BLANK, G.B. Effect of duration and timing of low soil oxygen content on shoot and root growth. Agronomy Journal, Madison, 54:34-7, 1962.

LOPES, N.F.; OLIVA, M.A.; CARDOSO, M.J.; GOMES, M.M.S.; SOUZA, V.F. de. Crescimento e conversão da energia solar em Phaseolus vulgaris L. submetido a três densidades de fluxo radiante e dois regimes hidricos. Revista Ceres, Viçosa, 33(186):142-64, 1986.

LOPES, N.F.; OLIVA, M.A.; GOMES,M.M.S.; SOUZA, V.F. de; CARDOSO, M.J. Crescimento, morfologia, partição de assimilados e produção de matéria seca do feijão (Phaseolus vulgaris L.) submetido a três densidades do fluxo radiante e dois regimes hídricos. Revista Ceres, Viçosa, 34(192):110-24, 1987 .

MACK, H.J. \& SINGH, J.N. Effects of high temperature on yield and carbohydrate composition of bush snap beans. Journal of the American Society for Horticultural Science, Alexandria, 94:60-2, 1969. 
MAGALHÃES, A.A. de \& MILLAR, A.A. Efeito do déficit de água no período reprodutivo sobre a produção do feijão. Pesquisa Agropecuária Brasileira, Brasília, 13(2):55-60, 1978 .

MAGALHÃES, A.A. de; MILLAR, A.A.; CHOUDHURY, E.N. ; CHOUDHURY, M.M. Efeito do déficit fenológico de água sobre a produção do feijão. Turrialba, San José, 29(4):269-73, 1979 .

MENGEL, K. Fatores e processos que afetam as necessidades de potássio das plantas. In: YAMADA, T.; IGUE, K.: MUZILI,O.; USHERWOOD, N.R., ed. Potássio na agricultura brasileira. Piracicaba, Instituto da Potassa \& Fosfato/Instituto Internacional da Potassa, 1982. p.195212 .

MENGEL, K. \& ARNEKE, W.W. Effect of potassium on the water potential, the pressure potential, the osmotic potential and cell elongation in leaves of Phaseolus vulgaris L. Physiologia Plantarum, Copenhagen, 54(4):402-8, 1982..

MENGEL, K. \& KIRKBY, E.A. Principles of plant nutrition. 4.ed. Bern, International Potash Institute, 1987. 687p. 
MUIRHEAD, W.A. \& WHITE, J.G. The influence of soil water potential on the flowering pattern, pod set and yield of snap bean (Phaseolus vulgaris L.). Irrigation Science, Berlin, 3(1):45-56, 1981 .

NEUMAN, D.S. \& SMIT, B.A. The influence of leaf water status and ABA on leaf growth and stomata of Phaseolus seedlings with hypoxic roots. Journal of Experimental Botany, Oxford, 42(245):1499-506, 1991 .

OZBUN, J.L.; VOLK, R.J.; JACKSON, W.A. Effects of potassium deficiency on photosynthesis, respiration and the utilization of photosynthetic reductant by mature bean leaves. Crop Science, Madison, 5:497-500, 1965.

PEASLEE, D.E. \& MOSS, D.N. Stomatal conductivities in Kdeficient leaves of maize (Zea mays L.). Crop Science, Madison, 8(1):427, 1968 .

PORTES, T.A. Manual de métodos de pesquisa em feijão: parâmetros fisiológicos e agronômicos comumente empregados na pesquisa com feijão (Phaseolus vulgaris L.) . Suplemento I. Goiânia, EMBBRAPA-CNPAF, 1981. 22p. 
PORTES, T.A. Ecofisiologia. In: ZIMMERMANN, M.J.O. \& YAMADA, T., ed. Cultura do feijoeiro: fatores que afetam a produtividade. Piracicaba, Associação Brasileira para Pesquisa da Potassa e do Fosfato, 1988. p.125-56.

RAGGI, L.A.; BERNARDO, S.; GALVÃO, J.D. Efeito do turno de rega em três fases do ciclo do feijoeiro. Seiva, Viçosa, 32(76):35-42, 1972 .

RAIJ, B. van. Avaliação da fertilidade do solo. Piracicaba, Instituto da Potassa \& Fosfato, Instituto Internacional da Potassa, 1981. 142p.

RAIJ, B. van \& QUAGGIO, J.A. Métodos de análise de solo para fins de fertilidade. Campinas, Instituto Agronômico, 1983. 31p. (IAC. Boletim Técnico, 81).

RAIJ, B. van; SILVA, N.M.; BATAGLIA, O.C.; QUAGGIO, J.A.; HIROCE,R.; CANTARELLA, H.; BELLINAZZI JÚNIOR,R.; DECHEN, A.R.; TRANI, P.E. Recomendações de adubação e calagem para o Estado de São Paulo. Campinas, Instituto Agronômico, 1985. 107p. (IAC. Boletim Técnico, 100).

RAMALHO, M.A.P. \& FERREIRA, M.M. Comportamento de cultivares de feijão (Phaseolus vulgaris L.) em relação 
ao florescimento e vingamento das vagens. Ciência e Prática, Lavras, 3:80-4, 1979.

RANZANI, G.; FREIRE, O.; KINJO, T. Carta de solos do município de Piracicaba. Piracicaba, ESALQ, 1966. 85p.

ROBINS, J.S. \& DOMINGO, C.E. Moisture deficits in relation to the growth and development of dry beans. Agronomy Journal, Madison, 48(2):67-70, 1956 .

ROSOLEM, C.A. A adubação do feijoeiro sob irrigação. In: FANCELLI, A.L. \& DOURADO NETO, D. , ed. Feijão irrigado. 3.ed. Piracicaba, ESALQ, 1992. p.46-81.

SARRUGE, J.R. \& HAAG, H.P. Análises químicas em plantas. Piracicaba, ESALQ, 1974. 55p.

SARTORATO, A. Principais doenças da parte aérea do feijoeiro comum e seus controles. In: FANCELLI, A.L. \& DOURADO NETO, D., ed. Feijão irrigado. 3.ed. Piracicaba, ESALQ, 1992. p.102-16.

SARTORATO, A.; ANTUNES, I.F.; KLUTHCOUSKI, J.; ROCHA, J.A.M.; TEIXEIRA, M.G.; YOKOYAMA, M.; SILVEIRA, P.M. da; GUAZZELLI, R.J. Sistema de produção para cultivo de feijão no inverno. Goiânia, EMBRAPA/CNPAF, 1981. 21p. 
(EMBRAPA/CNPAF. Circular Técnica, 12).

SCHRAVENDIJK, H.W. van \& ANDEL, O.M. van. Interdependence of growth, water relations and abscisic acid level in Phaseolus vulgaris during waterlogging. Physiologia Plantarum, Copenhagen, 63(2):215-20, 1985.

SILVA, E.L. da. Suscetibilidade do feijoeiro (Phaseolus vulgaris L.) cv. Goiano Precoce, a inundações temporárias do sistema radicular em diferentes fases do seu ciclo vegetativo. Piracicaba, 1982. 77p. (Mestrado - Escola Superior de Agricultura "Luiz de Queiroz"/USP).

SILVA, H.T. da. Caracteri zação morfológica, agronômica e fenológica de cultivares de feijão (Phaseolus vulgaris L.) comumente plantadas em diversas regiões do Brasil. Goiânia, EMBRAPA/CNPAF， 1981. 51p. (EMBRAPA/CNPAF. Circular Técnica, 15).

SILVEIRA, P.M.; CASTRO, T.A.P.; STONE, L.F. Idade de flOração e vingamento de flores em duas cultivares de feijão. Pesquisa Agropecuária Brasileira, Brasília, $15(2): 229-32$, 1980 . 
SILVEIRA, P.M.; GUIMARÃES, C.M.; STONE, L.F.; KLUTHCOUSKI, J. Avaliação de cultivares de feijão para resistência à seca baseada em dias de estresse de água no solo. Pesquisa Agropecuária Brasileira, Brasília, 16(5):693-9, 1981.

SINGH, B.P.; TUCKER, K.A.; SUTTON, J.D.; BHARDWAJ, H.L. Flooding reduces gas exchange and growth in snap bean. HortScience, Alexandria, 26(4):372-2, 1991.

SMITH, F.L. \& PRYOR, R.H. Effects of maximum temperature and age on flowering and seed production in three bean varieties. Hilgardia, Berkeley, 33(12):669-88, 1962.

SOJKA, R.E. \& STOLZY, L.H. Soil-oxygen effects on stomatal response. Soil Science, Baltimore, 130(6):350-8, 1980 .

STONE, L.F.; PORTES, T.A.; MOREIRA, J.A.A. Efeitos da tensão da água do solo sobre a produtividade e crescimento do feijoeiro. II. Crescimento. Pesquisa Agropecuária Brasileira, Brasilia, 23(5):503-10, 1988.

SUBHADRABANDHU, S.; ADAMS, M.W.; REICOSKY, D.A. Abscission of flowers and fruits in Phaseolus vulgaris L. I. Cultivar differences in flowering pattern and abscission. Crop Science, Madison, 18(5):893-6, 1978 . 
125.

THOMAS, R.J. \& HUNGRIA, M. Effect of potassium on nitrogen fixation, nitrogen transport and nitrogen harvest index of bean. Journal of Plant Nutrition, New York, $11(2): 175-88,1988$

TURNER, N.C. \& BEGG, J.E. Plant-water relations and adaptation to stress. Plant and Soil, Dordrecht, 58 $(1 / 3): 97-131,1981$.

VENDRAMIM, J.D. Pragas da cultura de feijão irrigado. In: FANCELLI, A.L. \& DOURADO NETO, D., ed. Feijão irrigado. 3.ed. Piracicaba, ESALQ, 1992. p.82-91.

VIETS Jr., F.G. Water deficits and nutrient availability. In: KOZLOWSKI, T.T., ed. Water deficits and plant growth. New York, Academic Press, 1972. v.3, p.217-39.

VILHORDO, B.W.; BURIN, M.E.; GANDOLFI, V.H. Morfologia. In: ZIMMERMANN, M.J.O. \& YAMADA, T., ed. Cultura do feijoeiro: fatores que afetam a produtividade. Piracicaba, Associação Brasileira para Pesquisa da Potassa e do Fosfato, 1988. p.87-123. 
WEAVER, M.L.; NG, H.; BURKE, D.W.; SILBERNAGEL, M.J.:

FOSTER, K.; TIMM, H. Effect of soil moisture tension

on pod retention and seed yield of bean. Horticultural Science, Alexandria, 19(4):567-9, 1984 .

WOLF, B. Chemical factors influencing the set of Henderson Lima beans. Journal of the American Society of Agronomy, Alexandria, 34:646-50, 1942. 